\title{
PRODUÇÃO DE SEMENTES DE CULTIVARES PRECOCES DE SOJA, HM DIFERENTES ÉPOCAS \\ E IOCAIS DO ESTADO DE SÃO PAULO
}

PRISCILA FRATIN MEDINA

Engenheiro Agrônomo

Orientador: Prof. Dr. Júlio Marcos Filho

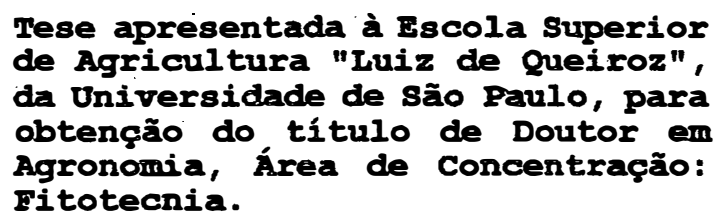


Ficha catalagrafica preparada pela Secáa de Livros da Divisão de Biblioteca e Documentaçă - FCLQ/USP

\footnotetext{
Medina, Friscila Fratin

M491p Froducaro de sementes de cultivares precoces de soja, em diferentes epocas e locais do Estado de Săo Faulo. Firacicaba, 1994.

173 P. ilus.
Tese - EsalQ
Bitliografia

1. Semente - Qualidade 2. Soja - Epoca de semeadura 3. Soja - Semente - Froduçaro I. Escola Superior de Agricultura Luiz de Queiroz, Piracicaba
}

CDD 633.34 


\section{PRODUÇÃO DE SEMENTES DE CULTIVARES PRECOCES DE SOJA, EM DIFERENTES EPOCAS E LOCAIS DO ESTADO DE SÃO PAULO}

PRISCIIA FRATIN MEDINA

Aprovada em: 08.04.94

Comissão julgadora:

Prof. Dr. Júlio Marcos Filho ESALQ/USP Dr. Luiz Fernandes Razera IAC Prof. Dr. Roberval Daiton Vieira FCAVJ/UNESP Prof. Dr. Rubens Sader FCAVJ/UNESP Prof. Dr. Sílvio Moure Cícero ESALQ/USP

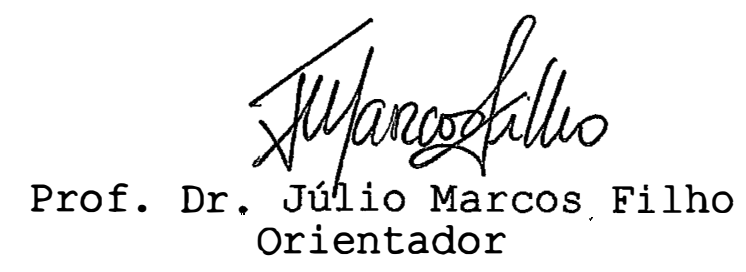


Ao meu marido Camilo, aos meus filhos Rodrigo e Guilherme, à minha mãe Liliana, pelo apoio e estímulo. 


\section{AGRADECIMENTOS}

Ao Prof. Dr. Júlio Marcos Filho, pela dedicada orientação durante todas as fases do curso.

Ao Pesquisador Dr. Luiz Fernandes Razera, pela valiosa colaboração, apoio e facilidades proporcionadas.

Aos Pesquisadores Drs. Nelson Bortoletto e Otávio Tisselli Filho, pelas colaborações prestadas durante a condução dos ensaios de campo, respectivamente, na Estação Experimental de Votuporanga e Centro Experimental de Campinas, do Instituto Agronômico.

Aos Pesquisadores Drs. Carlos Jorge Rossetto e Jaciro Soave pelas valiosas sugestões.

Ao Pesquisador Dr. Toshio Igue pela orientação no planejamento e execução da análise estatística.

Às Engenheiras Agrônomas Ana Dionísia L.C. Novembre e Helena Maria P. Chamma pela atenção e colaboração prestadas durante a condução do teste de condutividade elétrica, no Laboratório de Análise de Sementes, do Departamento de Agricultura da ESALQ. 
À Engenheira Agrônoma Flávia R.A. Patrício pela colaboração prestada durante a condução dos testes de sanidade das sementes, no Laboratório de Sementes da Coordenadoria de Assistência Técnica Integral - CATI.

Aos Funcionários do Sistema de Produção de Sementes do Instituto Agronômico, em especial ao Dirceu Borges, à Maria das Graças dos Santos Lima e à Deliane de Oliveira pelas colaborações prestadas, durante a execução desse trabalho.

Ao Instituto Agronômico do Estado de São Paulo, pela oportunidade e suporte fornecidos para a realização do curso de pós-graduação.

Aos Professores e Funcionários, do Departamento de Agricultura da ESALQ.

Aos Colegas do curso pela amizade e incentivo.

A Todos aqueles que, de alguma forma, contribuíram para que este trabalho pudesse ser realizado. 
SUMÁRIO

Página

RESUMO

viii

SOMMARY

xi

1. IRTRODUÇÃO

2. REVISÃO DE LITERATORA

2.1. Produção de Sementes

2.1.1. Fotoperíodo

2.1.2. Temperatura

2.1.3. Disponibilidade hídrica

2.2. Qualidade Fisiológica da Semente . . . . . 13

2.3. Sanidade da Semente... . . . . . . . 20

2.3.1. Fungos . . . . . . . . . . . . 20

2.3.2. Insetos . . . . . . . . . . . 29

3. MATERIAL E MÉTODOS . . . . . . . . . . . . 32

3.1. Sementes e cultivares........... . 32

3.2. Ensaios de Campo . . . . . . . . . . . 33

3.3. Avaliação da Qualidade das Sementes . . . . . 44

3.3.1. Peso de mil sementes. . . . . . . . . 44

3.3.2. Grau de umidade . . . . . . . . . . . 47

3.3.3. Germinação . . . . . . . . . . . . 47

3.3.4. Envelhecimento artificial . . . . . 47

3.3.5. Condutividade elétrica . . . . . . . 48

3.3.6. Tetrazólio . . . . . . . . . . . 48

3.3.7. Sanidade . . . . . . . . . . . . . 49

3.3.7.1. Teste do papel de filtro . . 49

3.3.7.2. Avaliações visuais . . . . 50 
3.4. Teste de Energência de Plântulas . . . . . . 50

3.5. Produção de Sernentes viáveis . . . . . . . . 50

3.6. Procedimento Estatístico . . . . . . . . 51

4. RESUltados E discUSSÃo . . . . . . . . . . . 53

4.1. Fenologia . . . . . . . . . . . . . 53

4.2. Características Agroßômicos . . . . . . . . 58

4.2.1. Altura das plantas... . . . . . 60

4.2.2. Número de nós por planta . . . . . . 63

4.2.3. Altura da inserção da primeira vagem . 66

4.2.4. Número de vagens por planta . . . . 68

4.2.5. Peso de mil sementes... . . . . . 70

4.3. Produção de Serbentes . . . . . . . . . . . . 74

4.4. Qualidade Fisiológica das Sementes . . . . . 78

4.5. Sanidade das Sementes .. . . . . . . . . 103

4.5.1. Sementes atacadas por insetos-percevejos 103

4.5.2. Sementes infectadas pol: fungos . . . 107

4.5.3. Sementes com mancha caifé . . . . . . 142

4.6. Produção de Sementes Viáveis . . . . . . . 142

4.7. Considerações Finais . . . . . . . . . . . . 148

5. conclusões . . . . . . . . . . . . . . . . . 152

REFERÊNCIAS BIBLIOGRÁFICAS . . . . . . . . . . 154 
PRODUÇÃO DE SEMENTES DE CULTIVARES PRECOCES DE SOJA, FM DIFERENTES ÉPOCAS E IOCAIS DO ESTADO DE SÃO PAULO

Autora: PRISCILA FRATIN MEDINA Orientador: PROF. DR. JÚLIO MARCOS FILHO

\section{RESUMO}

Com o objetivo de verificar a possibilidade de produção de sementes de cultivares precoces de soja (Glycine max (L.) Merrill) na estação seca, sob irrigação suplementar e de obter informações sobre a qualidade das sementes produzidas, foram realizadas duas semeaduras, a primeira na época convencional (novembro de 1989) e a segunda no final do verão/início do outono, em dois municípios do Estado de São Paulo: Campinas (latitude $22^{\circ} 54^{\prime} \mathrm{S}$ e longitude 47\%5'W.Grw.) e Votuporanga (latitude $20^{\circ} 25^{\prime} \mathrm{S}$ e longitude $49^{\circ} 59^{\prime}$ W.Grw. ). Para tanto, empregaram-se as sementes dos cultivares 'IAC-100', 'IAC-16', 'IACFoscarin-31', 'BR-4' e 'IAS-5' .

Quando as plantas atingiram o estádio de desenvolvimento R8 (noventa e cinco por cento das vagens com coloração padrão do respectivo cultivar), as seguintes 
características agronômicas foram avaliadas: altura das plantas, número de nós por planta, altura da inserção das primeiras vagens e número de vagens por planta. o peso de mil sementes e a produção total foram avaliados após a colheita.

A qualidade das sementes foi determinada em duas épocas, uma conduzida após a colheita e a outra, na ocasião em que seria efetuada a semeadura seguinte (novembro de 1990), utilizando-se os testes de germinação, envelhecimento artificial, condutividade elétrica, tetrazólio 1-5, tetrazólio 1-3, além de testes de sanidade. Nestas oportunidades, realizaram-se os cálculos de produção de sementes viáveis. Três testes de emergência de plântulas em campo também foram conduzidos, quinzenalmente, nos meses de novembro e dezembro de 1990.

A análise dos dados e a interpretação dos resultados do presente trabalho permitiram concluir que:

a) o retardamento da semeadura de cultivares precoces de soja para o final do verão/início do outono, associado à condução da cultura sob irrigação suplementar, constitui-se alternativa viável para a produção de sementes de melhor qualidade;

b) a redução da produtividade da cultura, resultante de retardamento da época de semeadura, é compensada pela maior possibilidade de obtenção de sementes de cultivares precoces de soja de melhor qualidade fisiológica e sanitária; 
c) a adoção de retardamento da semeadura, na produção de sementes de cultivares precoces de soja, deve ser baseada na análise tanto da produção total como na de sementes viáveis, considerando-se a época de avaliação da qualidade das sementes;

d) as diferenças de qualidade das sementes são determinadas pelos efeitos de temperatura e umidade relativa do ar, e de patógenos, predominantes em cada época e local, no período que coincide com a maturação e a colheita das sementes. 
SEED PRODUCTION OF EARLY MATURING SOYBEAN CULTIVARS, IN DIFETRENT PLANTING DATES AND IOCATIONS OF SÃO PAULO STATE, BRASIL

Author: PRISCILA FRATIN MEDINA Adviser: PROF. DR. JÚLIO MARCOS FILHO

SUMRARY

The objective of this research was to study the possibility of producing high quality seeds of early maturing soybean (Glycine max (L.) Merrill) cultivars at the dry season using irrigation.

The experiments were grown in São Paulo State, Brazil, under field conditions at Campinas $\left(22^{\circ} 54^{\prime} \mathrm{S}\right.$ latitude and $47^{\circ} 5^{\prime}$ W.Gr. longitude), and at Votuporanga (20²5's latitude and 49.59' W.Gr. longitude).

Soybean cultivars 'IAC-100', 'IAC-16', 'IACFoscarin-31', 'BR-4' and 'IAS-5' were sown in two planting dates: the first one at the traditional time (november 1989) and the second at the end of summer/beginning of autumn (1990). 
The following yield components were evaluated at harvest maturity (R8 stage) plant height, number of nodes per plant, first pod insertion height and number of pods per plant. Weight of 1,000 seeds and yield were determined after harvest.

Seed quality evaluations consisted of the following tests: germination, accelerated aging, electrical conductivity, tetrazolium 1-5, tetrazolium 1-3 and seed health. All tests were conducted in two periods, one after harvest and the other one at the time of next sowing (november 1990). Calculations of pure live seeds yield were also done at these times. Furthermore, three seedling field emergence tests were sown in november and december, 1990. Analysis of the data and interpretation of the results led to the following conclusions:

a) delaying sowing of early maturing soybean cultivars until the end of summer/beginning of autumn, and growing the crop under irrigation is viable for producing high quality seeds;

b) yield reduction verified as the sowing is delayed until the end of summer/beginning of autumn is compensated by greater possibility of harvesting soybean seeds showing better physiological quality and health.

c) the adoption of delaying sowing to produce seeds of early maturing soybean cultivars must be based on yield and viable seeds yield analysis, considering the time when seed quality is evaluated; 
xiii

d) differences in seed quality are determined by air temperature, humidity and pathogens effects, predominating during the period of seed maturation and harvest date. 


\section{INTRODUÇÃO}

No Estado de São Paulo, mormente para cultivares precoces, a maturação e a colheita da soja produzida na época convencional de semeadura (outubro/novembro) freqüentemente ocorre sob condições climáticas desfavoráveis, caracterizadas por temperatura e umidade relativa do ar elevadas. Conseqüentemente, as sementes apresentam baixa qualidade, não atingindo a época de semeadura seguinte com índices de germinação desejáveis.

Esta dificuldade pode ser solucionada pela pesquisa e um caminho, talvez o mais apropriado e de solução mais rápida, é a semeadura em época que possibilite a coincidência da maturação e colheita com períodos climáticos mais favoráveis.

O retardamento da semeadura para dezembro e início de janeiro pode proporcionar obtenção de sementes de soja de melhor qualidade fisiológica e sanitária. Este procedimento, no entanto, dificulta a utilização da terra quando se deseja cultivar mais de uma cultura no mesmo ano agrícola com semeadura entre agosto e outubro, culminando com a colheita no mês de dezembro, pois haveria um curto 
espaço de tempo para o preparo da área entre a colheita da safra anterior e a semeadura da soja. Isto poderia ainda ser agravado, considerando-se as condições climáticas de intensa pluviosidade, desfavoráveis ao preparo do solo, predominantes no mês de dezembro.

Em face a esta situação, este trabalho foi desenvolvido com os seguintes objetivos:

- Verificar a possibilidade de produção de sementes de cultivares precoces de soja em duas regiões do Estado de São Paulo, na estação seca (semeadura em março/abril), sob irrigação suplementar.

- Reunir informações sobre a qualidade das sementes produzidas na estação seca, em comparação às obtidas na época convencional. 


\section{REVISÃO DE LITERATURA}

\subsection{Produção de Sementes}

Pesquisas realizadas no Brasil, principalmente a partir da década de 70 e nos Estados Unidos, há mais tempo, demonstraram que a época de semeadura é a variável que produz maior impacto sobre a produção da cultura da soja (DIMMOCK \& WARREN, 1953; HAR'I'WIG, 1954; BUENO et al., 1975; BARNI et al., 1978; MILANEZ et al., 1978; COSTA et al., 1979; NAKAGAWA et al., 1983 e BOARD, 1987) .

Vários são os fatores que condicionam a escolha da época de semeadura. Preferencialmente, segundo BARNI et al. (1978), COSTA et al. (1979) e SANCHEZ \& YUYAMA (1979) a opção deve ser feita pelo período que proporcione temperatura do solo favorável à germinação, temperatura do ar que favoreça todo o ciclo da planta, fotoperíodo adequado após a emergência e boa distribuição hídrica desde a semeadura até a colheita. 
Para as condições brasileiras, as épocas de semeadura variam em função da região e dos cultivares, geralmente apresentando uma faixa recomendável de outubro a dezembro. Observou-se, porém, que o mês de novembro, de maneira geral, tem proporcionado os melhores resultados de produtividade nos estados em que a cultura é cultivada tradicionalmente (NAKAGAWA et al., 1983). Assim, para o Estado de São Paulo, MASCARENHAS \& MIYASAKA (1968) recomendaram a semeadura da soja na primeira quinzena de novembro.

\subsubsection{Foropexiodo}

De acordo com HARTWIG (1954), o principal fator de adaptação de uma variedade de soja à determinada região é sua resposta fotoperiódica, constituindo-se assim, segundo MOTA (1983) e NOGUEIRA et al. (1984), em importante fator de produção, relacionado à época de semeadura e responsável pela duração do ciclo biológico dos cultivares de soja.

Desta forma, o crescimento vegetativo das plantas de soja ocorre até que o período de luz, diminuindo no verão, se torne menor que o valor crítico para cada cultivar, quando então, se inicia a fase de florescimento. É, portanto, classificada como planta fotoperiódica de dias curtos, embora na realidade seja sensível à extensão do período de ausência de luz, para a indução da formação de botões florais (HARTWIG, 1954). 
Porém, WHIGHAM \& MINOR (1967) e SHANMUGASUNDARAM \& TSOU (1978) relataram que, no início do desenvolvimento, alguns cultivares de soja não respondem com a iniciação de botões florais, mesmo quando submetidos a fotoperíodo menor que o valor crítico para indução do florescimento, passando assim, por um período juvenil.

Considerando que o valor crítico de fotoperíodo para florescimento é específico para cada cultivar, REMUSSI \& PASCALE ${ }^{1}$, citados por MOTA (1983), classificaram os cultivares de soja em precoces, semiprecoces, semitardios e tardios, de acordo com as necessidades bioclimáticas de cada um para iniciar florescimento, de modo que o fotoperíodo crítico para os cultivares precoces é superior ao rlos tardios.

Verifica-se assim que a soja requer condições muito específicas quanto ao fotoperíodo, mormente no período de pré-floração (BERGAMASCHI et al., 1977), de forma que dependendo da época de semeadura, as plantas de cultivares distintos apresentam diferenças quanto ao crescimento e desenvolvimento em decorrência do comprimento do dia, variável de acordo com a latitude e a data. (WHIGHAM \& MINOR, 1967 e VERNETTI, 1983).

1 REMUSSI, C. \& PASCALE, A.J. Classificación bioclimática de variedades de soja. Mimeografado, 1965. 4p. 
É fato bem conhecido que o atraso em relação à época mais apropriada à semeadura da soja reduz a produtividade da cultura (FEASTER, 1949; ABEL, 1961; NICHOLSON \& SINCLAIR, 1973; NAKAGAWA et al., 1983; BOARD \& HALL, 1984 e JOHNSON, 1987).

Neste sentido, diversos autores como FEASTER (1949), HARTWIG (1954), ABEL (1961) e ATHAYDE et al. (1984) salientaram maiores reduções no ciclo de desenvolvimento para os cultivares precoces do que para os médios ou tardios, não só pela maior antecipação no florescimento, mas também algumas vezes pela diminuição do periodo de enchimento de vagens, resultando em quedas mais acentuadas na produção final.

A duração do período vegetativo determina o porte da planta e, conseqüentemente, o desempenho final de cultivares de hábito de crescimento determinado, adaptados ao clima tropical (HANWAY \& THOMPSON, 1971). Vários autores constataram redução na altura das plantas de soja, devido à menor duração do período vegetativo, relacionada a atrasos na semeadura (OSLER \& CARTTER, 1954; TORRIE \& BRIGS, 1955; ABEL, 1961; GRAVES et al., 1978; PAYNE et al., 1978; SANCHEZ \& YUYAMA, 1979; TRAGNAGO \& BONETTI, 1984 e BOARD \& SETTIMI, 1986). ABEL (1961) acrescentou que a redução na altura foi maior para os cultivares de porte alto. 
Ainda com relação a altura das plantas, BOARD \& SETTIMI (1986), nos Estados Unidos, conduziram um experimento, incluindo oito cultivares de grupos de maturação diferentes, porém de hábito de crescimento determinado, onde verificaram que, aproximadamente $2 / 3$ do número total de ramos e do comprimento total destes foram produzidos entre os estádios de desenvolvimento R1 (início do florescimento) e R5 (início do desenvolvimento das sementes). Constataram ainda que, além do período vegetativo, o intervalo entre Rl e R5 também era diminuído proporcionalmente aos atrasos na semeadura, incrementando a redução do número e comprimento totais de ramos produzidos e o número total de nós por ramos, resultando em plantas mais baixas.

Outras características agronômicas e componentes da produção também são afetados pelo florescimento precoce.

Assim, BARNI et al. (1978) e VERNETTI (1983) comentaram que redução no período vegetativo da soja também leva à redução na altura da inserção das primeiras vagens. Segundo QUEIROZ et al. (1981), a altura da inserção da primeira vagem das plantas de soja, visando a colheita mecânica deve ser superior a $13 \mathrm{~cm}$. Todavia, BUENO et al. (1975) observaram que, nas condições de Minas Gerais, apesar do atraso na época de semeadura a partir de 27 de novembro até 4 de janeiro, a altura da inserção das primeiras vagens foi sempre compatível com a colheita mecânica. 
Examinando-se trabalhos relacionados a épocas de semeadura, encontrados na literatura, verifica-se certa unanimidade quanto ao número de vagens por planta, referido como o principal fator que controla o rendimento da cultura da soja (DIMMOCK \& WARREN, 1953; CARTER, 1974; VERNETTI, 1983; TRAGNAGO \& BONETTI, 1984 e BOARD, 1987). De acordo com VERNETTI (1983) e TRAGNAGO \& BONETTI (1984), quanto mais tardia é a semeadura, menor é o número de nós formados na planta, e portanto, menor é o número de vagens por planta.

Quanto ao número de vagens granadas e número de sementes por vagem granada, NAKAGAWA et al. (1983) não encontraram diferenças significativas entre épocas de semeadura.

Ainda consj.derando componentes de produção relacionados ao rendimento de sementes, constata-se que a redução na produção devido ao atraso na época de semeadura está mais associada ao menor número de sementes produzidas do que ao decréscimo no tamanho e, conseqüentemente, ao peso de sementes (DIMMOCK \& WARREN, 1953; NAKAGAWA et al., 1983 e BOARD, 1987). De acordo com OSLER \& CARTTER (1954) e SANCHEZ \& YUYAMÁ (1979), as plantas de soja apresentam condições de produzir sementes de igual peso em todas as épocas de semeadura, a não ser que ocorram condições climáticas desfavoráveis. 
No entanto, NICHOLSON \& SINCLAIR (1973) e NAKAGAWA et al. (1983) obtiveram sementes mais leves em semeaduras mais tardias, fato que para NAKAGAWA et al. (1983), deveu-se ao menor período disponível à produção e translocação de fotossintetizados para a semente, em conseqüència da redução do ciclo cultural e da menor duração dos estádios de desenvolvimento da soja, nessas épocas, resultando em menor peso.

\subsubsection{Termeratura}

A temperatura é outro fator a se considerar na escolha da época de semeadura da soja, visando a obtenção de rendimentos elevados, pois exerce influência sobre todas as fases do ciclo vegetatives da planta.

Enquanto a temperatura média do ar não for superior a $15^{\circ} \mathrm{C}$, o período vegetativo não tem início (BARNI et al., 1978). Temperaturas entre 25 e $30^{\circ} \mathrm{C}$ favorecem tanto a emergência das plântulas como a formação de nódulos e o desenvolvimento das plantas de soja, sendo a última, a temperatura considerada ótima; temperaturas acima de $30^{\circ} \mathrm{C}$ exercem efeitos depressivos sobre a intensidade de desenvolvimento das plantas (BARNI et al., 1978 e MARCOS FILHO, 1986), além de na fase reprodutiva serem letais ao pólen, impedindo a formação de sementes de soja ou tornando-as inviáveis (HARRINGTON, 1972). 
Considerando-se os estudos relacionados à comparação entre datas de semeadura, vale salientar que a temperatura pode modificar as respostas da soja ao fotoperíodo.

Nesse sentido, WHIGHAM \& MINOR (1967) e MOTA (1983) relataram que a floração atrasa quando a temperatura permanece inferior a $25^{\circ} \mathrm{C}$, não ocorrendo, segundo MIRANDA et al. (1982), sob temperaturas menores do que $13^{\circ} \mathrm{C}$. Além disso, MAJOR et al. (1975) constataram que temperaturas baixas associadas a dias longos produziram efeitos aditivos quanto ao retardamento do florescimento da soja; por outro lado, dias curtos encontrados nas épocas de semeadura mais tardias apressaram a ocorrência da maturidade, em intensidade tal que superaram os efeitos retardadores das baixas temperaturas.

Da mesma forma, BERGAMASCHI et al. (1977), avaliando datas de semeadura entre 1 de setembro e 15 de janeiro, observaram que nas regiões mais frias do Rio Grande do Sul, temperaturas cada vez mais baixas aliadas ao encurtamento do fotoperíodo provocaram quedas mais acentuadas no rendimento de sementes de soja, com o decorrer das épocas de semeadura, do que nas regiões mais quentes daquele Estado. NAKAGAWA et al. (1983) também atribuíram ao efeito do fotoperíodo associado à ação de baixas temperaturas, a queda na produção resultante do atraso da semeadura, a partir de meados de outubro ao início de janeiro, em Botucatu, no Estado de São Paulo. 
Quando temperaturas elevadas são associadas a fotoperíodos longos, observa-se aumento na taxa de crescimento e portanto, na altura final das plantas (WHIGHAM \& MINOR, 1967). BERGAMASCHI et al. (1977) acrescentaram que semeaduras mais tardias realizadas em regiões mais quentes permitem que a planta de soja atinja porte razoável, com menor redução no seu potencial de produção, mesmo com a ocorrência de antecipação na época de florescimento, devido aos efeitos associados de temperaturas elevadas e encurtamento do dia. Isto permite, ainda, que a fase reprodutiva ocorra em período de maior disponibilidade térmica, favorecendo a fotossíntese, com benefícios à produção.

Desta maneira, visando o rendimento da cultura, BERGAMASCHI et al. (1977) afirmaram que cultivares de ciclo longo são mais vantajosos para semeaduras tardias em locais quentes, pois nessas condições, os precoces, mesmo contando com boa disponibilidade térmica, têm seu porte e altura da inserção das primeiras vagens consideravelmente reduzidos, aumentando as perdas na colheita mecanizada.

\subsubsection{Disponibilidade hídrica}

Fornecimento de água é outro fator relevante, que afeta o rendimento da soja nas regiões produtoras. Segundo MARCOS FILHO (1986) as regiões aptas à 
cultura da soja são as que apresentam boa distribuição de precipitações pluviais (500-700mm) durante o ciclo das plantas. Doss et al. (1974) observaram que em situações onde a quantidade de água era limitada em alguma fase do ciclo da cultura, a redução na produção dependeu do estádio fenológico, da época e da duração do período de estresse.

Deficiência hídrica durante os estádios vegetativos provocaram redução da taxa de crescimento da planta, resultando em folhas menores, hastes com diâmetro reduzido e plantas mais baixas (WHIGHAM \& MINOR, 1967). Porém, MATSON (1964) e HOOGENBOOM et al. (1987) não constataram reduções acentuadas na produção, com a restrição da irrigação dentro de certos limites, até o início do florescimento, ou com a suspensão da irrigação um mês antes da colheita.

Por outro lado, água insuficiente durante o período de formação e, principalmente, de enchimento das vagens é, freqüentemente, uma das principais barreiras às produções elevadas de soja (WHIGHAM \& MINOR, 1967; DOSS et al., 1974; WESTGATE \& GRANT, 1989 e WESTGATE et al., 1989).

De acordo com SIONIT \& KRAMER (1977) e RASSINI \& LIN (1981), estresse hídrico durante o início do período de formação de vagens (R3) causa maior redução em número de vagens e, conseqüentemente, em número de sementes na colheita; o estresse hídrico durante 0 período de enchimento de vagens (R5) diminui a produção, devido à redução no peso das sementes. RASSINI \& LIN (1981) 
acrescentaram ainda, a queda de vigor das sementes como efeito prejudicial, resultante de períodos de estiagem na fase de enchimento de vagens.

Observa-se que no Estado de São Paulo, semeaduras tardias podem levar à ocorrência das fases de formação e desenvolvimento das sementes de soja em épocas seca. Para garantir a produção de sementes nessas condições, a irrigação torna-se indispensável.

Assim, NAKAGAWA et al. (1983) atribuíram a redução na produção de sementes de soja, a medida em que se atrasava a semeadura de meados de outubro ao início de janeiro, em Botucatu, no Estado de São Paulo, principalmente aos efeitos na redução do fotoperíodo associada a baixas temperaturas e à falta de umidade no solo.

\subsection{Qualidade Fisiólogica da Semente}

A produtividade da cultura da soja pode adquirir caráter secundário quando se raciocina em termos de produção de sementes; neste caso, a obtenção de sementes de boa qualidade passa a ser o objetivo principal.

Dados disponíveis na literatura estrangeira e nacional indicam que em ambientes tropicais ou subtropicais, nem sempre a época de semeadura recomendada para a obtenção de bons rendimentos de sementes de soja coincide com a obtenção de produto com qualidade 
satisfatória. Períodos chuvosos e com temperatura elevada, característicos nessas regiões durante as fases de maturação e colheita, dificultam a obtenção de sementes de soja de qualidade aceitável e a manutenção do vigor durante o armazenamento (CARTTER \& HARTWIG, 1962; CAVINESS, 1978; SILVA et al., 1979; HEPPERLY \& SINCLAIR, 1980; DASSOU \& KUENEMAN, 1984; PAOLINELLI et al., 1984a; KEIGLEY \& MULLEN, 1986 e COSTA et al., 1987a).

No Brasil, principalmente quando a produção de sementes de soja é efetuada em regiões localizadas ao norte do paralelo $24^{\circ} \mathrm{S}$, há sérias preocupações com a qualidade fisiológica (PEREIRA et al., 1979; FALIVENE et al. 1980; MARCOS FILHO et al., 1985; COSTA et al., 1986 e COSTA et al., 1987b) .

Merecem atenção especial os cultivares precoces que, quando semeados em épocas propícias à máxima produtividade, são colhidos em fins de fevereiro e início de março, de forma que a maturação e a colheita coincidem, freqüentemente, com flutuações de temperatura e pluviosidade (PEREIRA et al., 1979; MARCOS FILHO et al., 1985 e COSTA et al., 1987a). Há, inclusive, dúvidas quanto à produção de sementes de cultivares precoces nessas regiões (MARCOS FILHO et al., 1985).

É fato conhecido que a máxima qualidade da semente é atingida por ocasião da maturidade fisiológica simultaneamente ao ponto de máximo potencial de germinação e vigor. Nesse ponto, segundo TeKRONY et al. (1980), a 
semente torna-se independente e a perda de água passa a ser controlada pelas condições do ambiente, sem a participação de atividade fisiológica da planta ou da semente. Infelizmente, a realização da colheita nessa oportunidade é dificultada, devido ao elevado grau de umidade da semente que, de acordo com HOWELL et al. (1959), situa-se entre 50 e $60 \%$; nesta ocasião, a semente exibe intensa respiração, resultando em perdas de matéria seca e óleo. Baixas taxas de respiração passam a ser observadas quando as sementes passam a ter teores de água inferiores a $30 \%$, nas vagens de coloração marrom. A semente permanece na planta até atingir teor de água compatível com a colheita mecânica (FULCO et al., 1979 e TeKRONY et al., 1980).

Segundo MONDRAGON \& POTTS (1974), a deterioração pode ocorrer em qualquer instante até a realização da colheita, resultando da combinação de condições adversas do ambiente, organismos patogênicos (CAVINESS, 1978 e FULCO et al., 1979) e ataque de percevejos (COSTA et al., 1987b). Porém, de acordo com MONDRAGON\& POTTS (1974), os efeitos negativos da deterioração são mais acentuados, durante o processo de dessecação, quando o grau de umidade das sementes é inferior a $25 \%$.

Vale salientar que, devido a características morfológicas e químicas, a semente de soja destaca-se por ser bastante sensível à ação de fatores do ambiente (MARCOS 
FILHO, 1979). Assim, situações ligeiramente desfavoráveis para outras espécies podem contribuir para acelerar significativamente sua deterioração.

Conseqüentemente, umidades relativas do ar e temperaturas elevadas durante o período de maturação aumentam acentuadamente a atividade fisiológica das sementes, predispondo-as ao ataque de patógenos, resultando na redução da germinação e do vigor (CAVINESS, 1978 e COSTA et al., 1987a), podendo causar inclusive germinação das sementes dentro da própria vagem (SANCHEZ \& YUYAMA, 1979). CARRARO et al. (1985) concluíram que a ocorrência de chuvas é mais importante que o tempo de exposição da semente às condições de campo, após sua maturação. Porém, se o ambiente apresentar umidade relativa do ar igual ou inferior a 70\%, a conservação da semente de soja é favorecida (MARCOS FILHO \& VINHP,, 1980).

Por outro lado, SANCl:LEZ \& YUYAMA (1979) observaram que temperaturas elevadas associadas à umidade relativa do ar baixa podem interromper a maturação das sementes, causando a presença de sementes verdes $e$ enrugadas. Após a maturidade sob tais condições, a semente seca rapidamente, ocasionando perdas por danos mecânicos. TACHIBANA et al. (1968) e FALIVENE et al. (1980) constataram também que a exposição da planta de soja a períodos crescentes de temperatura elevada $\left(32^{\circ} \mathrm{C}\right.$ durante - dia e $28^{\circ} \mathrm{C}$ durante a noite) na fase de enchimento de sementes leva à deterioração dos cotilédones, resultando no aparecimento de necroses e declínio linear na germinação e no vigor destas sementes. 
A qualidade pode ser mais prejudicada ainda, sob condições de campo, quando sementes maduras são expostas à alternância de secagem e umedecimento, sendo que os principais processos deteriorativos iniciam-se quando a semente relativamente seca é exposta à água da chuva ou ao orvalho. Durante a exposição inicial o tegumento da semente resiste naturalmente à rápida absorção de água. Com exposições repetidas, a resistência é reduzida gradativamente, resultando em tegumentos afrouxados, enrugados, secos e com fissuras. Sementes grandes tendem a adquirir mais distúrbios do que as pequenas (MOORE, 1971).

Diante destas situações, ANDREWS (1982) sugeriu que as regiões geograficamente favoráveis à produção de sementes com germinação, vigor e sanidade elevados seriam as de baixa precipitação, sem orvaiho ou nevoeiro e com baixa umidade relativa do ar, nos períodos que incluem a maturação até a colheita.

Entretanto, alternativas têm sido propostas, com o objetivo de melhorar a qualidade das sementes produzidas nas regiões tropicais, como por exemplo a escolha de locais situados em altitudes mais elevadas, onde - ar é mais rarefeito e o vapor d'água menos abundante, afetando a radiação solar, temperatura e umidade relativa do ar. Resultados positivos nesse sentido, foram encontrados em Minas Gerais (PAOLINELLI et al., 1984a) e em Goiás (COSTA et al., 1984 e 1988). 
Outra alternativa refere-se ao cultivo da soja na entressafra, caracterizada por período seco, empregando-se irrigação suplementar, visando a ocorrência da maturação da soja em período seco e de temperaturas mais baixas (COSTA et al., 1984).

Esta proposta tem sido avaliada em diversos países, onde se cultiva soja, com atenção especial à produção de sementes dos cultivares precoces. Na literatura encontram-se dados a esse respeito, desde o final da década de 40 até os nossos dias.

Nos Estados Unidos, diversos autores obtiveram sementes de cultivares precoces de soja com melhor qualidade, produzidas em semeaduras mais tardias do que a recomendada para a obtenção de maiores produtividades (FEASTER, 1949; TORRIE \& BRIGGS, 1955 e ABEL, 1961). Sementes de cultivares tardios eram pouco afetadas por esse proceciimento.

Observações como obtenção de sementes com melhor germinação e emergência de plântulas em campo em épocas de semeadura mais tardias, com efeitos mais pronunciados para cultivares de ciclo precoce e médio em relação aos tardios, foram relatadas por GREEN et al. (1965). Da mesma forma, TeKRONY et al. (1984) registraram melhores resultados de germinação, primeira contagem de germinação e envelhecimento artificial e menor infecção por Phomopsis spp, à medida em que o ponto de colheita de sementes de cultivares precoces ocorria em época mais seca, devido a atrasos na semeadura. 
NICHOLSON \& SINCLAIR (1973), na Índia, também constataram niveis decrescentes de sementes com incidência de microrganismos, manchas púrpura ou marrom e níveis crescentes de germinação, da primeira à sétima época de semeadura, efetuadas com intervalo de 10 dias. Nas primeiras épocas de semeadura ocorreram longos periodos de chuva na maturação das sementes.

No Brasil, estudos semelhantes foram conduzidos nos principais estados produtores de soja, a partir do final da década de 70. Nesse sentido, PEREIRA et al. (1979), no Paraná, PAOLINELLI et al. (1984b), em Minas Gerais, TRAGNAGO \& BONETTI (1984), no Rio Grande do Sul e NAKAGAWA et al. (1984a,b e 1986), em São Paulo, conduziram experimentos visando avaliar a qualidade de sementes produzidas em diversas épocas de semeadura. Para tanto, empregaram diversos cultivares de ciclos de maturação diferentes, semeados nos meses de outubro a dezembro. De modo geral, os autores chegaram a conclusões semelhantes: verificaram que principalmente os cultivares precoces apresentavam sementes de melhor qualidade, à medida em que se atrasava a semeadura, de modo que semeaduras a partir do início do mês de dezembro permitiram que a maturação e a colheita de sementes ocorressem em condições de temperaturas mais baixas, acompanhadas por menores volumes de chuva. 


\subsection{Sanidade da Semente}

\subsubsection{Fungos}

Outro fator a ser considerado na escolha de uma época de semeadura que proporcione produção de sementes de elevada qualidade, refere-se à veiculação de patógenos pela semente.

Mais de cem espécies conhecidas de microrganismos infectam a soja, sendo que desses apenas 35 são economicamente importantes (SINCLAIR, 1991). A maioria dos patógenos da soja é de natureza fúngica; dentre estes, um número considerável pode ser transmitido facilmente através da semente. Assim, esta pode ser considerada como eficiente veículo de disseminação de patógenos dentro da mesma cultura ou para áreas ainda livres (SINCLAIR, 1982). Além desse aspecto, de acordo com TANAKA et al. (1984), a associação de certos microrganismos com a semente de soja pode resultar em efeitos diretos, como a redução do potencial de germinação, do vigor, da emergência, do período de armazenamento e até do rendimento.

Em regiões onde ocorrem chuvas e altas temperaturas, durante os períodos de maturação e colheita, além da dificuldade de obtenção de sementes com germinação e vigor aceitáveis (TANAKA et al., 1984 e JORDAN et al., 1988), os patógenos passam a desempenhar relevante papel, por encontrarem condições ideais para intensa atividade; 
tanto é que VAUGHAN et al. (1989) associaram a pior qualidade de sementes de cultivares precoces em relação aos tardios à presença de patógenos nas sementes, favorecida pelas condições de temperatura e umidade relativa do ar elevadas, encontradas pelos cultivares precoces que amadurecem mais cedo que os tardios, quando semeados em época normal.

SINCLAIR (1991) ressaltou que dentre os fungos que causam infecções latentes, encontram-se os principais patógenos transportados pelas sementes de soja: Phomopsis spp, Cercospora kikuchii, Colletotrichum spp, Macrophomina phaseolina e Fusarium spp.

Assim, esses fungos podem infectar as vagens em diversos estádios de desenvolvimento da planta; porém, a porcentagem de sementes infectadas, geralmente aumenta acentuadamente, se as condições do ambiente forem propícias quando as plantas aproximam-se da maturidade, crescendo ainda mais se a colheita for retardada (KILPATRICK, 1957; ATHOW \& LAVIOLETTE, 1973; HILL \& WEST, 1982 e BALDUCCHI \& MCGEE, 1987).

Além destes, outros fungos patogênicos isolados com maior ou menor freqüência de sementes de soja foram relacionados na literatura: Sclerotinia sclerotiorum, Myrothecium (NICHOLSON \& SINCLAIR, 1973), Rizoctonia solani (NICHOLSON\& SINCLAIR, 1973 e DHINGRA et al., 1979a) Peronospora manshurica (BUENO et al., 1975), Trichotecium roseum (TANAKA et al., 1984) e Cercospora sojina (SINGH \& SINCLAIR, 1985). 
Os patógenos podem invadir a semente de soja antes do início do período de dessecação, através da micrópila, abertura natural presente desde o início do desenvolvimento da semente, e/ou através de poros que se formam no tegumento da semente entre os estádios R7 (maturidade fisiológica) e R8 (colheita), associados ao período de dessecação; principalmente este período caracteriza-se por grande invasão das sementes por patógenos (HILL \& WEST, 1982; VAUGHAN et al., 1987 e KULICK e YAKLICH, 1991). Danificações no tegumento da semente de soja também constituem pontos potenciais de entrada e colonização por fungos (BAKER, 1972); além disso, sementes pequenas são menos infectadas, por apresentarem menores índices de danos no tegumento (NANGJU, 1979).

Considerando-se o relevante papel do clima no processo de infecção da semente, verifica-se que a semeadura de un determinado cultivar, em diferentes datas, promove o desenvolvimento da cultura sob diferentes condições do ambiente, de forma que as sementes produzidas poderão apresentar variações quanto à incidência de patógenos, de acordo com a época de semeadura.

Esta preocupação levou vários autores a constatarem que o patógeno isolado com maior freqüência das sementes de soja, Phomopsis spp (ELLIS et al., 1974; BOLKĀN et al., 1976; HEPPERLY \& SINCLAIR, 1981; FRANÇA NETO \& WEST, 1989a e OSORIO \& MCGEE, 1992), apresenta níveis de ocorrência reduzidos, principalmente em sementes de 
cultivares precoces, a medida em que se atrasa a época de semeadura em relação às épocas normalmente recomendadas para a obtenção de máximas produtividades (KILPATRICK \& HARTWIG, 1955; DHINGRA et al., 1979a e b; TeKRONY et al., 1983 e 1984 e PAOLINELLI et al., 1984b).

Durante e após a maturação da vagem e da semente, $O$ ambiente desempenha o principal papel no estabelecimento dos níveis de infecção da semente de soja por Phomopsis spp. Diversos autores constataram que a incidência desse patógeno foi incrementada pela ocorrência de chuvas (DHINGRA et al., 1978; SHORTT et al., 1981; SPILKER et al., 1981; WILCOX et al., 1985; RUPE \& FERRISS, 1986 e BALDUCCHI \& MCGEE, 1987), ou devido a irrigações por aspersão (ROSS, 1975 e KULIK \& YAKLICH, 1991) no período de maturação das sementes. Os maiores níveis de infecção das sementes por Phomopsis spp não se verificaram, necessariamente, quando as temperaturas eram mais elevadas nesse período (SHORTT et al., 1981 e JARDINE, 1991). Na realidade, a temperatura só influenciou a taxa de infecção das sementes em períodos úmidos (SPILKER et al., 1981; SHORTT et al., 1981 e BALDUCCHI \& MCGEE, 1987).

\section{De acordo com WALLEN \& CUDDY (1960),} PETTERSON \& STRELECKI (1965), ELLIS et al. (1974) e BOLKAN et al. (1976), Phomopsis spp pode prejudicar a aparência, a sanidade, a germinação e segundo GOULART et al. (1990), - vigor das sementes de soja, tendo sido isolado com a mesma freqüência tanto a partir do tegumento quanto do embrião da semente de soja (BOLKAN et al., 1976). 
Autores como THOMISON et al. (1988), VAUGHAN et al. (1989) ABNEY \& PLOPER (1991) e PLOPER et al. (1992) constataram que, quanto menor for $o$ intervalo entre a maturidadade fisiológica (estádio R7) e a colheita (estádio R8), menores serão as chances de infecção e colonização destas por Phomopsis spp. Entretanto, há referências de que este fungo pode colonizar a semente, mesmo antes da ocorrência da maturidade fisiológica (TeKRONY et al., 1980 e VAUGHAN et al., 1989).

Cercospora kikuchii é outro fungo encontrado em todas as regiões onde a soja é cultivada, infectando folhas, hastes, vagens e causando mancha de coloração púrpura na semente de soja (PATHAN et al., 1989). Pode levar a perdas econômicas, se as sementes com sintoma de mancha púrpura ocorrerem em nível tal que o lote não atenda aos padrões de sementes vigentes (SCHUH, 1992).

De acordo com os dados encontrados na literatura, os efeitos de épocas de semeadura sobre a incidência de infecção de sementes de soja por C. Kikuchii não são tão evidentes quanto os verificados para Phomopsis spp, de forma que KILPATRICK \& HARTWIG (1955), avaliando oito épocas quinzenais de semeadura na Flórida, EUA, isolaram com maior frequência $C$. kikuchii das sementes produzidas nas primeiras semeaduras em 1952 e na última semeadura em 1953. Porém, NICHOLSON \& SINCLAIR (1973) constataram niveis decrescentes de sementes com mancha púrpura da primeira até a última época de semeadura, 
realizadas entre junho e setembro, na Índia. JORDAN et al. (1988) também verificaram que dentre 16 cultivares, os que amadureceram mais cedo, mais expostos a temperaturas e pluviosidades mais elevadas foram mais suscetíveis a $C$. kikuchii.

Os estudos direcionados à avaliação de épocas de semeadura, que envolveram a sanidade de sementes produzidas nas diferentes épocas, limitaram-se de modo geral, a discussões que incluíam principalmente Phomopsis spp e C. kikuchii, em menor proporção. Existem na literatura poucas referências a esse respeito, considerando os demais patógenos, que podem infectar sementes de soja. Porém, BUENO et al. (1975) verificaram que apesar de o retardamento da época de semeadura a partir de 27 de novembro até 4 de janeiro ter melhorado a qualidade das sementes de soja de dois cultivares tardios, no ano agrícola de 1973/74, em 1974/75 a incidência de Míldio (Peronospora manshurica), mais intensa na última época de semeadura, prejudicou a qualidade das sementes.

De acordo com SINCLAIR (1982), a infecção de sementes de soja por Peronospora manshurica pode ser caracterizada por ausência de brilho e cobertura parcial ou total do tegumento por incrustações esbranquiçadas, de aparência pulverulenta, constituídas pelos esporos de resistência (oósporos) do fungo. A maioria dessas sementes, segundo FERREIRA et al. (1981), dá origem a plantas sadias; poucas não chegam a produzir plântulas e apenas um pequeno 
número delas produz plantas sistemicamente infectadas. Porém, esses autores não recomendam o uso destas sementes para semeadura.

Outros fungos isolados com bastante freqüência das sementes de soja de cultivares de diversos grupos de maturação estudados por DHINGRA et al. (1979b), em Minas Gerais, foram Fusarium semitectum e Colletotrichum dematium; esta ocorrência, no entanto, foi observada com níveis semelhantes nas duas épocas de semeadura avaliadas, sendo a primeira no mês de novembro e a segunda em dezembro.

Entretanto, várias espécies de Fusarium são comumente observadas em sementes de soja com baixo poder germinativo. Esses fungos, considerados por muitos como saprófitas, são potencialmente perigosos em condições tropicais, com prolongados períodos de alta umidade nas fases finais do ciclo da cultura. Nessas condições, infectam facilmente a semente. Tudo indica que a semente adquire 0 fungo pelo contato com a vagem infectada (DHINGRA, 1978). Picadas de percevejos também podem levar a acréscimos na incidência de Fusarium spp em sementes de soja (RUSSIN et al., 1988).

Colletotrichum dematium é outro patógeno transmitido pela semente de soja, podendo reduzir a produção e a qualidade das sementes. Coloniza o tegumento das sementes, embora nem sempre os sintomas sejam visíveis. Pode atingir os cotilédones e causar necrose na base do 
hipocótilo, sem invadir, no entanto, elementos vasculares (MARCANO \& SINCLAIR, 1978). FRANÇA NETO \& WEST (1989b) observaram, nos Estados Unidos, que $30 \%$ das amostras coletadas de 23 cultivares de soja, apresentavam 5 a 20\% de sementes infectadas por Colletotrichum truncatum. Embora a infecção tenha se restringido principalmente ao tegumento das sementes, metade dos lotes com elevados níveis de infecção apresentava 1 a $10 \%$ de sementes com embrião infectado pelo fungo.

Outros patógenos de ocorrência menos freqüente, embora prejudiciais à sanidade das sementes de soja, também têm sido relacionados. Por exemplo, elevados níveis de Alternaria spp têm sido associados a condições úmidas do ambiente, injúrias causadas pelo frio e picadas de percevejos. Esse fungo infecta, principalmente, o tegumento das sementes, em menor nível os cotilédones, não atingindo o eixo embrionário (KUNWAR et al., 1986). Além disso, ROSS (1975) observou relação inversa entre Phomopsis spp e Alternaria spp, sugerindo antagonismo entre esses organismos. Macrophomina phaseolina apresenta ampla distribuição na maioria das culturas de soja e sua ocorrência torna-se severa, principalmente, sob prolongados períodos de estiagem. A semente infectada geralmente não chega a emergir, ou origina plântula fraca que acaba morrendo (SINCLAIR, 1982). 
Outro fungo, Cercospora sojina pode ser encontrado em todas as regiões do mundo onde se cultiva soja; é transmitido pela semente, reduzindo sua qualidade por causar manchas no tegumento de coloração cinza a marron; seu estabelecimento na semente é restrito aos tecidos do tegumento e ao espaço entre o tegumento e o embrião; porém, pode crescer para o interior dos tecidos da plântula durante a germinação e a emergência (SINGH \& SINCLAIR, 1985) .

Embora os fungos que infectam as sementes de soja no campo caracterizem-se por perder a sua viabilidade nas sementes no período compreendido entre a colheita e a comercialização e semeadura das mesmas, o armazenamento não garante a qualidade sanitária das sementes. Estas podem ser infectadas por fungos de armazenamento, que de acorclo com CHRISTENSEN (1973), caracterizam-se pela habilidade de crescer sem água livre, compreendendo diversas espécies de Aspergillus, acrescidas de algumas espécies de Penicillium. Ocorrem de forma generalizada em todas as partes do mundo, contaminando grãos e sementes, invadindo preferencialmente - embrião e, conseqüentemente, reduzindo o potencial de germinação da semente.

De acordo com CHRISTENSEN (1973) e LAZZARI \& MERONUCK (1988), tais fungos podem ainda causar acréscimo no teor de água, acompanhado por redução da matéria seca de sementes de soja armazenadas com diferentes graus iniciais de umidade e mantidas sob diversas temperaturas. 
Todos esses fungos crescem em sementes com teores de água em equilíbrio com umidades relativas do ar entre 70 e $90 \%$. Penicillium spp crescem, principalmente em sementes com teores de água em equilíbrio com umidades relativas do ar acima de 85\%. Cada espécie de Aspergillus cresce em sementes com teores de água em equilíbrio com umidades relativas do ar específicas, entre 65 e 85\% (CHRISTENSEN, 1973) .

Ainda segundo CHRISTENSEN (1973), a temperatura ótima para crescimento da maioria dos fungos de armazenamento situa-se entre $30^{\circ}$ e $33^{\circ} \mathrm{C}$ e a mínima entre 0 e $5^{\circ} \mathrm{C}$.

\subsubsection{Insetos}

A qualidade de sementes de soja pode ser prejudicada ainda no campo por um complexo de percevejos fitófagos (Hemiptera:Pentatomidae) que inclui Nezara viridula, Acrosternum hilare, e várias espécies do gênero Euchistus. Os danos ocorrem quando adultos e ninfas picam sementes e alimentam-se do conteúdo liquidificado por enzimas salivares. As evidências visíveis da alimentação dos percevejos podem variar de simples pontuações a enrugamentos extensivos das sementes. Esses danos têm sido associados a decréscimos na germinação das sementes e emergência das plântulas (RUSSIN et al., 1988) . 
PANIZZI et al. (1978), no Estado do Paraná, avaliaram o efeito de três épocas de semeadura, de outubro a dezembro, sobre a população de percevejos associados à soja. As principais espécies encontradas foram Nezara viridula (L.), Piezodorus guildinii (West) e Euchistus heros (Fabr). Nas três épocas, os percevejos começaram a aparecer na fase de floração (R1-R2); a população aumentou acentuadamente no enchimento de grãos (R5-R6), atingindo o pico na maturidade fisiológica da soja (R7). A maior densidade populacional de percevejos verificou-se no final de fevereiro e março. Na primeira e segunda época, a ocorrência de sementes danificadas foi maior, relacionandose às maiores populações de percevejos encontradas nesses períodos. Comentaram ainda que as semeaduras precoces tendem a proporcionar semertes mais danificadas por percevejos que as tardias, devido provavelmente à maior duração do período floração-maturação.

$$
\text { Por outro lado, PEREIRA et al. }
$$

verificaram que em semeaduras mais tardias, a partir de 20 de dezembro, cultivares semi-tardios sofreram ataques mais severos de percevejos. Segundo os autores, o fato de $80 \%$ da área cultivada com soja no Paraná já ter sido colhida na ocasião determinou a transferência da população de percevejos para as lavouras remanescentes. 
Pelo exposto, pode se verificar que a obtenção de dados, referentes ao comportamento agronômico de cultivares de soja semeados em diferentes épocas é de fundamental importância para a indicação do melhor período de semeadura para cada cultivar, visando a produção de sementes de melhor qualidade.

Pesquisas nesse sentido devem ser regionalizadas o máximo possível, na tentativa de submeter a cultura às condições do ambiente dominante em cada região, uma vez que a escolha da época de semeadura mais adequada à produção de sementes de qualidade satisfatória deve ser baseada nos efeitos de fatores do ambiente, como fotoperíodo, temperatura, umidade relativa do ar e água disponível no solo, considerados em conjunto em cada fase do ciclo da cultura da soja.

Além disso, examinando-se a literatura, fica evidente a falta de informações relativas a semeaduras conduzidas a partir do mês de janeiro. Considera-se que a instalação de campos de produção de sementes de cultivares precoces de soja a partir do mês de março, com o emprego de irrigação suplementar, pode reduzir o risco de ocorrência de condições climáticas desfavoráveis à maturação das sementes, além de diminuir o período de armazenamento desse material até a sua utilização na próxima safra. Ainda, pode aumentar a eficiência de uso da terra, permitindo a instalação de campos de produção de sementes de soja, após a colheita de outras culturas semeadas nos meses de outubro/novembro. 


\section{MATERIAL E MÉTODOS}

A presente pesquisa foi conduzida no período de novembro de 1989 a dezembro de 1990. Os ensaios de campo foram instalados no Centro Experimental de Campinas e na Estação Experimental de Votuporanga do Instituto Agronômico do Estado de São Paulo (IAC). A avaliação da qualidade fisiológica das sementes foi realizada nos Laboratórios de Análise de Sementes do Sistema de Produção de Sementes do IAC e da Coordenadoria de Assistência Técnica Integral (CATI), em Campinas-SP e do Departamento de Agricultura da Escola Superior de Agricultura "Luiz de Queiroz", da Universidade de São Paulo, em Piracicaba-SP.

\subsection{Sementes e Cultivares}

Para a execução do trabalho foram empregadas sementes básicas, produzidas no ano agrícola de 1988/89, de cinco cultivares de soja (Glycine max (L.) Merrill) recomendados para o Estado de São Paulo: 'IAC-100', 'IAC16', e 'IAC-Foscarin-31', provenientes do IAC e produzidas respectivamente, nas regiões de Assis, Campinas e Mococa, no Estado de São Paulo; 'BR-4', procedente do Centro 
Nacional de Pesquisa da Soja (CNPSo) da Empresa Brasileira de Pesquisa Agropecuária (EMBRAPA) e produzidas na região de Dourados-MS e 'IAS-5', procedente da CATI e produzida em Manduri-SP.

Os cinco cultivares utilizados são de ciclo de maturação precoce quando semeados em novembro, época recomendada para a obtenção de maiores produções no Estado de São Paulo, sendo que algumas características agronômicas dos cultivares são apresentadas na Tabela 1 .

\subsection{Ensaios de Campo}

O trabalho foi conduzido em condições de campo, em duas épocas experimentais: a primeira $\left(S_{1}\right)$, com semeadura em 29/11/89 em Campinas e 20/11/89 em Votuporanga e a segunda $\left(\mathrm{S}_{2}\right)$, com semeadura em 27/03/90 em Campinas e 03/04/90 em Votuporanga. Em cada época, os ensaios foram instalados simultaneamente no município de Campinas, definido pelas coordenadas geográficas: altitude 669m, latitude $22^{\circ} 54^{\prime} \mathrm{S}$ e longitude $47^{\circ} 5^{\prime} \mathrm{W}$.Grw. e no município de Votuporanga, definido pelas coordenadas geográficas: altitude 505m, latitude $20^{\circ} 25^{\prime} \mathrm{S}$ e longitude $49^{\circ} 59^{\prime}$ W.Grw. Os dados de precipitação pluvial diária e de temperaturas máximas e mínimas diárias, referentes aos períodos dos experimentos, coletados nos Postos Meteorológicos do Centro Experimental de Campinas e da Estação Experimental de Votuporanga encontram-se nas Figuras 1, 2, 3 e 4 respectivamente. 
Tabela 1. Características dos cultivares precoces empregados na presente pesquisa, quando a semeadura é efetuada no mês de novembro.

Cultivares

Caracteristicas

IAC-100 IAC-16 IAC-Foscarin-31 BR-4 IAS-5

\begin{tabular}{lccccc} 
Porte (cm) & 60 a 70 & 89 & 92 & 52 a 84 & 38 a 66 \\
\hline Ciclo (dias) & 120 & 115 a 125 & 115 & 110 a 120 & 110 a 120 \\
\hline & & & & & \\
\hline Hábito de Crescimento & determinado indeterminado & indeterminado & determinado determinado
\end{tabular}

Florescimento

$\begin{array}{llllll}\text { (dias após a semeadura) } & 65 & 35 \text { a } 40 & 30 \text { a } 35 & 45 \text { a } 50 & 30 \text { a } 35\end{array}$

Altura da inserção

$\begin{array}{llllll}\text { da primeira vagem }(\mathrm{cm}) & 10 & 15 & 16 \text { * } & 17 & 13\end{array}$

Peso médio de

$\begin{array}{llllll}1.000 \text { sementes }(g) & 100 \text { a } 110 \quad 180 & 154 * & 180 & 134 \text { a } 210\end{array}$

$\begin{array}{lllllll}\text { Produtividade média } & 2.000 & 2.300 & 2.840 & 2.500 & 2.500\end{array}$

(kgfha)

Fontes: SÃO PAULO (1990)

* MARCOS FILHO \& NOVEMBRE (1990). 


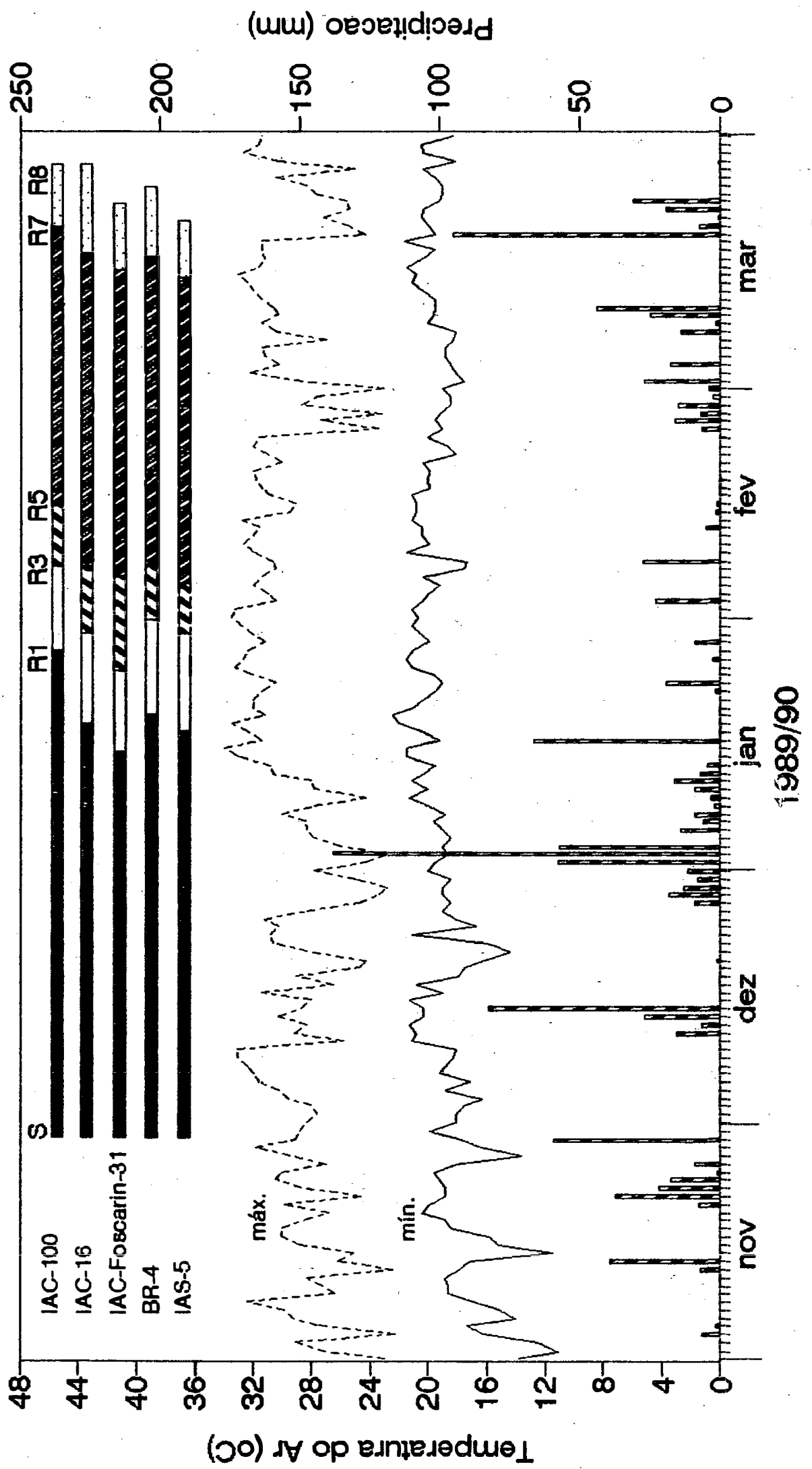

00
0
$0 .-7$
0.4
0.0
$0 .-1$
0.0

ठ

の

出

40

ro

م..

の $0 \begin{gathered}0 \\ 0 \\ 0\end{gathered}$

क

임

$-100$

O

동 罗

क ज $x$

(1) 0 .

$\infty$ ठृ

D

- 10

ठ大

प11

$0 \infty \frac{4}{0}$

(1) 品

(1) हू

$\rightarrow$

तै

पy

吉电

ปे

o 1 .

殅告

- 0

0

. ك

का ซ

1 宁

(1)

○

${ }_{-\rightarrow}$ क क

يم

范四

-

: 
(wu) oeoelpl !odd

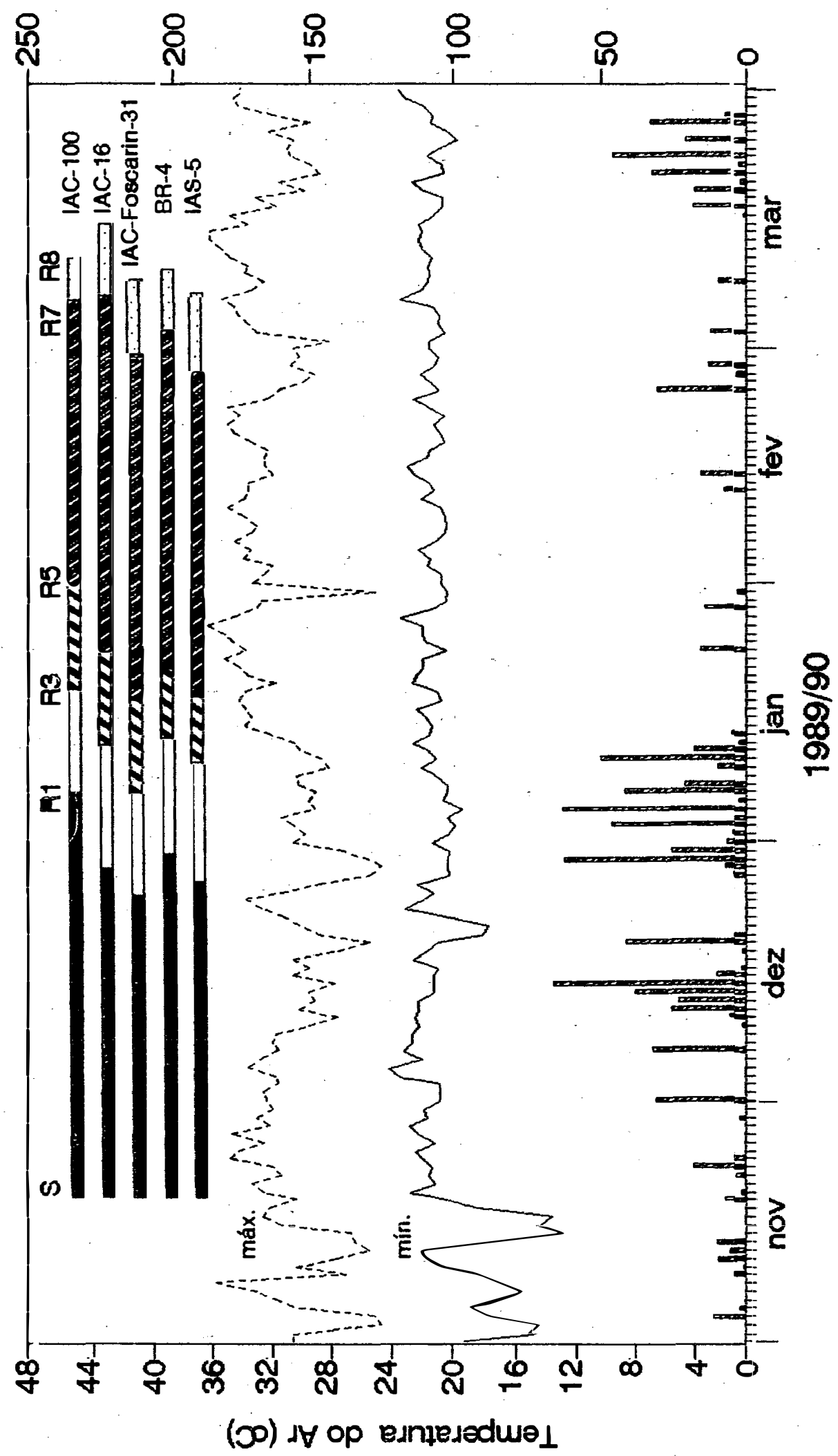

$\stackrel{\oplus}{0}$

\%

$+$

\%

ले

क $P$.

品瓷

の ठठ

O) 다

- 0 욤

ठ․

雨

음

(1) न्न

4.

क ज

잉

नु ॥ प

ro

事品

(1)

(1)

$0-0$

क्ष

ना 0

प्रा

구

ᄀ $\mathrm{H}$ 品

गै

엉요

$0 \ldots$

บ

.. 4ै

ज光

\% 0

1 \&्य

$\infty 0$

क

द्व

นู 으

Q

万人

후

O O O

i

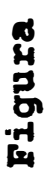


(ww) oeoeyl!loodd

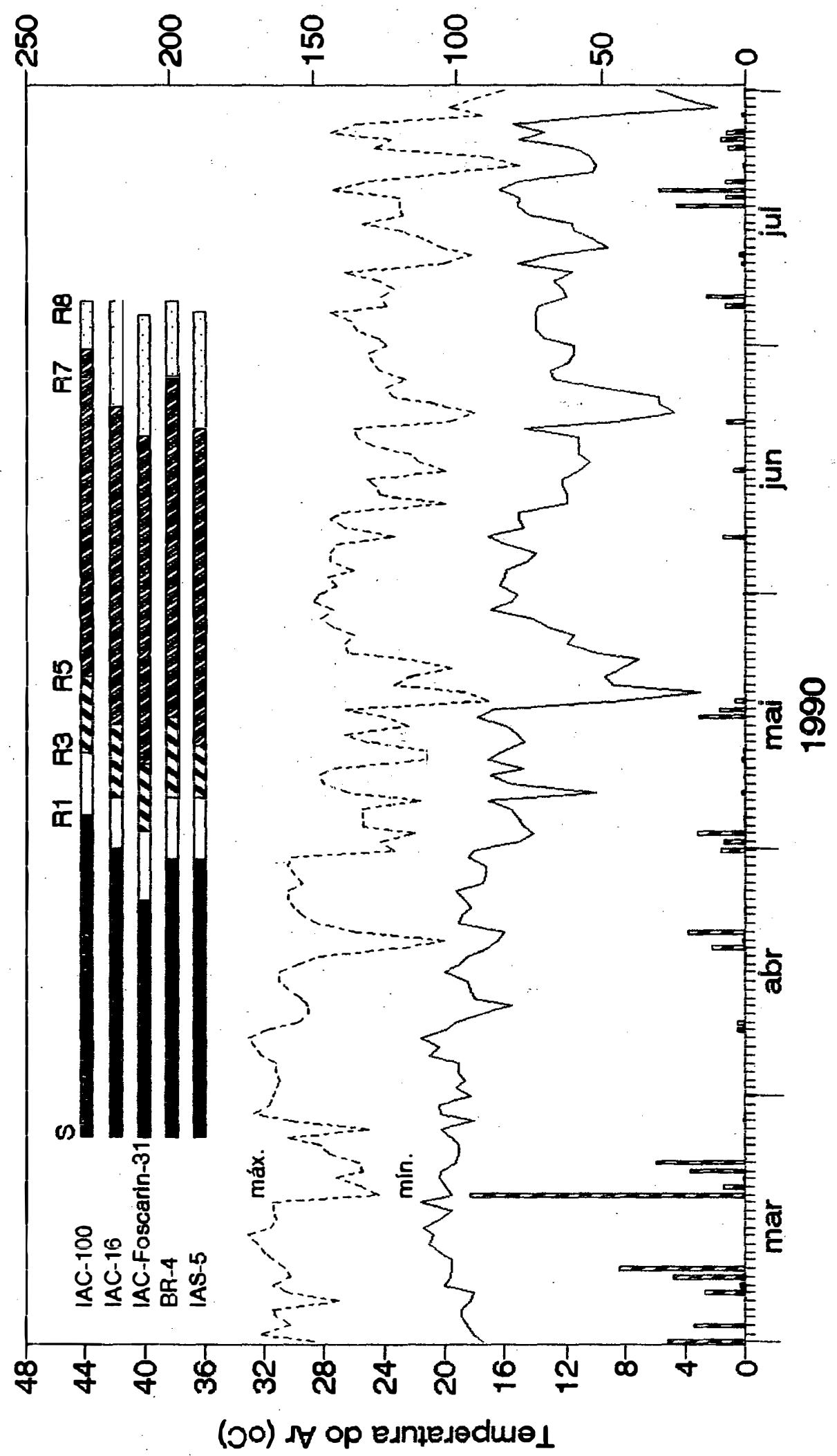

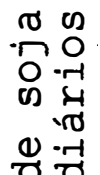

क क

잉

莒

.

क ज

ช

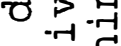

क

으묘

नु앙

요

त्र \& है

(1)

4. ह

थ ग

$-\rightarrow+0$

नु क

r 0

का 11 ช

$0 \infty$

(1) 只

(1)

-1

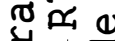

ป

卉约

บ $m$ -

क म्न

ن감

-r

U . . O

$\because \pi 0$

ขึ ช్ ช్

1 ర్ర

の

ช

С ळ

ใ.

苋四

m 
(um) oeoeyd!oәdd

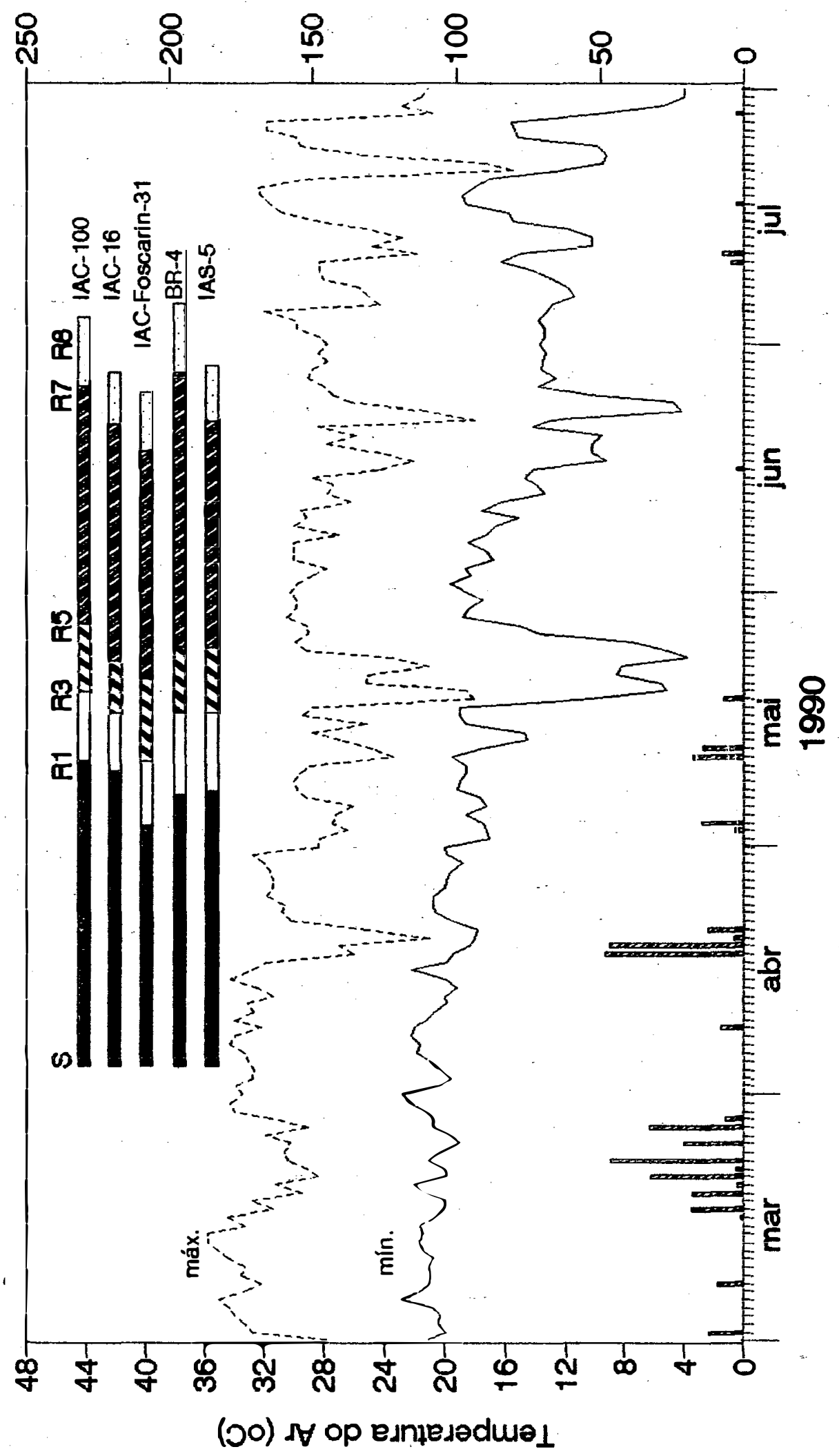

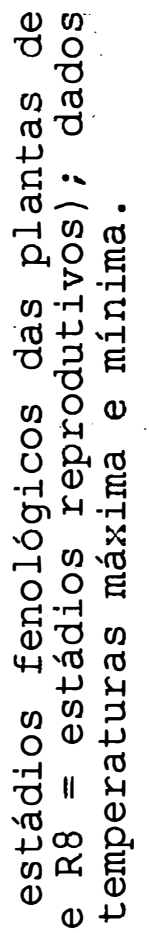

1) ชิ

ते -0

배요

卉 -5

Uव

क

겅 망

0 ...

ช

. Эู

थ

(1)

1 造

o

宅॥

ț O O

O $=0$

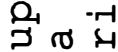

7.

今 0 \%

$\underset{0}{0}$ 
Os solos dos locais dos experimentos foram classificados como Latossolo Vermelho-Escuro (LE) textura argilosa, em Campinas e Podzolizado Vermelho-Amarelo (PVA) textura média, em Votuporanga.

Baseando-se nos resultados das análises químicas de amostras de solo retiradas desses locais (Tabela 2) e nas recomendações encontradas em Boletim do Instituto Agronômico (VAN RAIJ et al., 1985), foram calculadas as doses e realizadas as calagens e adubações com fósforo e potássio. As calagens consistiram na incorporação de duas toneladas/hectare de calcário calcinado por ocasião do preparo do solo para semeadura, nos dois locais e épocas estudados; as adubações foram realizadas no momento da semeadura, através da aplicação de fósforo nas dosagens de $40 \mathrm{~kg} \quad \mathrm{P}_{2} \mathrm{O}_{5} / \mathrm{ha}$ em Campinas e $80 \mathrm{~kg}$ $\mathrm{P}_{2} \mathrm{O}_{5} /$ ha em Votuporanga, fornecido pelo superfosfato simpies; aos 20 dias após a semeadura, foi efetuada a adição de potássio em cobertura na dosagem de $20 \mathrm{~kg} \mathrm{~K}_{2} \mathrm{O} / \mathrm{ha}$, fornecido pelo cloreto de potássio, em todos os ensaios.

o delineamento experimental empregado foi o de blocos casualizados (cinco cultivares e cinco repetições). Cada ensaio constou de parcelas constituídas por cinco linhas de 6m, espaçadas de 0,50m entre si, com

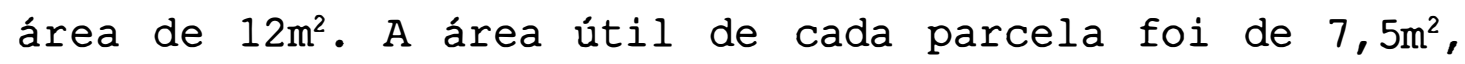
consistindo na utilização das três linhas centrais, desprezando-se como bordadura, $0,50 \mathrm{~m}$ das extremidades e as duas linhas laterais. 
Tabela 2. Análises químicas do solo - valores médios obtidos através das amostras retiradas dos locais onde se instalaram os ensaios de campo, em cada local e época de semeadura.

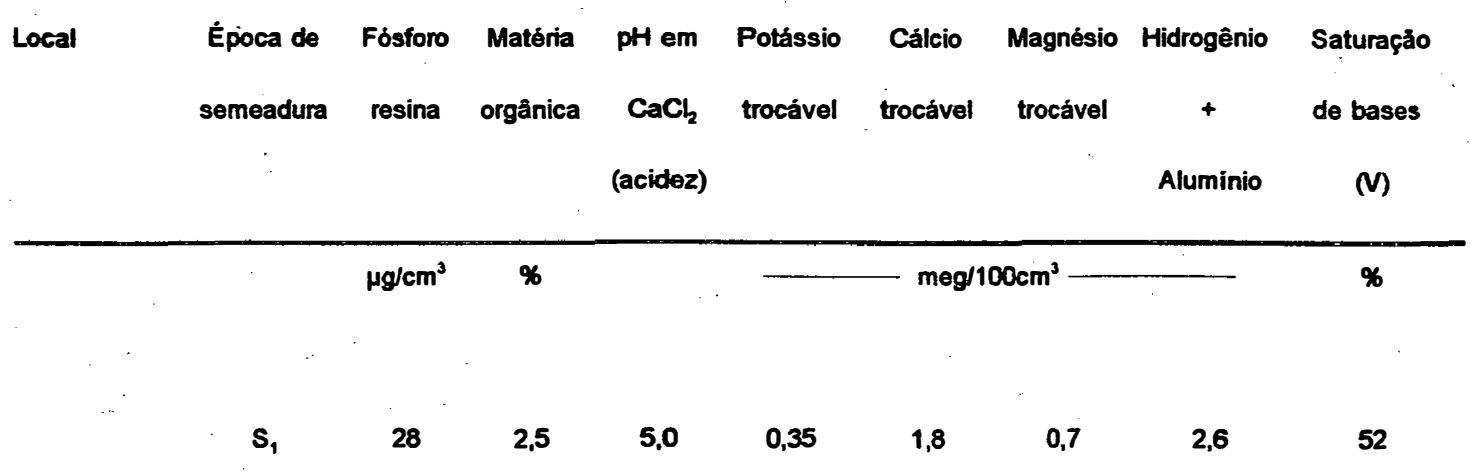

Campinas

\begin{tabular}{|c|c|c|c|c|c|c|c|}
\hline$S_{2}$ & 27 & 2,3 & 5,4 & 0,18 & 2,8 & 1,0 & 2,5 \\
\hline $\mathbf{S}_{1}$ & 4 & 1,5 & 4,7 & 0,26 & 0,9 & 0,5 & 1,8 \\
\hline
\end{tabular}

Votuporanga

\begin{tabular}{lllllllllll}
$5_{2}$ & 4 & 1,6 & 4,8 & 0,25 & 1,1 & 0,5 & 1,8 & 50 \\
\hline
\end{tabular}

A quantidade de sementes empregadas na semeadura foi calculada com base nas informações obtidas através do teste de germinação, porém realizada de forma à proporcionar um maior número de plantas por metro linear em relação ao indicado, garantindo-se desta forma o estande desejado (vinte plantas por metro), através de desbaste efetuado após a emergência; a inoculação com Rhizobium foi feita nos sulcos, no momento da semeadura. 
Durante a condução da cultura, o fornecimento de água foi suplementado por aspersão, de forma que nunca se passassem mais do que cinco dias sem irrigação (chuva ou aspersão).

Segundo BERLATO \& BERGAMASCHI (1978), quando não há restrição de água no solo, a evapotranspiração média da cultura da soja é de 5,8m/dia. Assim, a quantidade de água fornecida foi calculada, multiplicando-se este valor pelo número de dias sem irrigação (cinco), resultando em aproximadamente $30 \mathrm{~mm}$ de água por irrigação suplementada.

o controle da quantidade de água aplicada por irrigação foi realizado através de leituras em pluviômetros, instalados nos locais dos ensaios.

As plantas daninhas foram controladas através de capinas manuais. Quanto às pragas, o controle de percevejos (Nezara viridula, Euchistus heros e Piezodorus guildinii) foi efetuado por aplicações de inseticida clorado, à base de Endosulfan, na dosagem recomendada pelo fabricante, sempre que era encontrado um exemplar destes insetos, com $0,5 \mathrm{~cm}$ ou mais de comprimento por metro, em vistorias semanais, realizadas a partir do início da formação de vagens (R3), fase em que estes insetos começam a aparecer na lavoura (GAZONNI et al. 1981). 
o desenvolvimento das plantas foi acompanhado em cada experimento para a determinação dos estádios fenológicos, com ênfase para a fase reprodutiva avaliada de acordo com FEHR \& CAVINESS (1977).

Os períodos correspondentes ao ciclo da cultura, incluindo as datas de ocorrência dos estádios de desenvolvimento das plantas, observados para os cultivares de soja estudados, encontram-se nas Figuras 1, 2, 3 e 4 .

Com o objetivo de comparar parâmetros relacionados à produção de sementes em função das diferentes épocas e locais estudados, foram realizadas as seguintes avaliações:

Altura das plantas - quinze plantas tomadas ao acaso, de cada uma das três linhas sentrais de cada parcela, foram medidas ao atingirem o estádio de desenvolvimento R8. Foi anotada a distância (em centímetros) compreendida entre a superfície do solo e a gema apical de cada planta "e, em seguida, calculada a média das plantas obtidas para cada parcela.

Número de nós por planta - foi avaliado através da contagem do número de nós de quinze plantas, tomadas ao acaso, de cada uma das três linhas centrais de cada parcela, ao atingirem o estádio R8. Em seguida foi calculado o valor médio para cada parcela. 
Altura de inserção da primeira vagem - foi anotada a distância (em centímetros) entre a superfície do solo e a inserção das primeiras vagens em quinze plantas tomadas ao acaso, de cada uma das três linhas centrais de cada parcela, ao atingirem o estádio R8. Em seguida foi calculado o valor médio para cada parcela.

Número de vagens por planta - determinado mediante a contagem do número de vagens de quinze plantas tomadas ao acaso, de cada uma das três linhas centrais de cada parcela, ao atingirem o estádio R8. Em seguida foi calculado o valor médio para cada parcela.

A colheita foi realizada manualmente, desprezando-se, como bordadura, as duas linhas externas de cada parcela e 0,50m de cada extremidade das três linhas centrais, quando noventa e cinco por cento das vagens atingiram a coloração de vagens maduras, no estádio R8. Desta forma, a área útil colhida das parcelas foi de $7,5 \mathrm{~m}^{2}$. Após a debulha das sementes, também realizada manualmente, foi avaliada a produção final através da pesagem das sementes correspondentes à cada parcela, em balança com precisão de $0,1 \mathrm{~g}$; os valores obtidos foram transformados em $\mathrm{kg} / \mathrm{ha} e$ corrigidos, modificando-se o grau de umidade das sementes para 12\%, As sementes foram então embaladas em sacos de tela de algodão e armazenadas em condições normais de ambiente do armazém do Sistema de Produção de Sementes, localizado no Centro Experimental de Campinas/IAC. 
Os dados de umidade relativa e temperaturas máximas, mínimas e médias, referentes ao período de armazenamento, compreendido entre abril e dezembro de 1990, coletados no Posto Meteorológico desse Centro Experimental, encontram-se nas Figuras 5 e 6 .

\subsection{Avaliação da Qualidade das Sementes}

Visando avaliar a qualidade fisiológica e sanitária das sementes produzidas nas diferentes épocas e locais, os testes de laboratório foram realizados após a colheita, $E_{1}$ (no mês de maio de 1990 quando as sementes foram semeadas em $S_{1}$ e no mês de agosto de 1990 quando foram semeadas em $S_{2}$ ) e na época de semeadura da safra seguinte, $E_{2}$ (no mês de novembro de 1990).

A cleterminação do peso de mil sementes e as avaliações visuais de mancha púrpura, mancha café e de oósporos de Peronospora manshurica foram efetuadas apenas após a colheita.

\subsubsection{Peso de mil sementes}

Esta determinação foi realizada através da obtenção de 8 amostras de 100 sementes por repetição que, em seguida, foram pesadas com precisão de $0,01 \mathrm{~g}$. Os cálculos e a informação dos resultados foram efetuados de acordo com as Regras para Análise de Sementes (BRASIL, 1976). 


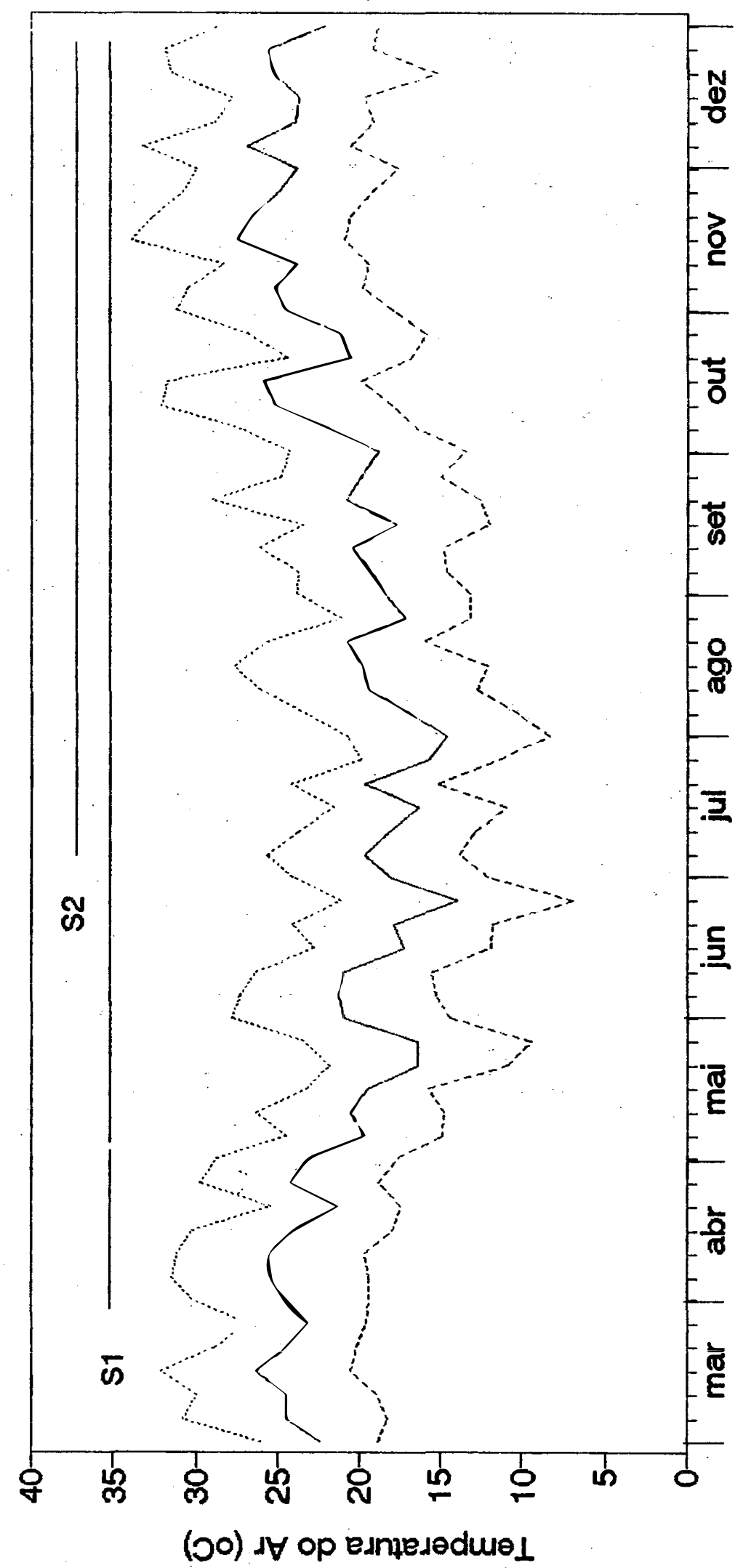

$\circ$ ه

(1) 응 건

द 00

ช० 검

忨爻川

N $N$

11 थ

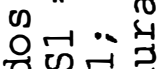

-

낭언

ब ने ఫु ह

क人 万人

○

म

थ क

兵问

$x$ 。

要 0

\&.न 0

유여

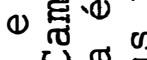

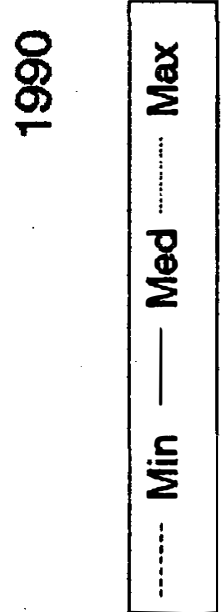

U

-

政

员

- 욤ำ

品足

-

告 क o :

E 0 过

द

(0) 0

㝳禀

फ ल

क्ष क o

(1) ๘

이

동 0

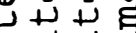

द

() 导 导

ర

द

क N N

О

ठㄹ ह

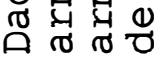

in

है 


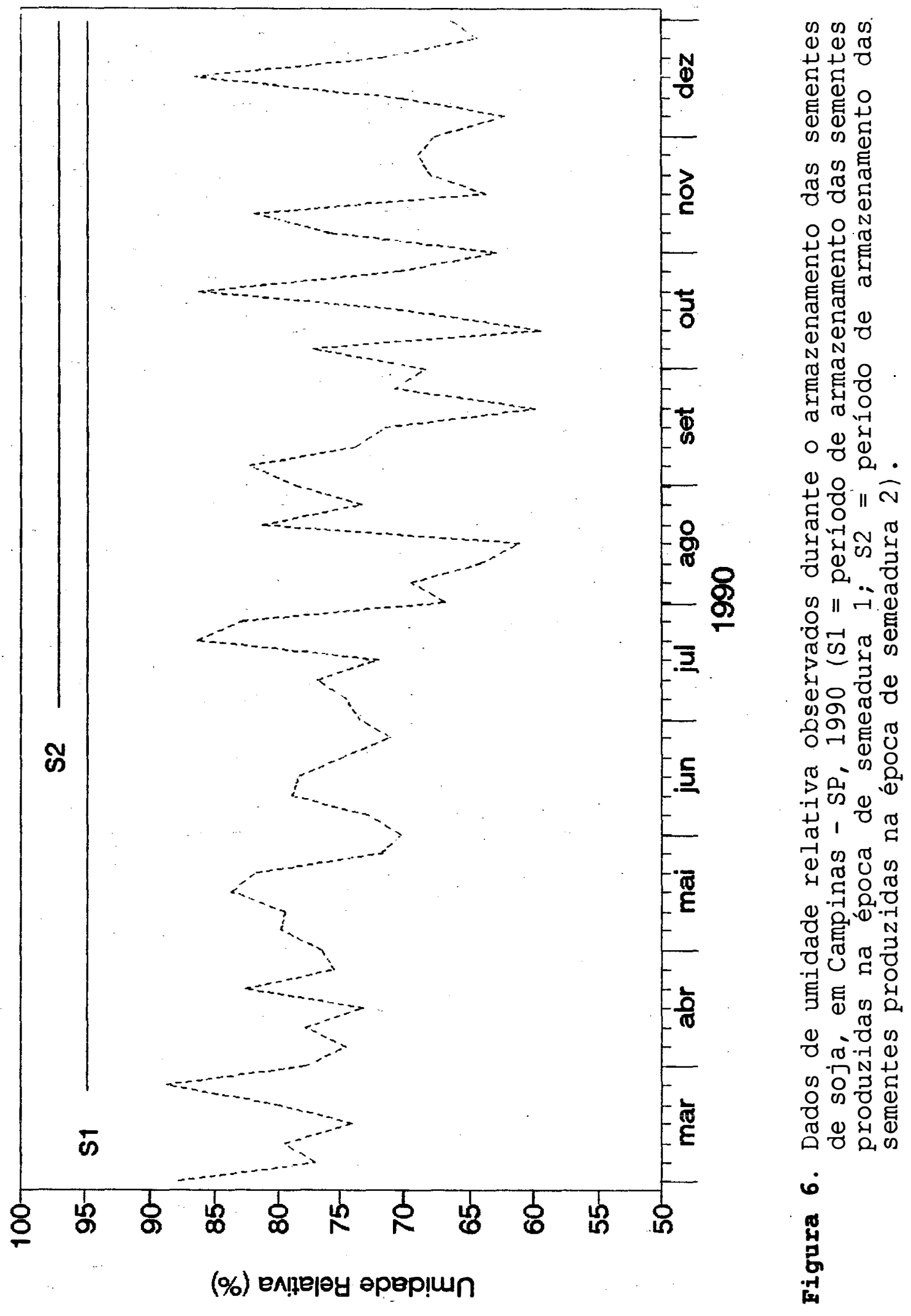




\subsubsection{Grau de umidade}

Foi efetuado em estufa a $105+$ ou $-3^{\circ} \mathrm{C}$ durante 24 horas, utilizando-se duas repetições de $50 \mathrm{~g}$ para cada tratamento, segundo prescrições das Regras para Análise de Sementes (BRASIL, 1976).

\subsubsection{Germinação}

Foi conduzido com duas amostras de cinqüenta sementes por repetição, semeadas em rolo de papel toalha Germitest, sob temperatura constante de $30^{\circ} \mathrm{C}$. O volume de água utilizado para a embebição foi equivalente a 2,5 vezes o peso do substrato. As porcentagens de plântulas normais foram avaliadas através de duas contagens: uma no quarto e outra no sétimo dia após a semeadura.

\subsubsection{Envelhecimento artificial}

Também conduzido com duas amostras de cinqüenta sementes por repetição, em caixas gerbox como compartimento individual (mini-câmaras), possuindo no seu interior uma bandeja de tela de aço inoxidável, onde foram distribuídas as sementes; no interior dessas mini-câmaras foram adicionados $40 \mathrm{ml}$ de água, e, a seguir, os gerbox adaptados foram mantidos a $42^{\circ} \mathrm{C}$, durante 48 horas, conforme metodologia sugerida por TAO (1979). 


\subsubsection{Condutividade elétrica}

Realizado com duas amostras de cinquienta sementes puras por repetição, de acordo com o método proposto por LOEFFLER et al. (1988); as sementes foram colocadas no interior de copos plásticos (diâmetro da base de $6 \mathrm{~cm}$ ) após pesagem (precisão de $0,01 \mathrm{~g}$ ); a cada copo foram adicionados $75 \mathrm{ml}$ de água destilada; as sementes imersas permaneceram em germinador a $25^{\circ} \mathrm{C}$, durante 24 horas. A condutividade da solução foi avaliada em condutivímetro e a média das amostras expressa em $\mu$ mhos $/ \mathrm{cm} / \mathrm{g}$.

\subsubsection{Tetrazólio}

Para esse teste foram empregadas duas amostras de cinqüenta sementes de cada repetição, précondicionadas em papel toalha umedecido e mantidas a $30^{\circ} \mathrm{C}$ em ambiente úmido (germinador), durante 16 horas. Decorrido esse período, as sementes foram transferidas para copinhos plásticos, imersas em solução a 0,075\% de sal de tetrazólio (cloreto de 2-3-5 trifenil tetrazólio) e mantidas durante 3 horas no interior de uma estufa a $40^{\circ} \mathrm{C}$. Após 0 desenvolvimento da coloração, as sementes foram lavadas em água corrente e avaliadas individualmente de acordo com a metologia proposta por MOORE (1962), sendo classificadas em níveis de 1 a 8 , segundo os critérios adotados por FRANÇA NETO et al. (1988). 
A viabilidade foi representada pela soma das porcentagens de sementes pertencentes às classes 1 a 5; o nível de vigor, através das classes 1 a 3 e a perda da viabilidade, pelas classes 6 a 8 . Foram caracterizadas também as causas de redução da qualidade das sementes devido a danos de deterioração por "umidade" e danos provocados por percevejos. Os resultados foram expressos em porcentagem.

\subsubsection{Sanidade}

\subsubsection{Teste do papel de filtro}

Foi realizado com duas amostras de cinqüenta sementes por repetição colocadas em placas de Petri de plástico transparente (10 sementes por placa), contendo três discos de papel de filtro de $80 \mathrm{~g} / \mathrm{m} 2$, previamente umedecidos em água destilada esterilizada. As sementes foram incubadas por sete dias a $22^{\circ} \mathrm{C}$, sob 12 horas de luz fluorescente e 12 horas no escuro, sendo em seguida examinadas ao estereomicroscópio para a determinação dos microrganismos a elas associados. A confirmação das espécies detectadas foi feita sob microscópio composto, de acordo com a morfologia dos conídios (BRASIL, 1976). 


\subsubsection{Avaliações visuais}

As avaliações de sementes com mancha púrpura, mancha café e com oósporos de Peronospora manshurica foram efetuadas em amostras de $500 \mathrm{~g}$ de sementes por repetição. Os resultados foram expressos em peso $(g)$ de sementes infectadas por $100 \mathrm{~g}$ de sementes.

\subsection{Teste de Emergência de Plântulas}

Foi conduzido em campo, onde foram semeadas duas amostras de cinqüenta sementes por repetição; cada uma foi distribuída em sulco com $2 \mathrm{~m}$ de comprimento e 0,02m de profundidade, mantendo-se as sementes eqüidistantes; cada sulco distou $0,50 \mathrm{~m}$ do outro. Realizaram-se contagens aos quinze dias após a semeadura, computando-se as porcentagen: de emergência. Foram conduzidos três testes na épocá recomendada para semeadura da soja no Estado de São Paulo (primeira e segunda quinzenas de novembro e primeira quinzena de dezembro de 1990) .

\subsection{Produção de Sementes Viáveis}

Os dados referentes à produção de sementes viáveis foram calculados para cada parcela, multiplicandose o valor de produção ( $\mathrm{kg} / \mathrm{ha}$ ) pelos valores de germinação (\%) das sementes, obtidos após a colheita $\left(E_{1}\right)$ e na época da semeadura da safra seguinte $\left(E_{2}\right)$. 


\subsection{Procedimento Estatístico}

Os dados obtidos nos testes de germinação, tetrazólio, envelhecimento artificial e emergência de plântulas em campo foram transformados em arc sen $\sqrt{\text { ô100, }}$ enquanto que os referentes à condutividade elétrica, peso de mil sementes, aos parâmetros determinados nos ensaios de campo e à produção de sementes viáveis não foram transformados. Os dados correspondentes ao grau de umidade das sementes e à sanidade não foram analisados estatisticamente.

A análise de variância foi realizada separadamente para cada cultivar e avaliação, para cada época de amostragem $\left(\begin{array}{llll}E_{1} & e & E_{2}\end{array}\right)$ no caso dos testes de laboratório e para cada teste de emergência de plântulas em campo. O delineamento experimental foi 0 de blocos casualizados, com cinco repetições em esquema fatorial (dois locais $\mathrm{x}$ duas épocas de semeadura), especificado na Tabela 3.

Nos casos onde a interação épocas de semeadura $x$ locais foi significativa, realizou-se 0 desdobramento dos graus de liberdade para verificar os efeitos de épocas de semeadura dentro de local e de locais dentro de época de semeadura. 
Tabela 3. Esquema da análise de variância para cada cultivar, com os dados obtidos nos ensaios de campo, nos testes de laboratório e emergências de plântulas no campo.

Causas de variaçăo

Épocas de Semeadura

Locais

Épocas de Semeadura $\times$ Locais

(Tratamentos)

Blocos

Resíduo

Total

\section{Graus de Liberdade}

(3)

4

12

A comparação entre as médias foi efetuada pelo teste de Tukey ao nível de $5 \%$ de probabilidade. Considerando-se apenas o teste de condutividade elétrica, quando as diferenças entre médias foram significativas, empregou-se a letra A para os menores valores, por significarem melhor qualidade fisiológica das sementes.

Os cálculos referentes à análise estatística foram realiżados na Seção de Cálculo e Técnica Experimental do IAC, empregando-se o Programa Statistical Analysis Sistem (SAS, 1993).

Os dados de sanidade, obtidos através do teste do papel de filtro e não analisados estatisticamente, foram representados na forma de histrogramas. 


\section{RESULTADOS E DISCUSSÃO}

\subsection{Fenologia}

Nas Figuras 1 e 2 encontram-se os dados de temperaturas máximas e mínimas e de precipitação pluvial diárias, além das datas de ocorrência dos estádios fenológicos das plantas de soja, observadas para os cinco cultivares estudados ('IAC-100', 'IAC-16', 'IAC-Foscarin31', 'BR-4' e 'IAS-5') quando a semeadura foi efetuada na época convencional $\left(S_{1}\right)$ em Campinas (29/11/89) e Votuporanga (20/11/89), respectivamente.

As Figuras 3 e 4 contém os mesmios parâmetros verificados na época de semeadura tardia $\left(S_{2}\right)$, em Campinas (27/03/90) e Votuporanga (03/04/90), respectivamente.

Examinando-se a Figura 1, pode-se constatar que na época normalmente recomendada para a semeadura da soja no Estado de São Paulo $\left(\mathrm{S}_{1}\right)$, o ciclo da cultura foi de 119 dias para os cultivares 'IAC-100' e 'IAC-16', de 114 dias para O 'IAC-Foscarin-31', 116 dias para O 'BR-4' e 111 dias para o 'IAS-5', em Campinas. Esses dados coincidiram com os da descrição destes cultivares encontrada na Tabela 1. 
Observando-se os dados de temperatura (Figura 1), nota-se que esta se manteve relativamente alta durante todo o ciclo da cultura. A temperatura máxima variou entre 23 e $34^{\circ} \mathrm{C}$, mantendo-se elevada, com maior frequiência, no período que coincidiu com a fase reprodutiva da cultura.

A temperatura mínima variou entre 14 e $22^{\circ} \mathrm{C}$ na fase vegetativa e entre 17 e $23^{\circ} \mathrm{C}$ na fase reprodutiva, apresentando variações menores nessa última fase.

Segundo MARCOS FILHO (1986), são consideradas aptas à cultura da soja, as regiões que apresentam boa distribuição de precipitações pluviais (500 a $700 \mathrm{~mm}$ ) durante o ciclo das plantas. Analisando-se os dados de precipitação pluvial (Figura 1), verifica-se que a região de Campinas foi adequada à cultura da soja em $\mathrm{S}_{1}$, apresentando um volume total de chuvas de $960 \mathrm{~mm}$ no período de condução do experimento, distribuidas com maior frequiência durante a fase vegetativa da cultura.

Em Votuporanga (Figura 2), o ciclo da cultura foi de 111, 115, 108, 110 e 107 dias para os cultivares 'IAC-100', 'IAC-16', 'IAC-Foscarin-31', 'BR-4' e 'IAS-5', respectivamente, significando uma redução de ciclo entre 4 e 8 dias, conforme o cultivar, em comparação à Campinas na mesma época de semeadura $\left(\mathrm{S}_{1}\right)$.

Observando-se a duração da fase vegetativa, constata-se que a redução no ciclo da cultura em Votuporanga deveu-se à antecipação do florescimento em 11 a 12 dias em relação à Campinas. Por outro lado, a fase reprodutiva foi relativamente mais longa em Votuporanga. 
o principal fator de adaptação de uma variedade de soja a uma região é sua resposta fotoperiódica (HARTWIG, 1954), responsável pela duração do ciclo biológico dos cultivares de soja (REMUSSI \& PASCALE, citados por MOTA, 1983). Com a localização do experimento em Votuporanga, situada em menor latitude em comparação à Campinas, provavelmente o fotoperíodo crítico para os cultivares incluídos na pesquisa ocorreu mais cedo, resultando na antecipação do florescimento naquela região em $S_{1}$.

Em Votuporanga (Figura 2), a temperatura também foi elevada durante todo o ciclo da cultura em $\mathrm{S}_{1}$, porém, alcançando níveis maiores em relação à Campinas; a temperatura máxima manteve-se com maior freqüência entre 30 e $34^{\circ} \mathrm{C}$, atingindo $36^{\circ} \mathrm{C}$ na fase reprodutiva; a temperatura mínima variou entre 17 e $24^{\circ} \mathrm{C}$ na fase vegetativa e entre 19 e $23^{\circ} \mathrm{C}$ na fase reprodutiva.

Associadas a fotoperíodos mais curtos, as temperaturas mais altas observadas em Votuporanga podem ter contribuído para a antecipação do florescimento nesta região em comparação à Campinas. Na literatura, diversos autores discutiram as possíveis modificações das respostas fotoperiódicas da soja relacionadas aos efeitos da temperatura (WHIGHAM \& MINOR, 1967; MAJOR et al., 1975; BERGAMASCHI et al., 1977 e NAKAGAWA et al., 1983). 
Analisando-se os dados de precipitação pluvial (Figura 2), nota-se que Votuporanga também foi apta à cultura da soja, apresentando $861 \mathrm{~mm}$ em volume total de chuvas durante a condução do experimento na época convencional $\left(S_{1}\right)$, distribuídos com maior freqüência na fase vegetativa da cultura.

Diversos autores relataram que o atraso da semeadura em relação à época mais apropriada à cultura da soja reduz, principalmente, o período entre a emergência das plântulas e o florescimento, em extensão variável, conforme o ciclo de maturação do cultivar (FEASTER, 1949; ABEL, 1961; NICHOLSON \& SINCLAIR, 1973; NAKAGAWA et al., 1983 e JOHNSON, 1987). Os dias mais curtos, característicos nas semeaduras tardias antecipam o alcance do fotoperíodo crítico levando ao florescimento precoce.

Este fato também se revelou na presente pesquisa, de forma que a semeadura realizada no mês de março $\left(S_{2}\right)$ em Campinas (Figura 3 ) resultou na redução do ciclo da cultura em 12 a 18 dias, conforme o cultivar, devido principalmente à antecipação do florescimento em comparação à semeadura conduzida na época convencional $\left(S_{1}\right)$. O intervalo entre o início do florescimento (R1) e o início da formação de vagens (R3) também foi de 5 a 7 dias mais curto em $S_{2}$ do que em $S_{1}$. Entretanto, considerando-se integralmente a duração da fase reprodutiva da cultura, compreendida entre os estádios R1 e R8 (noventa e cinco por cento das vagens com coloração padrão do respectivo cultivar), não se observaram diferenças consistentes entre as duas épocas de semeadura. 
Constatou-se nesse experimento (Figura 3), a queda de temperatura desde o início até o final do ciclo da cultura; na fase vegetativa a temperatura máxima variou entre 20 e $33^{\circ} \mathrm{C}$ e na fase reprodutiva entre 17 e $28^{\circ} \mathrm{C}$; a temperatura mínima situou-se entre 14 e $21^{\circ} \mathrm{C}$ na fase vegetativa e entre 3 e $17^{\circ} \mathrm{C}$ na fase reprodutiva.

Os possíveis efeitos retardadores das temperaturas mais baixas observadas na semeadura tardia em Campinas sobre a ocorrência dos estádios fenológicos da cultura foram superados pelos dias curtos que aceleraram nitidamente a maturação, confirmando o comentário de MAJOR et al. (1975) .

Devido ao pequeno volume total de chuvas (143 mm) verificado nesta época $\left(\mathrm{S}_{2}\right)$ em Campinas (Figura 3), a condução do experimento viabilizou-se apenas sob irrigação suplementar. Evidenciou-se o período seco coincidente com a fase reprodutiva da cultura.

Em Votuporanga (Figura 4), a redução do ciclo da cultura constatada na semeadura tardia $\left(S_{2}\right)$ em comparação à efetuada na época convencional $\left(S_{1}\right)$ foi ainda mais acentuada em relação à Campinas, variando entre 13 e 31 dias, dependendo do cultivar.

Ao contrário do que aconteceu em Campinas, no entanto, a redução no ciclo dos cultivares 'IAC-16' e 'IAS-5', devida ao atraso da semeadura $\left(S_{2}\right)$, concentrou-se praticamente na fase reprodutiva, enquanto que, para os cultivares 'IAC-100', 'IAC-Foscarin-31' e 'BR-4' foi 
distribuída entre a fase vegetativa e a reprodutiva. A redução da fase reprodutiva em conseqüência de semeaduras tardias também foi mencionada na literatura (FEASTER, 1949; HARTWIG, 1954; ABEL, 1961 e ATHAYDE et al., 1984).

Em Votuporanga (Figura 4), também foi observada queda da temperatura durante a condução do experimento na época de semeadura tardia $\left(S_{2}\right)$; na fase vegetativa, a temperatura máxima variou entre 20 e $33^{\circ} \mathrm{C}$ e na reprodutiva entre 18 e $32^{\circ} \mathrm{C}$; a temperatura mínima variou entre 17 e $22^{\circ} \mathrm{C}$ na fase vegetativa e entre 4 e $19^{\circ} \mathrm{C}$ na reprodutiva.

Nesta época $\left(S_{2}\right)$, o volume total de chuvas constatado em Votuporanga $(179 \mathrm{~mm})$ também teria sido insuficiente para a condução da cultura sem a suplementação de água por irrigação. O período seco, coincidente com a fase reprodutiva, mostrou-se mais acentuado ainda em relação à Campinas na mesma época.

\subsection{Características Agronômicas}

Os níveis de significância relativos dos valores de $\mathrm{F}$ obtidos nas análises de variância dos dados referentes às características agronômicas encontram-se na Tabela 4. 
Tabela 4. Níveis de significância dos valores de F obtidos nas análises de variância dos dados referentes às características agronômicas estudadas.

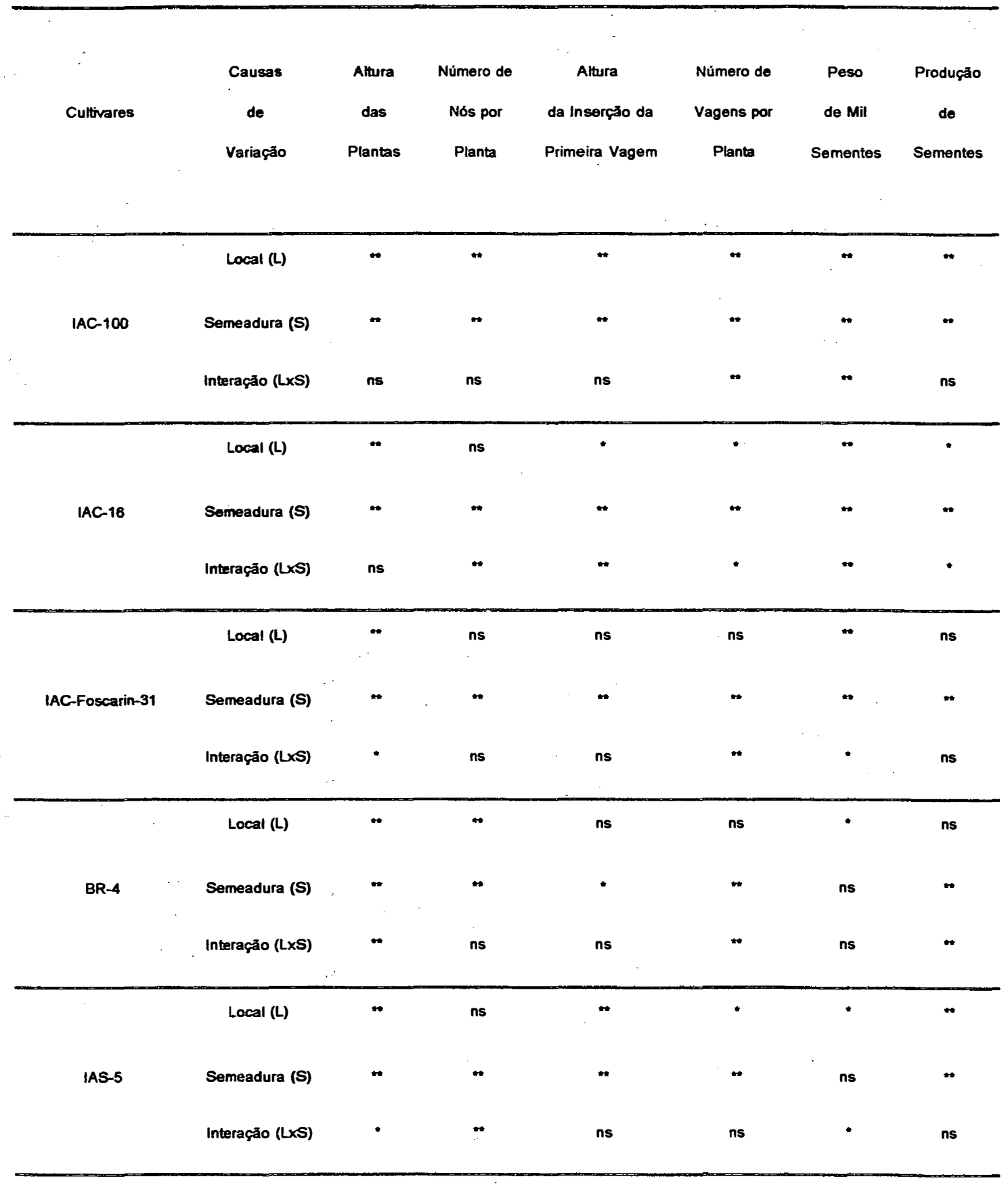

ns não significativo

* significativo ao nível de 5\% de probabilidade.

** significativo ao nível de $1 \%$ de probabilidade. 


\subsubsection{Altura das plantas}

Analisando-se a Tabela 5, verifica-se, para os cinco cultivares estudados, a superioridade da altura das plantas de Campinas em comparação à Votuporanga, quando a semeadura foi efetuada na época convencional $\left(S_{1}\right)$.

Sendo o porte da planta de soja condicionado à duração do período vegetativo (HANWAY \& THOMPSON 1971), acredita-se que a antecipação do florescimento (l1 a 12 dias) observada em Votuporanga (Figura 1) em comparação à Campinas (Figura 2), nesta época $\left(S_{1}\right)$, resultou em plantas mais baixas naquela região.

Verifica-se ainda maior ocorrência de temperaturas elevadas coincidindo com a fase vegetativa da cultura em Votuporanga (Figura 2), onde a temperatura máxima diária manteve-se com maior freqüêncià entre 30 e $34^{\circ} \mathrm{C}$. De acordo com BARNI et al. (1978) e MARCOS FILHO (1986), temperaturas acima de $30^{\circ} \mathrm{C}$ podem exercer efeito depressivo sobre a intensidade de desenvolvimento das plantas, podendo inclusive, inibir a nodulação. Este fato também pode ter contribuído para a obtenção de plantas mais baixas em Votuporanga.

Outro fator que pode ter favorecido a superioridade da altura das plantas em Campinas foi a maior fertilidade do solo constatada nesta localidade, inclusive, apresentando maior teor de matéria orgânica (Tabela 2), embora a correção e a adubação dos locais dos ensaios, nos dois municípios, tenha sido efetuada de acordo com as recomendações de VAN RAIJ et al. (1985) • 
Tabela 5. Altura das plantas no estádio R8: valores médios (cm) obtidos para cada cultivar de soja, em função de épocas e locais de semeadura.

\begin{tabular}{lcccc}
\hline Cultivares & Épocas de Semeadura & Campinas & Votuporanga & Médias \\
\hline \multirow{2}{*}{ IAC-100 } & $\mathrm{S}_{1}$ & 87,9 & 65,5 & $76,7 \mathrm{~A}$ \\
& $\mathrm{~S}_{2}$ & 43,2 & 28,3 & $35,8 \mathrm{~B}$ \\
\hline Médias & & $65,6 \mathrm{a}$ & $46,9 \mathrm{~b}$ & \\
\hline C.V. \% & 11,68 & & \\
\hline & $\mathrm{S}_{1}$ & 104,7 & 97,7 & $101,2 \mathrm{~A}$
\end{tabular}

IAC-16

\begin{tabular}{lcccc} 
& $S_{2}$ & 42,1 & 30,7 & 36,4 B \\
\hline Médias & 73,4 a & 64,2 b & \\
\hline C.V. \% & 5,87 & & \\
\hline & $S_{1}$ & 104,6 Aa & $88,2 \mathrm{Ab}$ & 96,4
\end{tabular}

IAC-Foscarin-31

\begin{tabular}{lcccc} 
& $\mathrm{S}_{2}$ & $31,9 \mathrm{Ba}$ & $27,9 \mathrm{Ba}$ & 29,9 \\
\hline Médias & & 68,3 & 58,1 & \\
\hline C.V. \% & & 10,80 & & \\
\hline & $\mathrm{S}_{1}$ & $80,5 \mathrm{Aa}$ & $52,5 \mathrm{Ab}$ & 66,5
\end{tabular}

BR-4

\begin{tabular}{lcccc} 
& $S_{2}$ & $36,7 \mathrm{Ba}$ & $30,0 \mathrm{Ba}$ & 33,4 \\
\hline Médias & 58,6 & 41,3 & \\
\hline C.V. $\%$ & & 13,47 & & \\
\hline & $S_{1}$ & $63,6 \mathrm{Aa}$ & $44,6 \mathrm{Ab}$ & 54,1
\end{tabular}

IAS-5

\begin{tabular}{lcccc} 
& $\mathrm{S}_{2}$ & $33,7 \mathrm{Ba}$ & $27,7 \mathrm{Ba}$ & 30,7 \\
\hline Médias & 48,7 & 36,2 & \\
\hline C.V. \% & 11,46 & & \\
\hline
\end{tabular}

* Para cada cultivar, as médias da mesma coluna seguidas pela mesma letra maiúscula ou da mesma linha seguidas pela mesma letra minúscula não diferiram entre si, ao nível de 5\% de probabilidade, pelo teste de Tukey. 
Comparando-se as duas épocas de semeadura, observa-se que a altura final das plantas de todos os cultivares incluídos na pesquisa diminuiu na semeadura tardia $\left(S_{2}\right)$, em conseqüência do florescimento precoce constatado nesta época nos dois locais estudados, concordando com as informações registradas na literatura IOSLER \& CARTER， 1954; TORRIE \& BRIGS, 1955; ABEL, 1961; GRAVES et al., 1978; PAYNE et al., 1978; SANCHEZ \& YUYAMA, 1979; TRAGNAGO \& BONETTI, 1984 e BOARD \& SETTIMI, 1986). Por outro lado, a redução do intervalo entre os estádios R1 e R3 em Campinas e entre os estádios R1 e R7 em Votuporanga, quando se realizou a semeadura tardia $\left(S_{2}\right)$, também podem ter contribuído para a redução da altura das plantas nesta época. BOARD \& SETTIMI (1986), nos Estados Unidos, constatarain que aproximadamente $2 / 3$ do número e comprimento totais de ramos eram produzidos entre o início do florescimento (R1) e o início do desenvolvimento das sementes (R5).

Observa-se ainda que os cultivares de hábito de crescimento indeterminado (IAC-16 e IAC-Foscarin-31), que haviam produzido as plantas mais altas em $S_{1}$ nos dois locais, foram os que sofreram maior redução de altura de plantas em $\mathrm{S}_{2}$; a diferença entre cultivares quanto a este parâmetro também se reduziu nesta época, tornando-se quase nula em Votuporanga, confirmando os resultados obtidos por ABEL (1961). 
Na semeadura tardia $\left(S_{2}\right)$, a antecipação do florescimento reduziu as diferenças de duração do período vegetativo entre Campinas e Votuporanga, diminuindo conseqüentemente, as diferenças quanto a altura das plantas produzidas nos dois locais, de forma que, embora os valores numéricos das médias de altura de plantas tenham sido superiores em Campinas para todos os cultivares, a análise estatística revelou diferenças significativas entre os dois locais para este parâmetro, apenas para os cultivares 'IAC100' e 'IAC-16'.

\subsubsection{Número de nós por planta}

Os níveis de significância relativos aos valores de $\mathrm{F}$ encontrados na Tabela 4 revelam que os efeitos de local sobre o número de nós por planta foram menos evidentes do que sobre altura de plantas. Apenas os cultivares 'IAC-100' e 'BR-4' apresentaram número de nós por planta significativamente superiores em Campinas em relação à Votuporanga em $S_{1}$ e $S_{2}$, conforme pode-se observar examinando-se a Tabela 6 . O cultivar IAC-Foscarin-31 não apresentou diferenças significativas quanto a este parâmetro entre os dois locais estudados nas duas épocas de semeadura; as plantas do cultivar IAC-16 apresentaram maior número de nós em Votuporanga em $\mathrm{S}_{1} \mathrm{e}$ em Campinas em $\mathrm{S}_{2}$, enquanto que, as do cultivar IAS-5 mostraram o inverso. 
Tabela 6. Número de nós por planta no estádio R8: valores médios obtidos para cada cultivar de soja, em função de épocas e locais de semeadura.

\begin{tabular}{ccccc}
\hline Cultivares & Épocas de Semeadura & Campinas & Votuporanga & Médias \\
\hline$S_{1}$ & 14,8 & 14,2 & $14,5 \mathrm{~A}$
\end{tabular}

IAC-100

\begin{tabular}{lcccc} 
& $S_{2}$ & 9,8 & 8,8 & $9,3 \mathrm{~B}$ \\
\hline Médias & & $12,3 \mathrm{a}$ & $11,5 \mathrm{~b}$ & \\
\hline C.V. \% & 4,13 & & \\
\hline & $S_{1}$ & $16,4 \mathrm{Ab}$ & $18,6 \mathrm{Aa}$ & 17,5
\end{tabular}

IAC-16

\begin{tabular}{lcccc} 
& $S_{2}$ & $10,0 \mathrm{Ba}$ & $8,6 \mathrm{Bb}$ & 9,3 \\
\hline Médias & & 13,2 & 13,6 & \\
\hline C.V. \% & & 4,20 & & \\
\hline & $S_{1}$ & 17,0 & 16,8 & $16,9 \mathrm{~A}$
\end{tabular}

IAC-Foscarin-31

\begin{tabular}{lcccc} 
& $S_{2}$ & 8,8 & 9,2 & $9,0 \mathrm{~B}$ \\
\hline Médias & $12,9 \mathrm{a}$ & $13,0 \mathrm{a}$ & \\
\hline C.V. \% & & 4,83 & & \\
\hline & $\mathrm{S}_{1}$ & 14,0 & 13,4 & $13,7 \mathrm{~A}$
\end{tabular}

BR-4

\begin{tabular}{lcccc} 
& $S_{2}$ & 9,0 & 8,4 & $8,7 \mathrm{~B}$ \\
\hline Médias & & $11,5 \mathrm{a}$ & $10,9 \mathrm{~b}$ & \\
\hline C.V. \% & & 3,36 & & \\
\hline & $\mathrm{S}_{1}$ & $12,2 \mathrm{Aa}$ & $11,4 \mathrm{Ab}$ & 11,8
\end{tabular}

IAS-5

\begin{tabular}{lcccc} 
& $S_{2}$ & $8,0 \mathrm{Bb}$ & $9,4 \mathrm{Ba}$ & 8,7 \\
\hline Médias & 10,1 & 10,4 & \\
\hline C.V. \% & 4,63 & \\
\hline
\end{tabular}

* Para cada cultivar, as médias da mesma coluna seguidas pela mesma letra maiúscula ou da mesma linha seguidas pela mesma letra minúscula não diferiram entre si, ao nível de 5\% de probabilidade, pelo teste de Tukey. 
Estes resultados sugerem que a altura das plantas não foi condicionada exclusivamente ao número de nós formado na. planta, mas também ao comprimento dos internódios. Possivelmente, o efeito depressivo das temperaturas elevadas, encontradas em Votuporanga em $\mathrm{S}_{1}$, ocorreu com maior intensidade sobre o crescimento dos internódios do que sobre a formação de nós nas plantas de soja.

No entanto, de acordo com VERNETTI. (1983) e TRAGNAGO \& BONETTI (1984), quanto mais tardia é a semeadura, menor é o número de nós formado na planta, proporcionalmente à redução no ciclo da cultura. Este fato roi evidenciado na presente pesquisa, para todos os cultivares e nos dois locais estudados, o que pode ser observado comparando-se a semeadura tardia $\left(\mathrm{S}_{2}\right)$ à realizada na época tradicional $\left(S_{1}\right)$. Os cultivares de hábito de crescimento indeterminado ('IAC-16' e 'IAC-Foscarin-31'), foram os que sofreram maior redução quanto ao número de nós por planta, quando se conduziu a semeadura tardia nos dois locais. Dessa forma, em $\mathrm{S}_{2}$, à semelhança do que se verificou para altura de plantas, a diferenciação entre cultivares quanto ao número de nós por planta também foi reduzida. 


\subsubsection{Altura da inserção da primeira vagem}

Esta característica agronômica está diretamente relacionada à operação de colheita das sementes de soja. Segundo QUEIROZ et al.(1981), a altura da inserção das primeiras vagens deve ser de no mínimo $13 \mathrm{~cm}$, para que seja reduzida a perda de sementes durante a colheita mecânica .

Observando-se a Tabela 7 constata-se que em $\mathrm{S}_{1}$, praticamente todos os cultivares apresentaram médias para este parâmetro compatíveis com a colheita mecânica, com exceção apenas do 'IAS-5' em Votuporanga. Na semeadura tardia $\left(S_{2}\right)$, nenhum cultivar apresentou médias para altura da inserção da primeira vagem igual ou superior a $13 \mathrm{~cm}$; apenas o cultivar 'IAS-5' em Campinas apresentou média próxima a este valor. Este fato está associado à altura de plantas ter sido inferior a $50 \mathrm{~cm}$ nesta época, o que para QUEIROZ (1981) e MARCOS FILHO (1986) favorece a formação de vagens muito próximas do solo.

o fato de ter sido verificada redução na altura da inserção da primeira vagem das plantas, simultaneamente à menor altura das plantas para todos os cultivares nos dois locais, quando se efetuou a semeadura tardia (S2); confirma os comentários de BARNI et al. (1978) e de VERNETTI (1983) . 
Tabela 7. Altura da inserção da primeira vagem no estádio R8: valores médios. (cm) obtidos para cada cultivar de soja, em função de épocas e locais de semeadura.

\begin{tabular}{lcccc}
\hline Cultivares & Épocas de Semeadura & Campinas & Votuporanga & Médias \\
\hline \multirow{2}{*}{ IAC-100 } & $\mathrm{S}_{1}$ & 17,0 & 14,1 & $15,6 \mathrm{~A}$ \\
& $\mathrm{~S}_{2}$ & 12,2 & 8,3 & $10,3 \mathrm{~B}$ \\
\hline Médias & & $14,6 \mathrm{a}$ & $11,2 \mathrm{~b}$ & \\
\hline C.V. \% & & 13,21 & & \\
\hline & $\mathrm{S}_{1}$ & $15,5 \mathrm{Ab}$ & $20,4 \mathrm{Aa}$ & 18,0
\end{tabular}

IAC:16

\begin{tabular}{|c|c|c|c|c|}
\hline & $S_{2}$ & $11,4 \mathrm{Ba}$ & $11,0 \mathrm{Ba}$ & 11,2 \\
\hline Médias & & 13,5 & 15,7 & \\
\hline C.V. $\%$ & & 11,74 & & \\
\hline & $s_{1}$ & 18,1 & 18,0 & $18,1 \mathrm{~A}$ \\
\hline
\end{tabular}

IAC-Foscarin-31

\begin{tabular}{|c|c|c|c|c|}
\hline & $S_{2}$ & 9,0 & 80 & $8,5 \mathrm{~B}$ \\
\hline Médias & & $13,6 a$ & $13,0 \mathrm{a}$ & \\
\hline C.V. \% & & 14,96 & & \\
\hline & $\mathrm{s}_{1}$ & 12,9 & 13,2 & $13,1 \mathrm{~A}$ \\
\hline
\end{tabular}

BR-4

\begin{tabular}{ccccc} 
& $S_{2}$ & 12,2 & 10,6 & $11,4 \mathrm{~B}$ \\
\hline Médias & & 12,6 a & 11,9 a & \\
\hline C.V. \% & & 11,80 & & \\
\hline & $s_{1}$ & 19,7 & 11,2 & $15,5 \mathrm{~A}$
\end{tabular}

IAS-5

\begin{tabular}{lcccc} 
& $\mathrm{S}_{2}$ & 12,9 & 9,1 & $11,0 \mathrm{~B}$ \\
\hline Médias & $16,3 \mathrm{a}$ & $10,2 \mathrm{~b}$ \\
\hline C.V. \% & 11,81 & \\
\hline
\end{tabular}

* Para cada cultivar, as médias da mesma coluna seguidas pela mesma letra maiúscula ou da mesma linha seguidas pela mesma letra minúscula não diferiram entre si, ao nível de 5\% de probabilidade, pelo teste de Tukey. 
Ainda, cabe salientar que, embora em $\mathrm{S}_{1}$ as médias de altura da inserção da primeira vagem tenham sido mais compativeis com a colheita mecânica, constatou-se, principalmente em Campinas, acamamento acentuado das plantas para os cultivares 'BR-4' e 'IAC-100' e em menor nivel para O 'IAC-16' e 'IAC-Foscarin-31'. De acordo com MARCOS FILHO (1986), esta é uma das principais causas da perda de sementes durante a colheita mecânica: plantas deitadas não são recolhidas pela máquina.

\subsubsection{Número de vagens por planta}

Este parâmetro é tido como o principal fator que controla o rendimento da cultura da soja (DIMMOCK \& WARREN， 1953; CARTER， 1974; VERNETTI, 1983; TRAGNAG） \& BONETTI, 1984 e BOARD, 1987).

Pelo exame da Tabela 8 , observa-se que em $S_{1}$ não houve diferenças significativas quanto ao número de vagens por planta entre os locais estudados, considerandose os cultivares 'IAC-100' e 'IAC-16'; para os cultivares 'IAC-Foscarin-31' e 'BR-4', as médias foram inferiores em Campinas e para o 'IAS-5' a média foi inferior em Votuporanga. Nota-se, ainda que, apenas o cultivar IAS-5 apresentou número de vagens estreitamente relacionado tanto à altura quanto ao número de nós por planta, comparando-se os dois locais. 
Tabela 8. Número de vagens por planta no estádio R8: valores médios obtidos para cada cultivar de soja, em função de épocas e locais de semeadura.

\begin{tabular}{ccccc}
\hline Cultivares & Épocas de Semeadura & Campinas & Votuporanga & Médias \\
\hline$S_{1}$ & $43,8 \mathrm{Aa}$ & $41,0 \mathrm{Aa}$ & 42,4
\end{tabular}

IAC-100

\begin{tabular}{ccccc} 
& $S_{2}$ & $25,0 \mathrm{Ba}$ & $13,2 \mathrm{Bb}$ & 19,1 \\
\hline Médias & 34,4 & 27,1 & \\
\hline C.V. \% & 10,42 & & \\
\hline & $S_{1}$ & $35,4 \mathrm{Aa}$ & 36,4 Aa & 35,9
\end{tabular}

IAC-16

\begin{tabular}{lcccc} 
& $\mathrm{S}_{2}$ & $22,8 \mathrm{Ba}$ & $11,6 \mathrm{Bb}$ & 17,2 \\
\hline Médias & & 29,1 & 24,0 & \\
\hline C.V. \% & 18,09 & & \\
\hline & $\mathrm{S}_{1}$ & $30,0 \mathrm{Ab}$ & $34,4 \mathrm{Aa}$ & 32,2
\end{tabular}

IAC-Foscarin-31

\begin{tabular}{lcccc} 
& $\mathrm{S}_{2}$ & $18,8 \mathrm{Ba}$ & $12,6 \mathrm{Bb}$ & 15,7 \\
\hline Médias & \multicolumn{1}{c}{24,4} & 23,5 & \\
\hline C.V. \% & 11,47 & & \\
\hline & $\mathrm{S}_{1}$ & $36,6 \mathrm{Ab}$ & $42,0 \mathrm{Aa}$ & 39,3
\end{tabular}

BR-4

\begin{tabular}{lcccc} 
& $\mathrm{S}_{2}$ & $23,2 \mathrm{Ba}$ & $13,8 \mathrm{Bb}$ & 18,5 \\
\hline Médias & & 29,9 & 27,9 & \\
\hline C.V. \% & & 13,38 & & \\
\hline & $\mathrm{S}_{1}$ & 31,2 & 26,0 & $28,6 \mathrm{~A}$
\end{tabular}

IAS-5

\begin{tabular}{lcccc} 
& $\mathrm{S}_{2}$ & 17,8 & 13,0 & 15,4 B \\
\hline Médias & 24,5 a & 19,5 b \\
\hline C.V. \% & 17,41 & & \\
\hline
\end{tabular}

* Para cada cultivar, as médias da mesma coluna seguidas pela mesma letra maiúscula ou da mesma linha seguidas pela mesma letra minúscula não diferiram entre si, ao nível de 5\% de probabilidade, pelo teste de Tukey. 
Considerando-se $S_{2}$, verifica-se que as médias de número de vagens por planta obtidas em Campinas superaram significativamente as de Votuporanga para os cinco cultivares "estudados, acompanhando os valores numéricos das médias de altura de plantas, que também foram superiores em Campinas nesta época. No entanto, apenas os cultivares 'IAC-100', 'IAC-16' e 'BR-4' apresentaram plantas com número de vagens proporcional ao número de nós, comparando-se essas duas localidades.

Por outro lado, comparando-se épocas de semeadura, constata-se que o número de vagens por planta foi acentuadamente reduzido na semeadura tardia $\left(S_{2}\right)$ para todos os cultivares, nos dois locais, proporcionalmente tanto à altura quanto ao número de nós por planta verificados nesta época, concordando com VERNETTI (1983) e TRAGNAGO \& BONETTI (1984).

\subsubsection{Peso de mil sementes}

Analisando-se a Tabela 9, observa-se que as sementes produzidas em Campinas em $S_{1}$ apresentaram-se mais pesadas do que as obtidas em Votuporanga, exceto para o cultivar $\mathrm{BR}-4$ 
Tabela 9. Peso de mil sementes: valores médios ( $g$ ) obtidos para cada cultivar de soja, em função de épocas e locais de semeadura.

\begin{tabular}{ccccc}
\hline Cultivares & Épocas de Semeadura & Campinas & Votuporanga & Médias \\
\hline$S_{1}$ & $116,5 \mathrm{Aa}$ & $81,8 \mathrm{Bb}$ & 99,2
\end{tabular}

IAC-100

\begin{tabular}{lcccc} 
& $S_{2}$ & $116,2 \mathrm{Aa}$ & $114,7 \mathrm{Aa}$ & 115,5 \\
\hline Médias & & 116,4 & 98,3 \\
\hline C.V. \% & 8,13 & & \\
\hline & $S_{1}$ & $177,8 \mathrm{Aa}$ & $138,5 \mathrm{Ab}$ & 158,2
\end{tabular}

IAC-16

\begin{tabular}{ccccc} 
& $S_{2}$ & $147,4 \mathrm{Ba}$ & $133,7 \mathrm{Ab}$ & 140,6 \\
\hline Médias & \multicolumn{5}{c}{162,6} & 136,14 & \\
\hline C.V. \% & & 3,75 & & \\
\hline & $S_{1}$ & $166,9 \mathrm{Aa}$ & $136,4 \mathrm{Bb}$ & 151,7
\end{tabular}

IAC-Foscarin-31

\begin{tabular}{lcccc} 
& $S_{2}$ & 175,2 Aa & 163,3 Aa & 169,3 \\
\hline Médias & \multicolumn{1}{c}{171,1} & 149,9 \\
\hline C.V. \% & 5,38 & & \\
\hline & $S_{1}$ & 190,4 & 169,1 & 179,8 A
\end{tabular}

$B R-4$

\begin{tabular}{lcccc} 
& $S_{2}$ & 180,4 & 174,2 & $177,3 \mathrm{~A}$ \\
\hline Médias & & $185,4 \mathrm{a}$ & $171,7 \mathrm{a}$ & \\
\hline C.V. \% & & 9,88 & & \\
\hline & $S_{1}$ & $180,5 \mathrm{Aa}$ & $153,6 \mathrm{Bb}$ & $\cdots 167,1$
\end{tabular}

IAS-5

\begin{tabular}{lcccc} 
& $\mathrm{S}_{2}$ & $177,6 \mathrm{Aa}$ & $170,1 \mathrm{Aa}$ & 173,9 \\
\hline Médias & 179,1 & 161,9 & \\
\hline C.V. \% & 5,66 & \\
\hline
\end{tabular}

* Para cada cultivar, as médias da mesma coluna seguidas pela mesma letra maiúscula ou da mesma linha seguidas pela mesma letra minúscula não diferiram entre si, ao nível de 5\% de probabilidade, pelo teste de Tukey. 
Isto pode ser explicado pelas temperaturas mais elevadas verificadas em Votuporanga, chegando a $36^{\circ} \mathrm{C}$ (Figura 2), associadas à baixa freqüência de chuvas (Figura 2) coincidindo com o período de enchimento de vagens (R5 a R7), e, ao solo mais arenoso (drenagem rápida), que provocando intensa evapotranspiração da cultura, resultaram em menor disponibilidade hídrica ao desenvolvimento das sementes, embora a irrigação tenha sido realizada neste período.

Por outro lado, segundo comentários de WANG \& WANG (1978), se a luminosidade estiver muito alta e existirem condições favoráveis à transpiração, os estômatos podem se fechar sem que falte umidade no solo; a absoṛção e condução de água tornam-se inferiores à perda pelas folhas, resultando em deficiência hídrica interna que induz murchamento transitório. Acrescentaram que este fenômeno é mais freqüentemente encontrado em soja, em comparação a outras culturas.

A conseqüência do estresse hídrico durante o período de enchimento de vagens é a redução na produção, devido à redução no peso das sementes (SIONIT \& KRAMER, 1977 e RASSINI \& LIN, 1981).

Ainda em $\mathrm{S}_{1}$, apesar de as plantas terem se desenvolvido nitidamente menos em Votuporanga em comparação à Campinas (Tabela 5), as médias de número de vagens por planta (Tabela 8) foram, de modo geral, semelhantes nos 
dois locais, ou até superiores em Votuporanga, para os cultivares IAC-Foscarin-31 e BR-4. Assim, acredita-se na possibilidade de menores quantidades de fotossintetizados terem sido canalizadas para cada semente produzida, resultando na obtenção de sementes mais leves em Votuporanga.

Por outro lado, $\mathrm{S}_{2}$ não houve diferenças significativas entre as médias de peso de mil sementes verificadas nos dois locais para os cultivares estudados, com exceção do IAC-16, que apresentou sementes mais pesadas em Campinas. Verifica-se nesta época, que as temperaturas foram mais amenas nos dois locais por ocasião do período reprodutivo em comparação à $S_{1}$. Embora os valores númericos das médias de altura das plantas tenham sido novamente inferiores em Votuporanga, as médias de número de vagens por planta tambén foram menores neste local, para todos os cultivares, não provocando defasagens quanto ao peso das sementes obtidas nos dois locais.

Comparando-se as duas épocas de semeadura realizadas em Campinas, nota-se que, com exceção do cultivar IAC-16 que apresentou sementes mais pesadas em $\mathrm{S}_{1}$, não houve diferenças significativas quanto ao peso de mil sementes.

Em Votuporanga, as condições climáticas adversas ao desenvolvimento das sementes ocorreram apenas em $S_{1}$; assim sendo, em $S_{2}$ constatou-se acréscimo no peso das sementes dos cultivares em comparação à $\mathrm{S}_{1}$, com exceção do ' IAC-16' e do 'BR-4'. 
Por outro lado, o cultivar IAC-16 foi o único que nitidamente demonstrou queda do peso de 1.000 sementes nos dois locais estudados em $S_{2}$, confirmando os resultados obtidos por NICHOLSON \& SINCLAIR (1973) e NAKAGAWA et al. (1983) e contrariando as informações obtidas por MILANEZ et al. (1978) \& PAYNE et al. (1978). NAKAGAWA et al. (1983) atribuíram este fato ao menor período disponível à produção e translocação de fotossintetizados para a semente, em conseqüência da redução do ciclo cultural, resultando em menor peso das sementes quando se atrasa a semeadura.

Assim, os resultados da presente pesquisa mostraram que o peso de 1.000 sementes de soja pode ser influenciado pela época de semeadura, dependendo do cultivar considerado, e ou das condições climáticas verificadas no período de condução da cultura.

\subsection{Produção de Sementes}

Examinando-se a Tabela 10, nota-se que em $S_{1}$ os cultivares 'IAC-100' e 'IAS-5' apresentaram médias de produção de sementes significativamente superiores em Campinas em comparação à Votuporanga. Considerando-se o cultivar IAC-100, atribui-se a maior produção de sementes em Campinas ao maior peso das sementes (Tabela 9) observado neste local, pois a média do número de vagens por planta (Tabela 8) foi semelhante nos dois locais. 
Tabela 10. Produção de sementes: valores médios ( $\mathrm{kg} / \mathrm{ha})$ obtidos para cada cultivar de soja, em função de épocas e locais de semeadura.

\begin{tabular}{lcccc}
\hline Cultivares & Épocas de Semeadura & Campinas & Votuporanga & Médias \\
\hline IAC-100 & $\mathrm{S}_{1}$ & $2.940,02$ & $2.217,70$ & $2.578,86 \mathrm{~A}$ \\
& $\mathrm{~S}_{2}$ & $2.132,16$ & $1.099,68$ & $1.615,92 \mathrm{~B}$ \\
\hline Médias & & $2.536,09 \mathrm{a}$ & $1.658,69 \mathrm{~b}$ & \\
\hline C.V. \% & & 23,29 & & \\
\hline & $\mathrm{S}_{1}$ & $2.565,44 \mathrm{Aa}$ & $2.484,78 \mathrm{Aa}$ & $2.525,10$
\end{tabular}

IAC-16

\begin{tabular}{|c|c|c|c|c|}
\hline & $\mathrm{S}_{2}$ & $1.915,24 \mathrm{Ba}$ & $1.085,44 \mathrm{Bb}$ & $1.500,34$ \\
\hline Médias & . & $2.240,33$ & $1.785,11$ & \\
\hline C.V. $\%$ & & 26,08 & & \\
\hline & $s_{1}$ & $2.449,52$ & $2.243,54$ & $2.346,53 \mathrm{~A}$ \\
\hline
\end{tabular}

IAC-Foscarin-31

\begin{tabular}{lcccc} 
& $\mathrm{S}_{2}$ & $1.681,28$ & $1.261,78$ & $1.471,50 \mathrm{~B}$ \\
\hline Médias & & $2.065,42 \mathrm{a}$ & $1.752,66 \mathrm{a}$ \\
\hline C.V. \% & 22,16 & \\
\hline & $\mathrm{S}_{1}$ & $2.438,98 \mathrm{Aa}$ & $2.635,06 \mathrm{Aa}$ & $2.537,02$
\end{tabular}

BR-4

\begin{tabular}{lcccc} 
& $S_{2}$ & $2.352,90 \mathrm{Aa}$ & $1.671,24 \mathrm{Bb}$ & $2.012,27$ \\
\hline Médias & \multicolumn{1}{c}{$2.395,94$} & $2.153,15$ & \\
\hline C.V. \% & \multicolumn{1}{c}{13,31} & \\
\hline$S_{1}$ & $2.520,96$ & $2.059,64$ & $2.290,30 \mathrm{~A}$
\end{tabular}

IAS-5

\begin{tabular}{lcccc} 
& $S_{2}$ & $1.984,16$ & $1.397,96$ & $1.691,06 \mathrm{~B}$ \\
\hline Médias & $2.252,55 \mathrm{a}$ & $1.728,80 \mathrm{~b}$ \\
\hline C.V. \% & 18,24 \\
\hline
\end{tabular}

* Para cada cultivar, as médias da mesma coluna seguidas pela mesma letra maiúscula ou da mesma linha seguidas pela mesma letra minúscula não diferiram entre si, ao nível de 5\% de probabilidade, pelo teste de Tukey. 
Os cultivares 'IAC-16', 'IAC-Foscarin-31' e 'BR-4' não apresentaram diferenças significativas quanto às médias de sementes produzidas nos dois locais em $\mathrm{S}_{1}$. Cabe salientar, que em Campinas nesta época, observou-se a ocorrência de sintoma de murcha de plantas em reboleira, atingindo algumas parcelas do experimento com maior intensidade, resultando em secagem prematura de plantas quando se encontravam no estádio R5; através da análise de fitossanidade destas plantas, isolou-se um complexo de fungos: Fusarium spp, Rizoctonia solani e Verticillium spp, além de um nematóide do gênero Helichotylenchus.

Verificou-se, assim, a redução do número inicial de 20 plantas por metro para 14 plantas por metro no cultivar IAC-16, 15 plantas por metro no 'IAC-Foscarin31' e 'BR-4' e 16 plantas por metro no 'IAS-5'. Poucas plantas do cultivar IAC-100 foram afetadas, não interferindo no número médio de plantas por metro, e portanto, não afetando a produtividade.

Considerando-se o cultivar IAC-16, constatase que 0 menor peso de 1.000 sementes (Tabela 9), verificado em Votuporanga, foi compensado pelas menores médias de número de plantas por metro linear obtidas em Campinas, levando a produções semelhantes de sementes nos dois locais.

Quanto aos cultivares 'IAC-Foscarin-31' e 'BR-4', as médias inferiores de peso de mil sementes (Tabela 9), observadas em Votuporanga, foram compensadas 
pelas menores médias de número de plantas por metro linear obtidas em Campinas e pelas médias de número de vagens por planta, significativamente superiores em Votuporanga.

Para o cultivar 'IAS-5', a média do número de vagens por planta (Tabela 8) e a do peso de mil sementes (Tabela 9) superiores em Campinas compensaram a menor média do número de plantas por metro linear observada neste local, resultando na obtenção de maior produção de sementes, em comparação à Votuporanga.

Em $S_{2}$, nota-se que, de modo geral, a produção de sementes foi significativamente superior em Campinas, refletindo principalmente os maiores números de vagens por planta (Tabela 8) produzidos neste local, pois, - peso de mil sementes (Tabela 9) foi significativamente superior em Campinạs em comparação à Votuporanga, apenas para o cultivar 'IAC-16'.

Comparando-se épocas de semeadura, nota-se que $\mathrm{S}_{1}$ proporcionou melhores resultados quanto à produtividade da cultura nos dois locais estudados em comparação à semeadura efetuada em $\mathrm{S}_{2}$, confirmando as informações contidas na literatura (EEASTER, 1949; ABEL, 1961; NICHOLSON \& SINCLAIR, 1973; NAKAGAWA et al., 1983 e JOHNSON, 1987) •

A redução da produção de sementes em $S_{2}$ foi conseqüência dos menores números de vagens por planta (Tabela 8), obtidos nesta época; além disso, para o cultivar IAC-16, principalmente em Campinas, esta redução 
deveu-se também ao menor peso de 1000 sementes (Tabela 9). Em Votuporanga, os maiores pesos de 1.000 sementes verificados em $S_{2}$ para todos os cultivares, exceto o 'IAC16', não foram suficientes para compensar os números de vagens por planta, acentuadamente reduzidos nesta época em comparação à $S_{1}$.

Os resultados obtidos nesta pesquisa confirmaram que a redução na produção de sementes, em conseqüência do atraso na época de semeadura, está mais associada ao menor número de sementes produzidas do que ao decréscimento no tamanho e, conseqüentemente, no peso das sementes (DIMMOCK \& WARREN, 1953; NAKAGAWA et al., 1983 e BOARD, 1987).

\subsection{Qualidade Fisiológica das Sementes}

A Tabela 11 contém os dados médios referentes ao grau de umidade das sementes. Embora estes não tenham sido analisados estatisticamente, nota-se que não ocorreram diferenças consideráveis entre os locais para as sementes produzidas em $S_{1}$ ou $S_{2}$, quando a determinação do grau de umidade foi efetuada após a colheita (E1).

Comparando-se épocas de semeadura, constatase superioridade do grau de umidade das sementes obtidas em $\mathrm{S}_{1}$ em relação às produzidas em $\mathrm{S}_{2}$ nos dois locais estudados. Isto se deve ao fato de os testes direcionados à avaliação da qualidade das sementes, após a colheita, terem sido conduzidos no mês de maio de 1990 para as sementes obtidas em $S_{1}$ e no mês de agosto de 1990 para as sementes produzidas em $\mathrm{S}_{2}$. 
Tabela 11. Grau de umidade: Valores médios (\%) obtidos para cada cultivar de soja, após a colheita das sementes e durante o mês de novembro, em função de épocas e locais de semeadura.

\begin{tabular}{|c|c|c|c|c|c|c|c|}
\hline \multirow[t]{2}{*}{ Cultivares } & \multirow{2}{*}{$\begin{array}{l}\text { Épocas de } \\
\text { semeadura }\end{array}$} & \multicolumn{3}{|c|}{ Após colheita (E1) } & \multicolumn{3}{|c|}{ Novembro 1990 (E2) } \\
\hline & & Campinas & Votuporanga & Médias & Campinas & Votuporanga & Médias \\
\hline & $s_{1}$ & 12,2 & 11,2 & 11,7 & 9,9 & 9,3 & 9,6 \\
\hline \multirow[t]{2}{*}{ IAC-100 } & & & .. & & & & \\
\hline & $\mathbf{S}_{2}$ & 9,1 & 8,6 & 8,9 & 10,2 & 10,0 & 10,1 \\
\hline \multirow[t]{2}{*}{ Médias } & & 10,7 & 9,9 & & 10,1 & 9,7 & \\
\hline & s, & 11,9 & 11,4 & 11,7 & 9,7 & 9,1 & 9,4 \\
\hline
\end{tabular}

IAC-16

\begin{tabular}{cccccccc} 
& $S_{2}$ & 9,2 & 9,0 & 9,1 & 10,3 & 9,7 & 10,0 \\
\hline Módias & & 10,6 & 10,2 & & 10,0 & 9,4 & \\
\hline & $s_{1}$ & 11,3 & 10,9 & 11,1 & 9,6 & 9,1 & 9,4
\end{tabular}

IAC-Foscarin-31

\begin{tabular}{lccccccc} 
& $S_{2}$ & 9,4 & 8,9 & 9,2 & 10,3 & 9,8 & 10,1 \\
\hline Médias & & 10,4 & 9,9 & & 10,0 & 9,5 & \\
\hline & $S_{1}$ & 11,3 & 11,4 & 11,3 & 9,9 & 9,0 & 9,5
\end{tabular}

BR-4

\begin{tabular}{llllllll} 
& $S_{2}$ & 9,7 & 8,9 & 9,3 & 10,3 & 9,7 & 10,0 \\
\hline Médias & & 10,5 & 10,2 & & 10,1 & 9,4 & \\
\hline & $S_{1}$ & 11,6 & 11,0 & 11,3 & 9,6 & 8,9 & 9,3
\end{tabular}

IAS-5

\begin{tabular}{lllllll}
$S_{2}$ & 9,4 & 8,8 & 9,1 & 10,3 & 9,7 & 10,0 \\
\hline 10,5 & 9,9 & & 10,0 & 9,3 \\
\hline
\end{tabular}


Analisando-se a Figura 6, verifica-se que a umidade relativa do ar em Campinas, onde foram armazenadas as sementes, foi mais elevada no mês de maio em comparação ao mês de agosto. Assim, as sementes obtidas em $\mathrm{S}_{1}$, em equilíbrio com umidade relativa do ambiente mais elevada, também apresentaram graus de umidade superiores aos das sementes produzidas em $\mathrm{S}_{2}$.

Na época em que seria plantada a safra seguinte de soja (E2), a avaliação da qualidade das sementes produzidas nos dois locais nas duas épocas de semeadura foi conduzida na mesma ocasião, novembro de 1990; por isso, não se observaram diferenças relevantes entre as médias de grau de umidade das sementes.

As Tabelas 12 e 13 contém os níveis de significância relativos aos valores de $F$ obtidos nas análises de variância, referentes aos parâmetros de qualidade fisiológica das sementes de soja avaliados em E1 e E2, respectivamente.

Observando-se as Figuras 1 e 2, verifica-se que o período reprodutivo da cultura da soja coincidiu com temperaturas elevadas e considerável freqüência de chuvas nos dois locais estudados, quando a semeadura foi efetuada em $S_{1}$. Porém, a temperatura manteve-se mais elevada em Votuporanga e o volume de chuvas, principalmente na fase compreendida entre o início do enchimento das sementes (R5) e a colheita (R8) foi superior em Campinas. 
Tabela 12. Níveis de significầncia dos valores de F obtidos nas análises de variância, referentes aos parâmetros de qualidade fisiológica das sementes de soja, avaliados após a colheita (E1).

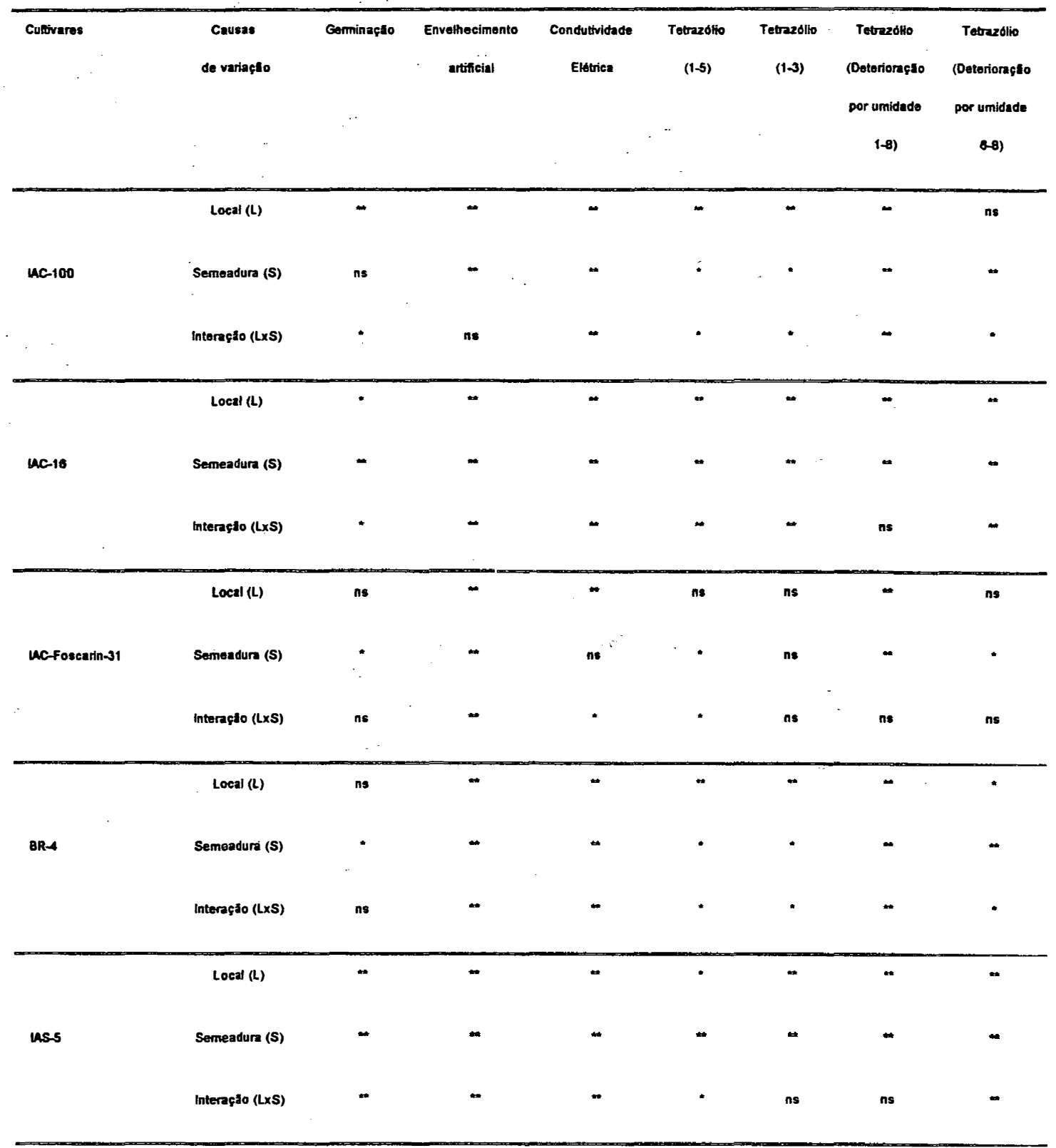

ns não significativo.

* significativo ao nível de 5\% de probabilidade.

** significativo ao nível de 1\% de probabilidade. 
Tabela 13. Níveis de significância dos valores de F obtidos nas análises de variância, referentes aos parâmetros de qualidade fisiológica das sementes de soja, avaliados em novembro de 1990 (E2).

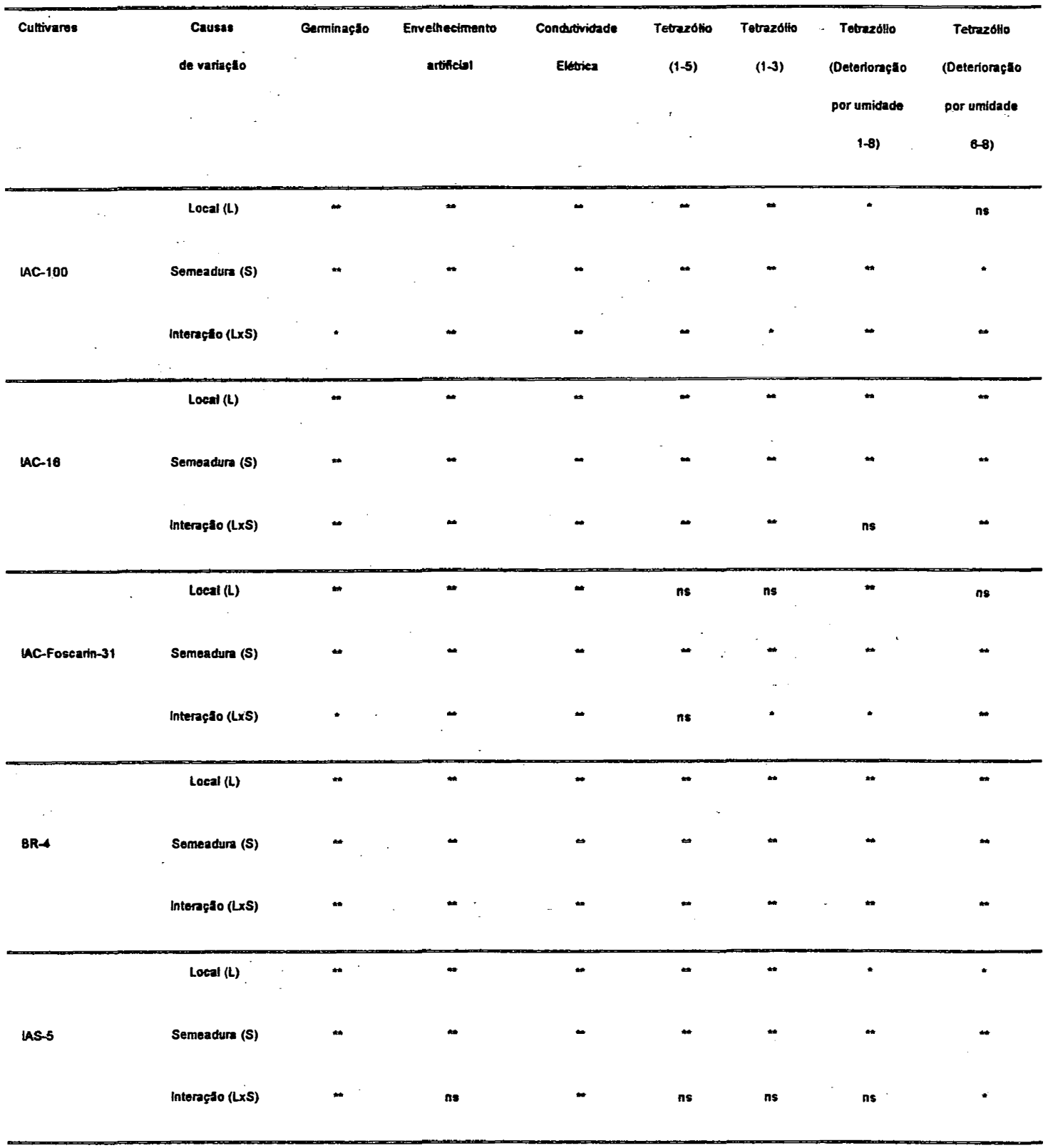

ns não significativo.

* significativo ao nível de 5\% de probabilidade.

** significativo ao nível de $1 \%$ de probabilidade. 
Comparando-se os dois locais em $\mathrm{S}_{1}$, observase que logo após a colheita (E1), as sementes dos cultivares 'IAC-100', 'IAC-16' e 'IAS-5' apresentaram porcentagens de germinação (Tabela 14) significativamente superiores quando obtidas em Campinas, enquanto que as sementes dos cultivares 'IAC-Foscarin-31' e 'BR-4', produzidas nos dois locais, mostraram porcentagens de germinação semelhantes.

A superioridade das sementes produzidas em Campinas em comparação à Votuporanga em $S_{1}$ foi melhor evidenciada para todos os cultivares através do teste de envelhecimento artificial (Tabela 15), mais sensivel para comparar potenciais fisiológicos do que o teste de germinação.

Os testes de condutividade elétrica (Tabela 16) e de Tetrazólio 1-3 (Tabela 18) também confirmaram a melhor qualidade fisiológica das sementes produzidas em Campinas nesta época.

O teste de Tetrazólio 1-5 (Tabela 17) só não acusou viabilidade significativamente maior das sementes produzidas em Campinas em $S_{1}$ para o cultivar IAC-Foscarin31. 
Tabela 14. Germinação: valores médios (\%) obtidos após a colheita das sementes e durante 0 . mês de novembro para cada cultivar de soja, em função de épocas e locais de semeadura.

\begin{tabular}{|c|c|c|c|c|c|c|c|}
\hline \multirow[t]{2}{*}{ Cultivares } & \multirow{2}{*}{$\begin{array}{c}\text { Épocas } \\
\text { de semeadura }\end{array}$} & \multicolumn{3}{|c|}{ Apts colheita (E1) } & \multicolumn{3}{|c|}{ Novembro 1980 (E2) } \\
\hline & & Campinas & Votuporanga & Médias & Campinas & Votuporanga & Médias \\
\hline & $\mathbf{S}_{\mathbf{1}}$ & $97 \mathrm{Aa}$ & $82 \mathrm{Ab}$ & 90 & $92 \mathrm{Aa}$ & $64 \mathrm{Bb}$ & 78 \\
\hline \multirow[t]{2}{*}{ IAC-100 } & & & & - & & & \\
\hline & $S_{2}$ & $80 \mathrm{Ba}$ & - $87 \mathrm{Aa}$ & 89 & $84 \mathrm{Aa}$ & $87 \mathrm{Aa}$ & 91 \\
\hline Médias & & 94 & 85 & & 93 & 76 & \\
\hline \multirow[t]{2}{*}{ C.V\% } & & & 7,29 & & 8,97 & & \\
\hline & $\mathbf{S}_{1}$ & $87 \mathrm{Aa}$ & $68 \mathrm{Bb}$ & 78 & $90 \mathrm{Aa}$ & $48 \mathrm{Bb}$ & 69 \\
\hline
\end{tabular}

IAC-16

\begin{tabular}{|c|c|c|c|c|c|c|c|}
\hline & $\mathbf{s}_{2}$ & $94 \mathrm{Aa}$ & $94 \mathrm{Aa}$ & 94 & $95 \mathrm{Aa}$ & $95 \mathrm{Aa}$ & 95 \\
\hline Médias & & 91 & 81 & & 93 & 72 & \\
\hline c.V. $\%$ & & & 8,49 & & 7,40 & & \\
\hline & $\mathbf{S}_{1}$ & 87 & 87 & $87 \mathrm{~B}$ & $87 \mathrm{Ba}$ & $\pi B b$ & 82 \\
\hline
\end{tabular}

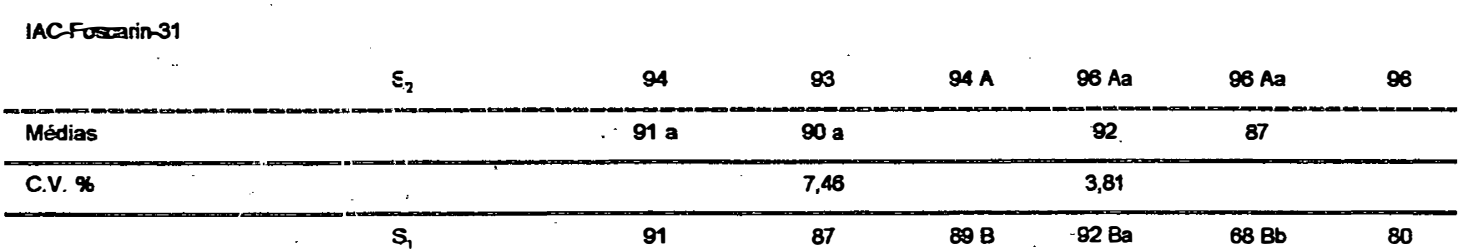

BR-4

\begin{tabular}{|c|c|c|c|c|c|c|c|}
\hline & $\mathbf{S}_{2}$ & 86 & 93 & $95 \mathrm{~A}$ & $97 \mathrm{Aa}$ & $95 \mathrm{Aa}$ & 96 \\
\hline Médias & & $94 a$ & 90 a & 95 & 82 & & \\
\hline C.V \% & & & 6,80 & & 5,13 & & \\
\hline & $s_{1}$ & $93 \mathrm{Aa}$ & $80 \mathrm{Bb}$ & 87 & $84 \mathrm{Ba}$ & $58 \mathrm{Bb}$ & 70 \\
\hline
\end{tabular}

IAS 5

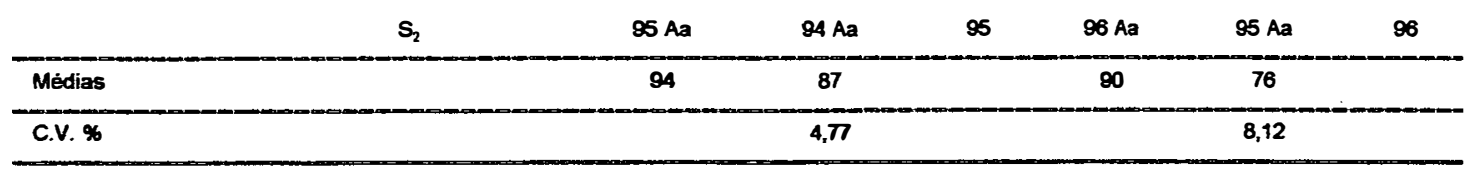

* Para cada cultivar e época de testes, as médias da mesma coluna seguidas pela mesma letra maiúscula ou da mesma linha seguidas pela mesma letra minúscula não diferiram entre si, ao nível de 5\% de probabilidade, pelo teste de Tukey • 
Tabela 15. Envelhecimento artificial: valores médios $\left(\frac{\circ}{\circ}\right)$ obtidos após a colheita das sementes e durante - mês de novembro, para cada cultivar de soja, em função de épocas e locais de semeadura.

\begin{tabular}{|c|c|c|c|c|c|c|c|}
\hline \multirow{2}{*}{ Cultivares } & \multirow{2}{*}{$\begin{array}{l}\text { Épocas de } \\
\text { Semeadura }\end{array}$} & \multicolumn{3}{|c|}{ Após Colheita (E1) } & \multicolumn{3}{|c|}{ Noventro de 1990 (E2) } \\
\hline & & Campinas & Votuporanga & Médias & Campinas & Votuporanga & Médias \\
\hline & s, & 80 & 68 & $79 \mathrm{~b}$ & $88 \mathrm{Ba}$ & $34 \mathrm{Bb}$ & 60 \\
\hline \multicolumn{8}{|l|}{ IAC-100 } \\
\hline & $s_{2}$ & 96 & 88 & $92 \mathrm{~A}$ & $95 \mathrm{Aa}$ & $95 \mathrm{Al}$ & 85 \\
\hline Médias & & $93 a$ & $78 \mathrm{~b}$ & & 91 & 65 & \\
\hline C.V. $\%$ & & & 6,86 & & & $-9,41$ & \\
\hline & $s_{1}$ & $91 \mathrm{Aa}$ & $53 \mathrm{Bb}$ & 72 & $86 \mathrm{Bb}$ & $30 \mathrm{Bb}$ & 58 \\
\hline & $s_{2}$ & $92 \mathrm{Aa}$ & $84 \mathrm{Aa}$. & 88 & $95 \mathrm{Aa}$ & $92 \mathrm{Aa}$ & 94 \\
\hline Médias & & 92 & 69 & & 91 & 61 & \\
\hline c.v. $\%$ & & & 8,54 & & & 10,34 & \\
\hline & $\mathbf{s}_{1}$ & $92 \mathrm{Aa}$ & $75 \mathrm{Bb}$ & 84 & $87 \mathrm{Ba}$ & $37 \mathrm{Bb}$ & 62 \\
\hline
\end{tabular}

IAC-FOSCARIN-31

\begin{tabular}{|c|c|c|c|c|c|c|c|}
\hline & $s_{2}$ & $93 \mathrm{Aa}$ & $93 \mathrm{Aa}$ & 93 & $85 \mathrm{Aa}$ & $96 \mathrm{Aa}$ & 98 \\
\hline Módias & & 93 & 84 & & 91 & 67 & \\
\hline C.V.\% & & & 3,28 & & & 6,16 & \\
\hline & $\mathbf{s}_{1}$ & $88 \mathrm{Ba}$ & $62 \mathrm{Bb}$ & 75 & $84 \mathrm{Ba}$ & $28 \mathrm{Bb}$ & 55 \\
\hline
\end{tabular}

BR-4

\begin{tabular}{|c|c|c|c|c|c|c|c|}
\hline & $s_{2}$ & $94 \mathrm{Aa}$ & $93 \mathrm{Aa}$ & 94 & $96 \mathrm{Aa}$ & $95 \mathrm{Aa}$ & 96 \\
\hline Médias & & 91 & 78 & & 80 & 61 & \\
\hline C.V. $\%$ & & & 5,93 & & & 5,67 & \\
\hline
\end{tabular}

IASS

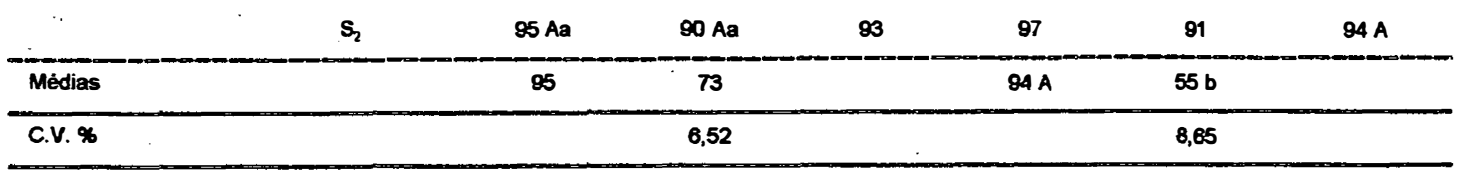

* Para cada cultivar e época de testes, as médias da mesma coluna seguidas pela mesma letra maiúscula ou da mesma linha seguidas pela mesma letra minúscula não diferiram entre si, ao nível de 5\% de probabilidade, pelo Teste de Tukey • 
Tabela 16. Condutividade elétrica: valores médios $(\mu \mathrm{mhos} / \mathrm{cm} / \mathrm{g})$ obtidos após a colheita das sementes e durante 0 mês de novembro para cada cultivar de soja, em função de épocas e locais de semeadura.

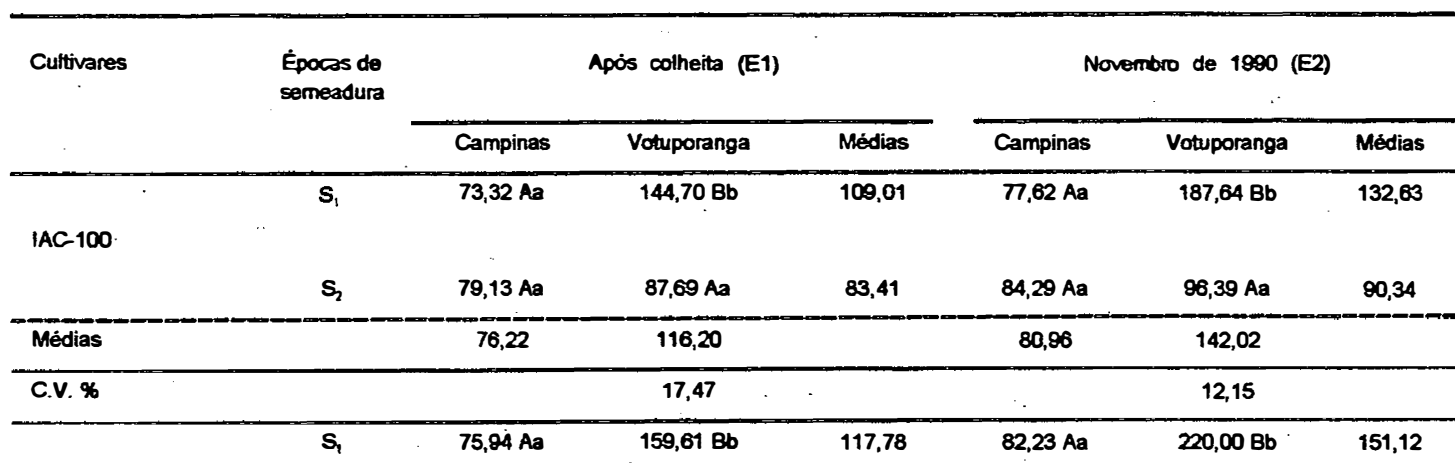

IAC-16

\begin{tabular}{lccccccc} 
& $S_{2}$ & $71,02 \mathrm{Aa}$ & $88,80 \mathrm{Aa}$ & 79,92 & $67,13 \mathrm{Aa}$ & $105,59 \mathrm{Ab}$ & 86,38 \\
\hline Médias & & 73,48 & 124,21 & 74,68 & 162,80 \\
\hline C.V. \% & & \multicolumn{1}{c}{15,59} & & 16,64 & \\
\hline & $S_{1}$ & $74,28 \mathrm{Aa}$ & $103,29 \mathrm{Bb}$ & 88,79 & $84,55 \mathrm{Aa}$ & $147,58 \mathrm{Bb}$ & 116,07
\end{tabular}

IACFosorin-31

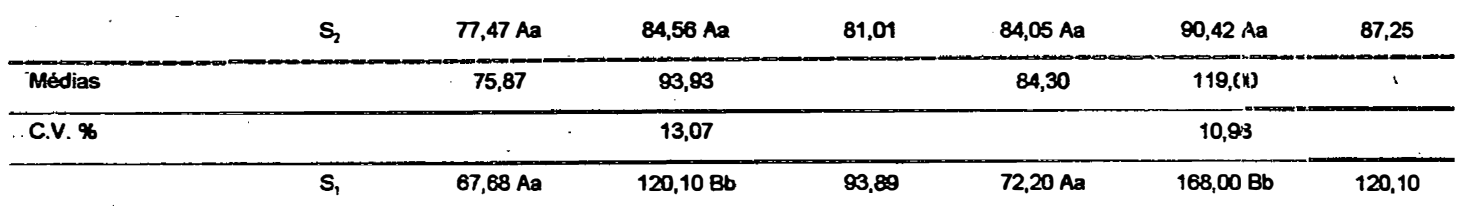

BR-4

\begin{tabular}{|c|c|c|c|c|c|c|c|}
\hline & $S_{2}$ & $60,06 \mathrm{Aa}$ & $70,80 \mathrm{Aa}$ & 65,43 & $65,31 \mathrm{Aa}$ & $77,59 \mathrm{Aa}$ & 71,45 \\
\hline Médias & . & 63,87 & 95,45 & & 68,76 & 122,80 & \\
\hline C.V. $\%$ & & & 11,99 & & 14,17 & & \\
\hline & s, & $69,72 \mathrm{Aa}$ & $146,38 \mathrm{Bb}$ & 108,05 & $73,74 \mathrm{Aa}$ & $191,11 \mathrm{Bb}$ & 132,42 \\
\hline
\end{tabular}

IAS-5

\begin{tabular}{lccccccc} 
& $S_{2}$ & $67,39 \mathrm{Aa}$ & $83,51 \mathrm{Ab}$ & 75,45 & $72,01 \mathrm{Aa}$ & $94,39 \mathrm{Aa}$ & 83,20 \\
\hline Médias & 68,55 & 114,94 & & 72,87 & 142,75 \\
\hline C.V. \% & 11,39 & 19,35 \\
\hline
\end{tabular}

* Para cada cultivar e época de testes, as médias da mesma coluna seguidas pela mesma letra maiúscula ou da mesma linha seguidas pela mesma letra minúscula não diferiram entre si, ao nível de 5\% de probabilidade, pelo teste de Tukey. 
Tabela 17. Teste de Tetrazólio 1-5 (viabilidade): valores médios (\%) obtidos após a colheita das sementes e durante o mês de novembro pará cada cultivar de soja, em função de épocas e locais de semeadura.

\begin{tabular}{|c|c|c|c|c|c|c|c|}
\hline \multirow[t]{2}{*}{ Cultivares } & \multirow{2}{*}{$\begin{array}{l}\text { Épocas de } \\
\text { semeadura }\end{array}$} & \multicolumn{3}{|c|}{ Após collheita (E1) } & \multicolumn{3}{|c|}{ Noverbro de 1990 (E2) } \\
\hline & & Campinas & Votuporanga & Médias & Campinas & Votuporanga & Médias \\
\hline \multirow{3}{*}{ IAC-100 } & $s_{1}$ & $97 \mathrm{Aa}$ & $85 \mathrm{Bb}$ & 91 & $92 \mathrm{Aa}$ & $70 \mathrm{Bb}$ & 81 \\
\hline & & & . & & & - & \\
\hline & $s_{2}$ & $98 \mathrm{Aa}$ & $96 \mathrm{Aa}$ & 97 & $95 \mathrm{Aa}$ & $94 \mathrm{Aa}$ & 95 \\
\hline Médias & & 98 & 91 & & 94 & 82 & \\
\hline C.V. \% & & 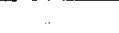 & 6,10 & & & 7,77 & \\
\hline & $s_{1}$ & $94 \mathrm{Aa}$ & $75 \mathrm{Bb}$ & 85 & $92 \mathrm{Aa}$ & $63 \mathrm{Bb}$ & 78 \\
\hline
\end{tabular}

IAC-16

\begin{tabular}{lccccccc} 
& $S_{2}$ & $96 \mathrm{Aa}$ & $95 \mathrm{Aa}$ & 96 & $93 \mathrm{Aa}$ & $91 \mathrm{Aa}$ & 92 \\
\hline Médias & & 85 & 85 & 93 & 77 \\
\hline C.V. \% & & 6,72 & & 9,61 \\
\hline & $S_{1}$ & $93 \mathrm{Aa}$ & $89 \mathrm{Ba}$ & 91 & 82 & 73 & $78 \mathrm{~B}$
\end{tabular}

IACFosarin-31

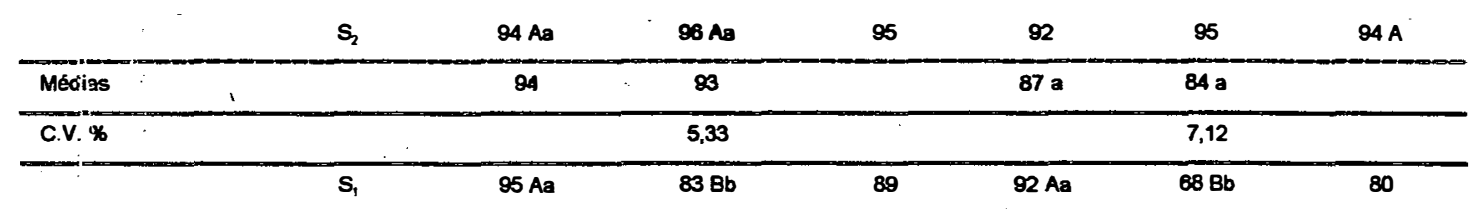

BR-4

\begin{tabular}{|c|c|c|c|c|c|c|c|}
\hline & $S_{2}$ & $96 \mathrm{Aa}$ & $92 \mathrm{Aa}$ & 94 & $95 \mathrm{Aa}$ & $94 \mathrm{Aa}$ & 95 \\
\hline Módias & & 96 & 88 & & 94 & 81 & \\
\hline C.V. $\%$ & & & 6,69 & & & 6,38 & \\
\hline
\end{tabular}

IAS-5

\begin{tabular}{|c|c|c|c|c|c|c|}
\hline & 96 Aa & $92 \mathrm{Aa}$ & 94 & 98 & 94 & $96 \mathrm{~A}$ \\
\hline Módias & 95 & 88 & & 80 a & $79 \mathrm{~b}$ & \\
\hline C.V. \% & & 6,11 & & & 6.29 & \\
\hline
\end{tabular}

* Para cada cultivar e época de testes, as médias da mesma coluna seguidas pela mesma letra maiúscula ou da mesma linha seguidas pela mesma letra minúscula não diferiram entre si, ao nível de 5\% de probabilidade, pelo teste de Tukey. 
Tabela 18. Teste de Tetrazólio 1-3 (vigor): valores médios (\%) obtidos após a colheita das sementes e durante o mês de novembro para cada cultivar de soja, em função de épocas e locais de semeadura.

\begin{tabular}{|c|c|c|c|c|c|c|c|}
\hline \multirow{2}{*}{ Cultivares } & \multirow{2}{*}{$\begin{array}{c}\text { Épocas de } \\
\text { semeadura } \\
\end{array}$} & \multicolumn{3}{|c|}{ Após colheita (E1) } & \multicolumn{3}{|c|}{ Novembro de 1990 (E2) } \\
\hline & & Campinas & Votuporanga & Médias & Campinas & Votuporanga & Médias \\
\hline & $s_{1}$ & $85 \mathrm{Aa}$ & $81 \mathrm{Bb}$ & 88 & $89 \mathrm{Aa}$ & $58 \mathrm{Bb}$ & 74 \\
\hline \multicolumn{8}{|l|}{ IAC-100 } \\
\hline & $s_{2}$ & $95 \mathrm{Aa}$ & $93 \mathrm{Aa}$ & 94 & $92 \mathrm{Aa}$ & $90 \mathrm{Aa}$ & 91 \\
\hline Médias & & 85 & 87 & & 91 & 74 & \\
\hline C.V. $\%$ & & & 5,85 & & & 9,67 & \\
\hline & $s_{1}$ & $80 \mathrm{Aa}$ & $58 \mathrm{Bb}$ & 74 & $88 \mathrm{Aa}$ & $48 \mathrm{Bb}$ & 68 \\
\hline
\end{tabular}

\begin{tabular}{|c|c|c|c|c|c|c|c|}
\hline \multicolumn{8}{|l|}{ IAC-16 } \\
\hline & $s_{2}$ & $92 \mathrm{AD}$ & B8 Aa & 80 & $90 \mathrm{Aa}$ & $79 A b$ & 85 \\
\hline \multicolumn{2}{|l|}{ Médias } & 91 & 73 & & 89 & 64 & \\
\hline \multirow[t]{2}{*}{ C.V. $\%$} & & & 5,84 & & & 6,39 & \\
\hline & $s_{1}$ & $92 \wedge$ & $81 \mathrm{Bb}$ & 87 & $77 \mathrm{Ba}$ & $62 \mathrm{Bb}$ & 70 \\
\hline \multicolumn{8}{|c|}{ |AC-Foscarin-31 } \\
\hline & $s_{2}$ & BB AD & $90 \mathrm{Aa}$ & $\infty$ & $89 \mathrm{Aa}$ & $89 \mathrm{Aa}$ & 89 \\
\hline Módias & & .90 & 88 & & 83 & 76 & \\
\hline \multirow[t]{2}{*}{ C.V. \% } & & & 6,39 & & & 8,22 & \\
\hline & $s_{1}$ & $22 \mathrm{Ag}$ & $72 \mathrm{Bb}$ & 82 & $89 \mathrm{Aa}$ & $54 \mathrm{Bb}$ & 72 \\
\hline \multirow[t]{2}{*}{$B R-4$} & & & & & & & \\
\hline & $s_{2}$ & $85 \mathrm{Aa}$ & $86 \mathrm{Ab}$ & 91 & $93 \mathrm{Aa}$ & $88 \mathrm{Aa}$ & 91 \\
\hline \multicolumn{2}{|l|}{ Médias } & 94 & 79 & & 91 & 71 & \\
\hline \multicolumn{2}{|l|}{ C.V. $\%$} & & 8,45 & & & 8,50 & \\
\hline & $s_{1}$ & 88 & 76 & $82 \mathrm{~B}$ & $\pi$ & 52 & $65 \mathrm{~B}$ \\
\hline \multicolumn{8}{|l|}{ IAS-5 } \\
\hline & $s_{2}$ & 83 & 87 & $90 \mathrm{~A}$ & 85 & 69 & $92 \mathrm{~A}$ \\
\hline Médias & & $91 \mathrm{a}$ & $82 \mathrm{~b}$ & & $86 a$ & $71 \mathrm{~b}$ & \\
\hline C.V. $\%$ & & & 6,54 & & & 6,39 & \\
\hline
\end{tabular}

* Para cada cultivar e época de testes, as médias da mesma coluna seguidas pela mesma letra maiúscula ou da mesma linha seguidas pela mesma letra minúscula não diferiram entre si, ao nível de 5\% de probabilidade, pelo teste de Tukey • 
Observando-se as Tabelas 14 e 17, nota-se que para o cultivar IAC-16 nos dois locais e 'IAC-Foscarin31' e 'BR-4' em Campinas, os valores numéricos obtidos pará o teste de tetrazólio 1-5 foram maiores do que os obtidos para o teste de germinação. Segundo HENNING \& FRANÇA NETO (1980) e FRANÇA NETO et al. (1986), a incidência de microrganismos durante a germinação, principalmente de Phomopsis sojae, pode ter sido responsável pelas diferenças entre as médias obtidas para os dois testes.

Embora a sanidade das sementes tenha sido incluída adiante, vale esclarecer que 0 fungo Phomopsis sojae (Figura 7) ocorreu em nível mais elevado, justamente nas situações onde os valores numéricos das médias do teste de tetrazólio 1-5 foram maiores que os de germinação.

Segundo MARCOS FILHO (1979), a semente de soja é bastante sensível a fatores do ambiente devido às suas características morfológicas e químicas. Umidade relativa do ar e temperaturas elevadas durante o período de maturação aumentam acentuadamente a atividade fisiológica das sementes, predispondo-as ao ataque de patógenos, resultando na redução da germinação e do vigor (CAVINESS, 1978 e COSTA et al., 1987a).

$\mathrm{Na}$ presente pesquisa, constatou-se que as sementes, de modo geral, desenvolveram-se menos nas condições de Votuporanga observadas em $S_{1}$ (Tabela 9), o que pode ter sido consequência de relativa falta de água associada a temperaturas elevadas, na fase de desenvolvimento das sementes. 
Este fator, de acordo com RASSINI \& LIN (1981), também pode resultar em perda de vigor. Observandose a Tabela 19, verifica-se ainda que as maiores porcentagens de sementes apresentando sintomas de deterioração, causados por temperatura e umidade elevadas nas fases finais do ciclo da cultura, foram produzidas em Votuporanga. Esta foi, provavelmente, uma das causas que resultou em médias reduzidas obtidas para os testes de vigor, quando as sementes foram produzidas neste local em $\mathrm{S}_{1}$ em comparação às médias de vigor obtidas para as sementes produzidas em Campinas.

A perda de viabilidade das sementes devido à deterioração causada por temperatura e umidade elevadas (Tabela 20), também explica médias inferiores de germinação e viabilidade (tetrazólio 1-5) das sementes produzidas em Votuporanga em $\mathrm{S}_{1}$.

Sintomas de deterioração observados nos cotilédores das sementes, conforme verificaram TACHIBANA et al. (1968) e FALIVENE et al. (1980), também podem ter resultado das temperaturas mais elevadas ocorridas durante a fase de desenvolvimento das sementes em Votuporanga.

Ainda, o fato de as sementes obtidas em Votuporanga terem apresentado menor tamanho, de acordo com MOORE (1971), as tornaria menos sujeitas à deterioração por alternância de secagem e umedecimento. Entretanto, as condições de chuvas mais espaçadas associadas a temperaturas mais elevadas, encontradas em Votuporanga em $\mathrm{S}_{1}$ (Figura 1 e 2), podem ter levado a processos de secagem e reumedecimento das sementes mais acentuados, resultando em maior obtenção de sementes de soja com tegumentos enrugados e com fissuras em comparação à Campinas. 
Tabela 19. Teste de Tetrazólio 1-8 (sementes com deterioração por "umidade"): valores médios (\%) obtidos após a colheita e durante o mês de novembro para cada cultivar de soja, em função de épocas e locais de semeadura.

\begin{tabular}{|c|c|c|c|c|c|c|c|}
\hline \multirow[t]{2}{*}{ Cultivares } & \multirow{2}{*}{$\begin{array}{l}\text { Épocas de } \\
\text { semeadura }\end{array}$} & \multicolumn{3}{|c|}{ Aposs colheita (E1) } & \multicolumn{3}{|c|}{ Novembro de 1990 (E2) } \\
\hline & & Campinas & Votuporanga & Médias & Campinas & Votuporanga & Médias \\
\hline . & s, & $8 \mathrm{Ab}$ & $34 \mathrm{Aa}$ & 21 & $18 \mathrm{Ab}$ & $52 \mathrm{Aa}$ & 35 \\
\hline \multicolumn{8}{|l|}{$\mid A C-100$} \\
\hline & $\mathrm{S}_{2}$ & $\mathrm{O} \mathrm{Ba}$ & $1 \mathrm{Ba}$ & 1 & $9 \mathrm{Aa}$ & $6 \mathrm{Ba}$ & 8 \\
\hline Médias & & 4 & 18 & & 14 & 29 & \\
\hline C.V. $\%$ & & & 28,37 & & & 34,89 & \\
\hline & $S_{1}$ & 6 & 52 & $29 \mathrm{~A}$ & 16 & 64 & $40 \mathrm{~A}$ \\
\hline
\end{tabular}

IAC-16

\begin{tabular}{|c|c|c|c|c|c|c|c|}
\hline & $S_{2}$ & 0 & 12 & $6 \mathrm{~B}$ & 2 & 19 & $11 \mathrm{~B}$ \\
\hline Médias & & $3 \mathrm{~b}$ & $32 a$ & & $9 \mathrm{~b}$ & $42 a$ & \\
\hline C.V. \% & & & 16,74 & & & 22,10 & \\
\hline & $\mathbf{S}_{1}$ & 5 & 18 & $12 \mathrm{~A}$ & $21 \mathrm{Ab}$ & 45 Aa & 33 \\
\hline
\end{tabular}

IACFoscarin-31

\begin{tabular}{|c|c|c|c|c|c|c|c|}
\hline & $s_{2}$ & 0 & 6 & $3 \mathrm{~B}$ & $6 \mathbf{B a}$ & $9 \mathrm{Ba}$ & 8 \\
\hline Médias & & $3 \mathrm{~b}$ & $12 a$ & & 14 & .27 & ' \\
\hline C.V. \% & & & 27,20 & & & 24,64 & \\
\hline & $S_{1}$ & $12 \mathrm{Ab}$ & $49 \mathrm{Aa}$ & 31 & $18 \mathrm{Ab}$ & $70 \mathrm{Aa}$ & 44 \\
\hline
\end{tabular}

BR-4

\begin{tabular}{|c|c|c|c|c|c|c|c|}
\hline & $S_{2}$ & $1 \mathrm{Ba}$ & $2 \mathrm{Ba}$ & 2. & $8 \mathrm{Ba}$ & 8 Ba & 8 \\
\hline Médias & & 7 & 28 & & 13 & 39 & \\
\hline C.V. \% & & & 24,17 & & & 14,07 & \\
\hline & $S_{1}$ & 9 & 56 & $33 \mathrm{~A}$ & 27 & 76 & $52 \mathrm{~A}$ \\
\hline
\end{tabular}

IAS-5

\begin{tabular}{lcccccc} 
& $S_{2}$ & 0 & 11 & $6 \mathrm{~B}$ & 3 & 17 \\
\hline Médias & $5 \mathrm{~b}$ & $34 \mathrm{a}$ & $15 \mathrm{~b}$ & $47 \mathrm{a}$ \\
\hline C.V. \% & & 14,82 & 12,55 \\
\hline
\end{tabular}

* Para cada cultivar e época de testes, as médias da mesma coluna seguidas pela mesma letra maiúscula ou da mesma linha seguidas pela mesma letra minúscula não diferiram entre si, ao nível de 5\% de probabilidade, pelo teste de Tukey • 
Tabela 20. Teste de tetrazólio 6-8 (perda da viabiliade das sementes devido à deterioração por "umidade"): valores médios (\%) obtidos após a colheita e durante o mês de novembro para cada cultivar de soja, em função de épocas e locais de semeadura.

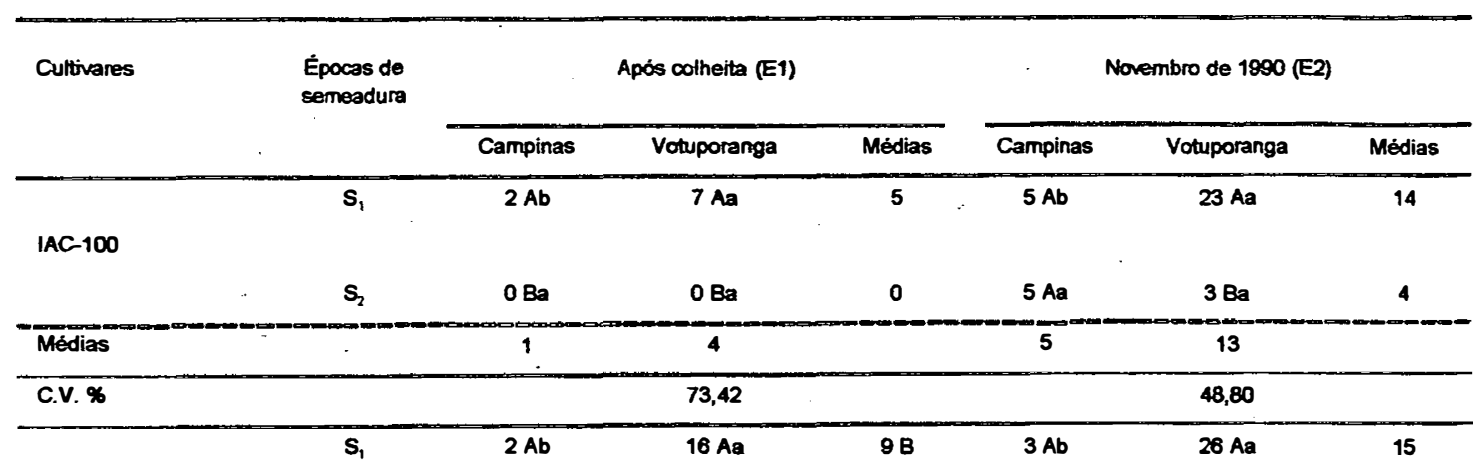

$\operatorname{IAC}-16$

\begin{tabular}{lccccccc} 
& $S_{2}$ & $O B a$ & $1 B a$ & $1 A$ & $1 A a$ & $3 B a$ & 2 \\
\hline Médias & & 1 & 9 & & 2 & 15 & 36,24 \\
\hline C.V. \% & & 32,79 & & & \\
\hline & $S_{i}$ & 3 & 4 & $4 A$ & $9 \mathrm{Ab}$ & $20 \mathrm{Aa}$ & 15
\end{tabular}

ACFoscarin31

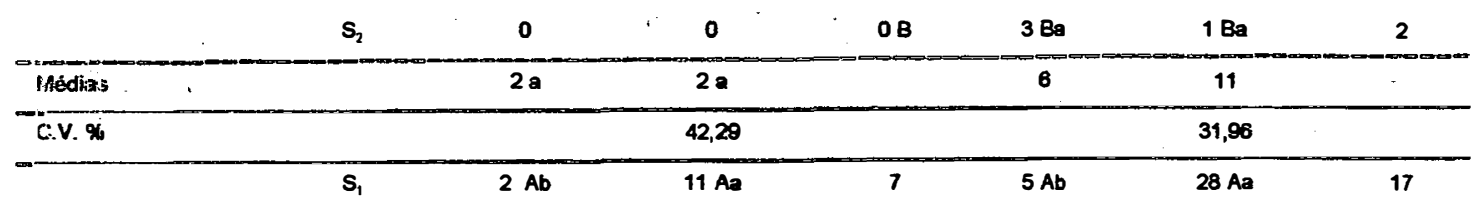

BR-4

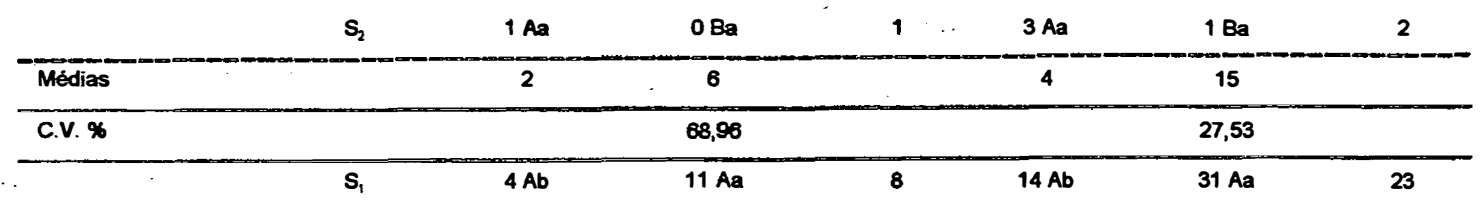

IAS5

\begin{tabular}{lccccccc} 
& $\mathrm{S}_{2}$ & $\mathrm{OBa}$ & $\mathrm{OBa}$ & 0 & $1 \mathrm{Ba}$ & $1 \mathrm{Ba}$ & 1 \\
\hline Médias & 2 & 6 & 8 & 16 & 16 \\
\hline C.V. \% & 34,42 & 32,88 \\
\hline
\end{tabular}

* Para cada cultivar e época de testes, as médias da mesma coluna seguidas pela mesma letra maiúscula ou da mesma linha seguidas pela mesma letra minúscula não diferiram entre si, ao nível de 5\% de probabilidade, pelo Teste de Tukey . 
Por outro lado, analisando-se as Figuras 3 e 4 verifica-se que, principalmente o período que coincidiu com a fase de desenvolvimento de sementes (R5) até a colheita (R8) foi seco e frio em $S_{2}$ em comparação à $S_{1}$, propiciando a obtenção de sementes de excelente qualidade nos dois locais estudados, confirmando a sugestão de ANDREWS (1982), quanto à escolha de regiões com baixa precipitação coincidindo com a maturação para a produção de sementes.

As sementes de todos os cultivares obtidas em $\mathrm{S}_{2}$ não apresentaram diferenças significativas quanto à viabilidade, avaliada após a colheita (E1), através do teste de germinação (Tabela 14) ou do teste de tetrazólio 1-5 (Tabela 17) para ambas as localidades.

Os testes de vigor mostraram diferenças esporádicas de qualidade fisiológica entre as sementes produzidas nos dois locais em $\mathrm{S}_{2}$, de forma que, as sementes do cultivar IAC-100 avaliadas através do teste de envelhecimento artificial (Tabela 15), as sementes do cultivar IAS-5 avaliadas através do teste de condutividade elétrica (Tabela 16) e as sementes dos cultivares 'BR-4' e 'IAS-5' avaliadas através do teste de tetrazólio 1-3 (Tabela 18) apresentaram médias significativamente superiores em Campinas em comparação à Votuporanga. 
Ainda; observando-se a Tabela 19, nota-se que para os cultivares 'IAC-16', 'IAC-Foscarin-31' e 'IAS5' foram obtidas sementes com sintomas de deterioraçào por temperatura e umidade, diagnosticados através do teste de tetrazólio, em nível superior em Votuporanga em comparação à Campinas, provavelmente devido a temperaturas mais elevadas registradas naquele local durante a maturação das sementes. Porém, as lesões observadas nas sementes foram superficiais, não chegando a causar diferenças relevantes quanto à viabilidade das sementes obtidas nos dois locais (Tabela 20) .

Comparando-se as semeaduras conduzidas em Campinas quanto à avaliação da qualidade fisiológica das sementes, realizada após a colheita (i1), constata-se que os testes efetuados não destacaram a superioridade de nenhuma das duas épocas estudadas. As diferenças significativas entre médias obtidas para $S_{1}$ ou $S_{2}$ foram esporádicas, de forma que para o cultivar IAC-100, o teste de germinação (Tabela 14) demonstrou superioridade da média obtida em $S_{1}$, provavelmente, devido à elevada incidência de Phomopsis sojae nas sementes produzidas em $\mathrm{S}_{2}$. Para $\mathrm{O}$ cultivar BR-4, o teste de envelhecimento artificial (Tabela 15) e para o cultivar IAS-5, o teste de tetrazólio 1-3 (Tabela 18) revelaram superioridade das médias obtidas para $\mathrm{S}_{2}$. 
Por outro lado, observando-se a Tabela 19, nota-se nitidamente à obtenção de sementes com sintomas de deterioração por temperatura e umidade, diagnosticados através do teste de tetrazólio, em nível significativemente superior em $S_{1}$ para todos os cultivares, refletindo as condições de clima mais quente e úmido em que foram produzidas as sementes na semeadura convencional (Figura 1) em comparação à semeadura tardia (Figura 3) .

A perda de viabilidade de sementes devido a este fator também foi significativamente superior quando as sementes foram obtidas em $S_{1}$ (Tabela 20), embora os valores numéricos das médias tenham sido baixos nas duas semeaduras.

Comparando-se as duas semeaduras efetuadas em Votuporanga, verifica-se que todos os testes conduzidos em E1 destacaram a superioridade da qualidade fisiológica das sementes produzidas em $S_{2}$. $O$ nível acentuado de sementes com sintomas de deterioração causada por temperatura e umidade elevadas (diagnosticados através do tetrazólio) quando produzidas em $S_{1}$ (Tabelas 19 e 20) demonstrou condições do ambiente não propícias à produção de sementes de soja com qualidade fisiológica satisfatória em $S_{1}$ em Votuporanga (Figura 2), confirmando a dúvida levantada por MARCOS FILHO et al. (1985) quanto à viabilidade de produção de sementes de soja de cultivares precoces em regiões como esta, considerando-se esta época de semeadura. 
As condições de temperatura e umidade relativa do ar observadas durante o armazenamento das sementes em Campinas, desde a colheita até a época em que seria semeada a safra seguinte no Estado de São Paulo $\left(E_{2}\right)$, encontram-se nas Figuras 5 e 6 , respectivamente.

Observando-se estas figuras, verifica-se que as sementes colhidas no final de março em $S_{1}$ permaneceram armazenadas durante período mais prolongado, de aproximadamente 8 meses. Neste período, as sementes foram submetidas a temperaturas e umidades relativas do ar elevadas nos meses de março e abril (fase inicial do armazenamento), e novamente nos meses de setembro a novembro (fase final do armazenamento).

As sementes obtidas no início de julho em $S_{2}$, alérn ce terem sido armazenadas por período mais curto, de aproximadamente 4 meses, foram submetidas a temperaturas e umidades relativas mais elevadas, apenas na fase final do armazenamento, de setembro a novembro.

Considerando-se as sementes produzidas em $S_{1}$, na segunda época de avaliação da qualidade fisiológica das sementes (E2), todos os testes conduzidos demonstraram que as sementes produzidas em Votuporanga apresentaram queda mais acentuada na qualidade para todos os cultivares durante o armazenamento em relação à Campinas, acentuando ainda mais a superioridade das sementes produzidas nesta localidade que havia sido verificada em E1. 
Os níveis de significância relativos aos valores de F, obtidos nas análises de variância dos dados referentes aos testes de emergência de plântulas no campo, encontram-se na Tabela 21.

Observando-se a Tabela 22, constata-se que os três testes de emergência de plântulás conduzidos no campo, na época recomendada para plantio de soja no Estado de São Paulo, confirmaram a qualidade insatisfatória das sementes, de praticamente todos os cultivares, produzidas em Votuporanga e a superioridade das sementes obtidas em Campinas em $\mathrm{S}_{1}$.

Considerando-se em $\mathrm{S}_{2}$, verifica-se que as sementes de todos os cultivares mantiveram elevada qualidade fisiológica no período de armazenamento, conforme revelaram todos os testes conduzidos em E2; as diferenças obtidas entre os dois locais estudados foram esporádicas. Surpreendentemente, os valores numéricos das médias de germinação (Tabela 14) das sementes obtidas em $\mathrm{S}_{2}$ nos dois locais, de modo geral, foram superiores após o armazenamento (E2), provavelmente, devido à redução do nível de patógenos de campo incidentes nas sementes por ocasião da colheita. Os testes de emergência de plântulas em campo, também realizados nesta época (Tabela 22), confirmaram a elevada qualidade das sementes produzidas em $\mathrm{S}_{2}$ nos dois locais. 
Tabela 21. Níveis de significância dos valores de F obtidos nas análises de variância dos dados referentes aos testes de emergência de plântulas no campo.

\begin{tabular}{|c|c|c|c|c|}
\hline \multirow[t]{2}{*}{ Cultivares } & \multirow{2}{*}{$\begin{array}{l}\text { Causas de } \\
\text { Variação }\end{array}$} & \multicolumn{3}{|c|}{ VALORES DE F } \\
\hline & & TESTE 1 & TESTE 2 & TESTE 3 \\
\hline \multirow{3}{*}{$\mid A C-100$} & Local (L) & * & * & $\Rightarrow$ \\
\hline & Semeadura (S) & * & $\star *$ & $* *$ \\
\hline & Interação (LXS) & ** & * & $* *$ \\
\hline \multirow{3}{*}{ IAC-16 } & Local (L) & ** & $*$ & $* *$ \\
\hline & Semeadura (S) & $\#$ & $\#$ & $* *$ \\
\hline & Interaçăo (LXS) & $\star *$ & $* *$ & $*$ \\
\hline \multirow{3}{*}{ IAC-Foscarin-31 } & Local (L) & * & 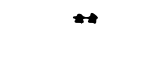 & $*$ \\
\hline & Semeadura (S) & ns & $*$ & $*$ \\
\hline & Interação (LXS) & * & $*$ & $\star$ \\
\hline \multirow{3}{*}{$B R-4$} & Local (L) & $*$ & $*$ & $*$ \\
\hline & Semeadura (S) & $*$ & 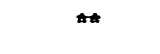 & $*$ \\
\hline & Interação (LXS) & $\star$ & $*$ & ns \\
\hline \multirow{3}{*}{ IAS-5 } & Local (L) & $*$ & $*$ & $*$ \\
\hline & Semeadura (S) & $\star *$ & $\#$ & $*$. \\
\hline & Interação (LXS) & $*$ & $*$ & $\#$ \\
\hline
\end{tabular}

ns não significativo.

* significativo ao nível de 5\% de probabilidade.

** significativo ao nível de $1 \%$ de probabilidade. 
Tabela 22. Emergência de plântulas no campo: valores médios (\%) obtidos no período de novembro a dezembro de 1990, para cada cultivar de soja, em função de épocas e locais de semeadura.

\begin{tabular}{|c|c|c|c|c|c|c|c|c|c|c|}
\hline \multirow{2}{*}{ Cultivares } & \multirow{2}{*}{$\begin{array}{l}\text { Época de } \\
\text { Serneadura }\end{array}$} & \multicolumn{3}{|c|}{ Teste 1} & \multicolumn{3}{|c|}{ Teste 2} & \multicolumn{3}{|c|}{ Teste 3} \\
\hline & & Campinas & Votuporanga & Médias & Campinas & Votuporanga & Médias & Campinas & Votuporanga & Médias \\
\hline & $\mathbf{S}_{i}$ & $90 \mathrm{Aa}$ & $73 \mathrm{Bb}$ & 82 & $88 \mathrm{Aa}$ & $62 \mathrm{Bb}$ & 75 & $92 \mathrm{Aa}$ & $64 \mathrm{Bb}$ & 78 \\
\hline
\end{tabular}

IAC-100

\begin{tabular}{|c|c|c|c|c|c|c|c|c|c|c|}
\hline & $S_{2}$ & $92 \mathrm{Aa}$ & S4 Aa & 93 & $94 \mathrm{Aa}$ & $93 \mathrm{Aa}$ & 94 & $94 \mathrm{Aa}$ & 94Aa & 94 \\
\hline Médias & & 91 & 84 & & 91 & 78 & & 93 & 79 & \\
\hline C.V. \% & & & 6,32 & & & 10,15 & & & 9,04 & \\
\hline & $s_{1}$ & 86 Aa & $52 \mathrm{Bb}$ & 69 & $89 \mathrm{Aa}$ & $418 b$ & 65 & $88 \mathrm{Ba}$ & $49 \mathrm{Bb}$ & 69 \\
\hline
\end{tabular}

IAC-16

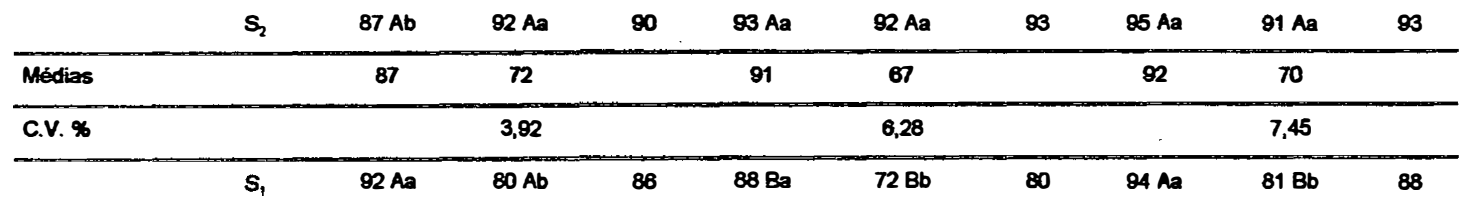

IACFoscarin-31

\begin{tabular}{|c|c|c|c|c|c|c|c|c|c|c|}
\hline & $S_{2}$ & $88 \mathrm{Aa}$ & $85 \mathrm{Aa}$ & 86 & O4 Aa & $94 \mathrm{Aa}$ & 94 & $86 \mathrm{Ma}$ & $86 \mathrm{Aa}$ & 96 \\
\hline Médias & & 89 & 83 & & 91 & 83 & & 85 & 89 & \\
\hline C.V.\% & & & 7,58 & & . & 5,44 & & & 6,02 & \\
\hline & $\mathbf{s}_{1}$ & $90 \mathrm{Aa}$ & $69 \mathrm{Bb}$ & 80 & $88 \mathrm{Ba}$ & $61 \mathrm{Bb}$ & 75 & 93 & 62 & $78 \mathrm{~B}$ \\
\hline
\end{tabular}

BR-4

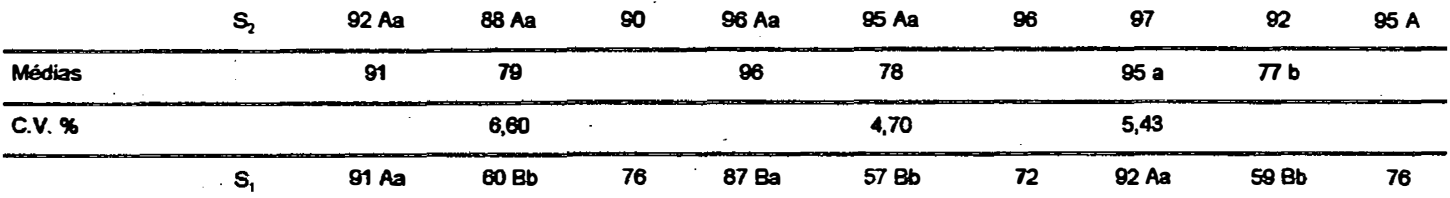
IAS5

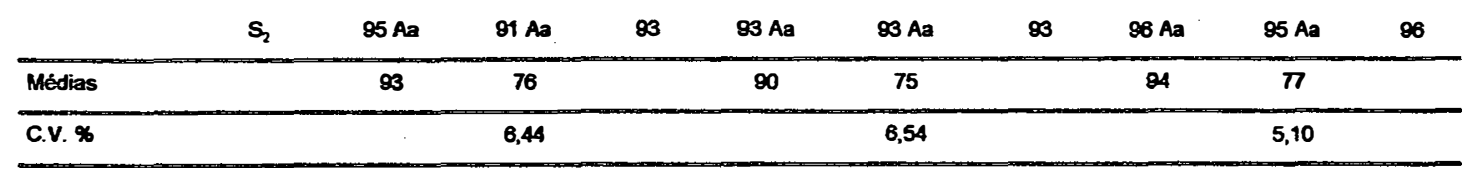

* Para cada cultivar e época de testes, as médias da mesma coluna seguidas pela mesma letra maiúscula ou da mesma linha seguidas pela mesma letra minúscula não diferiram entre si, ao nível de 5\% de probabilidade, pelo teste Tukey • 
Comparando-se as sementes obtidas nas duas semeaduras realizadas em Campinas, constata-se que após o armazenamento (E2), os testes conduzidos para avaliar a qualidade fisiológica das sementes passaram a demonstrar superiorioridade das sementes produzidas em $\mathrm{S}_{2}$ em comparação às obtidas em $\mathrm{S}_{1}$. Assim, o teste de germinação (Tabela 14) revelou este fato para os cultivares 'IACFoscarin-31', 'BR-4' e 'IAS-5'; o teste de envelhecimento artificial (Tabela 15), para todos os cultivares e os testes de tetrazólio 1-5 (Tabela 17) e 1-3 (Tabela 18), para os cultivares 'IAC-Foscarin-31' e 'IAS-5'. O teste de condutividade elétrica (Tabela 16) não foi sensível às diferenças de qualidade das sementes produzidas nas duas épocas, para nenhum cultivar.

Observando-se a Tabela 19, verifica-se que o armazenamento por período mais prolongado e sob condições de temperatura e umidade relativa do ar mais propícias à deterioração das sementes, associado à condição inicial de maior porcentagem de sementes com sintomas de deterioração causada por temperatura e umidade verificados para as sementes obtidas em $S_{1}$, levou a diferenças mais acentuadas quanto à porcentagem de sementes deterioradas colhidas nas duas épocas para todos os cultivares, quando a avaliação da qualidade fisiológica das sementes foi conduzida em $E_{2}$ em comparação à $E_{1}$. 
As condições do ambiente em que foram realizados os testes de emergência de plântulas em campo (Tabela 22), provavelmente, foram bastante. favoráveis à germinação das sementes obtidas em Campinas, resultando em níveis elevados de emergência de plântulas tanto para as sementes colhidas em $S_{1}$ quanto em $S_{2}$. O primeiro teste efetuado (T1) não diferenciou significativamente as médias obtidas para as duas épocas de semeadura para nenhum cultivar. O segundo teste (T2) mostrou superioridade significativa das sementes produzidas em $S_{2}$ para os cultivares 'IAC-Foscarin-31', 'BR-4' e 'IAS-5', confirmando os resultados obtidos no teste de germinação e o terceiro teste (T3) revelou a superioridade das sementes obtidas em $\mathrm{S}_{2}$ para os cultivares 'IAC-16' e 'BR-4'. Cabe salientar entretanto, que de maneira geral, os valores numéricos das médias obtidas para as sementes colhidas em Campinas em' $\mathrm{S}_{1}$ foram inferiores aos das sementes obtidas em $S_{2}$ nos três testes de emergência de plântulas realizados no campo.

Comparando-se as sementes obtidas nas duas semeaduras conduzidas em Votuporanga, nota-se que acentuaram-se ainda mais as diferenças quanto à qualidade fisiológica das sementes produzidas em $S_{1}$ e $S_{2}$ após o armazenamento E2. Da mesma forma que em Campinas, para as sementes obtidas em Votuporanga em $\mathrm{S}_{1}$, associaram-se os efeitos do armazenamento mais prolongado (sob condições de temperatura e umidade relativa do ar favoráveis à deterioração das. sementes) aos maiores níveis de deterioração iniciais causados pelas temperaturas e umidades relativas do ar elevadas em comparação a $\mathrm{S}_{2}$. 
Diversos autores também relataram que períodos chuvosos e com temperaturas elevadas, característicos nas fases de maturação e colheita de soja nas regiões tropicais, dificultam à obtenção de sementes de soja de qualidade aceitável e a manutenção do vigor durante o armazenamento (CARTTER \& HARTWIG, 1962; CAVINESS, 1978; SILVA et al., 1979; HEPPERLY \& SINCLAIR, 1980; DASSOU \& KUENEMAN, 1984; KEIGLEY \& MULLEN, 1986) .

Todos os testes realizados comprovaram isto, demonstrando que, enquanto as sementes produzidas em $\mathrm{S}_{2}$ mantiveram o potencial fisiológico desde a colheita até a época de semeadura da safra seguinte (E2), as sementes obtidas em $\mathrm{S}_{1}$ de todos os cultivares sofreram intensificação do processo de deterioração (mabellas 19 e 20) durante o armazenamento. Este fato foi confirmado pelos testes de emergência de plântulas efetuados no campo, mesmo em condições bastante favoráveis à germinação das sementes (Tabela 22).

Assim, os resultados obtidos neste trabalho concordam com as informações contidas na literatura nacional, que indicam semeaduras mais tardias como mais propicias à produção de sementes de soja de melhor qualidade (PEREIRA et al., 1979; PAOLINELLI et al., 1984b; TRAGNAGO \& BONETTI, 1984; NAKAGAWA et al., 1984a, 1984b e 1986). 
Cabe salientar que, de acordo com os Padrões de Sementes Básicas e Certificadas (SÃO PAULO, S.A.A., 1993), as sementes de todos os cultivares produzidas em $\mathrm{S}_{2}$ em Campinas ou Votuporanga seriam aprovadas, apresentando potenciais de germinação superiores a $85 \%$ quando avaliadas tanto em E1 quanto em E2.

Por outro lado, quando as sementes foram produzidas na época recomendada para semeadura da soja no Estado de São Paulo $\left(\mathrm{S}_{1}\right)$, as colhidas em Campinas atenderiam a esse padrão se avaliadas em El; na avaliação realizada em E2, as sementes do cultivar IAS-5 não seriam aprovadas .

Dentre as sementes produzidas em Votuporanga nesta época $\left(S_{1}\right)$, apenas a's dos cultivares 'IAC-Foscarin31." e 'BR-4' seriam aceitas quando analisadas em E1; pela avaliação conduzida em E2, todas as sementes seriam descartadas.

\subsection{Sanidade das Sementes}

\subsubsection{Sementes atacadas por insetos - percevejos}

Na Tabela 23 encontram-se os níveis de significância relativos aos valores de $\mathrm{F}$, obtidos nas análises de variância dos dados referentes às sementes atacadas por percevejos, observados no teste de tetrazólio. 
Tabela 23. Níveis de significância dos valores de F obtidos nas análises de variância dos dados referentes às sementes atacadas por percevejos, observados no Teste de Tetrazólio.

\begin{tabular}{|c|c|c|c|c|c|}
\hline \multirow{2}{*}{ Cultivares } & \multirow{2}{*}{$\begin{array}{l}\text { Causas de } \\
\text { Variaçåo }\end{array}$} & \multicolumn{2}{|c|}{ Após colheita (E1) } & \multicolumn{2}{|c|}{ Novembro de 1990 (E2) } \\
\hline & & $1-8$ & $6-8$ & $1-8$ & $6-8$ \\
\hline & Local (L) & ns & ns & ns & ns \\
\hline \multirow[t]{3}{*}{ IAC-100 } & Semeadura (S) & $* *$ & ns & ns & ns \\
\hline & Interação (LxS) & ns & ns & * & ns \\
\hline & Local (L) & $\star \star$ & * & $\star \star$ & $*$ \\
\hline \multirow[t]{3}{*}{ IAC-16 } & Semeadura (S) & ns & ns & $\star \star$ & ns \\
\hline & Interação (LxS) & ns & * & * & ns \\
\hline & Local (L) & ns & ns & * & ns \\
\hline \multirow{3}{*}{ IAC-Foscarin-31 } & Semeadura (S) & ns & ns & ns & ns \\
\hline & Interação (LxS) & ns & ns & ns & ns \\
\hline & Local (L) & $\#$ & $\star \star$ & $\star *$ & * \\
\hline \multirow[t]{3}{*}{ BR-4 } & Semeadura (S) & ns & ns & ** & ns \\
\hline & Interaçāo (LxS) & $\star \star$ & ns & $* *$ & ns \\
\hline & Local (L) & * & * & $\star$ & $\star$ \\
\hline \multirow[t]{2}{*}{ IAS-5 } & Semeadura (S) & $\star$ & ns & * & ns \\
\hline & interaçåo (LxS) & $=$ & ns & * & ns \\
\hline
\end{tabular}

ns não significativo

* significativo ao nível de 5\% de probabilidade

* significativo ao nível de $1 \%$ de probabilidade 
A Tabela 24 contém as porcentagens de sementes atacadas por percevejos, incluidas nas classes 1 a 8 durante a avaliação desse teste. Analisando-se esta Tabela constata-se que em $\mathrm{S}_{1}$, os cultivares 'IAC-16', 'IACFoscarin-31' e 'BR-4' apresentaram maiores porcentagens de sementes atacadas por percevejos quando produzidas em Votuporanga em relação à Campinas, em pelo menos uma das épocas de avaliação da qualidade (E1 e E2); porém, não houve diferença significativa entre as médias dos locais para os cultivares 'IAC-100' e 'IAS-5'.

Em $S_{2}$, com exceção apenas do cultivar IAC100, os demais cultivares também apresentaram porcentagens significativamente superiores de sementes atacadas por percevejos quando obtidas em Votuporanga, em pelo menos uma das épocas de avaliação (E1 ou E2).

Considerando-se épocas de semeadura, verifica-se que, de modo geral, não houve diferenças significativas entre as médias de sementes atacadas por percevejos quando produzidas em Campinas. Em Votuporanga, a maioria dos cultivares apresentou médias significativamente superiores para este parâmetro em $\mathrm{S}_{2}$ em comparação à $\mathrm{S}_{1}$, embora as aplicações de inseticida efetuadas sobre a cultura tenham sido mais freqüentes nos dois locais naquela época 
Tabela 24. Teste de Tetrazólio 1-8 (sementes atacadas por percevejos): valores médios (\%) obtidos após a coleita e durante o mês de novembro para cada cultivar de soja, em função de épocas e locais de semeadura.

\begin{tabular}{|c|c|c|c|c|c|c|c|}
\hline \multirow{2}{*}{ Cultivares } & \multirow{2}{*}{$\begin{array}{l}\text { Epocas de } \\
\text { Semeadura }\end{array}$} & \multicolumn{3}{|c|}{ Após colheita (E1) } & \multicolumn{3}{|c|}{ Novembro de 1990 (E2) } \\
\hline & & Campinas & Votuporanga & Médias & Campinas & Votuporanga & Médias \\
\hline & $s_{1}$ & 3 & 4 & $4 B$ & $4 \mathrm{Aa}$ & $3 \mathrm{Ba}$ & 4 \\
\hline \multicolumn{8}{|l|}{ IAC-100 } \\
\hline & $s_{2}$ & 5 & 9 & $7 A$ & $4 \mathrm{Aa}$ & $8 \mathrm{Aa}$ & 6 \\
\hline Médias & & $4 a$ & $7 a$ & & 4 & 6 & \\
\hline C.V. \% & & & 27,33 & & & 42,14 & . \\
\hline & $\mathbf{s}_{1}$ & 4 & 12 & $8 \mathrm{~A}$ & $3 \mathbf{B b}$ & $10 \mathrm{Aa}$ & 7 \\
\hline
\end{tabular}

IAC-16

\begin{tabular}{lccccccc} 
& $S_{2}$ & 7 & 10 & 9 A & 7 Aa & 11 Aa & 9 \\
\hline Médias & & 6 b & 11 a & 5 & 11 \\
\hline C.V.\% & & 23,62 & & 14,79 \\
\hline & $S_{1}$ & 8 & 10 & 9 A & 5 & 8 & 7 A
\end{tabular}

IAC-Foscarin-31

\begin{tabular}{|c|c|c|c|c|c|c|c|}
\hline & $S_{2}$ & 9 & 9 & $9 A$ & 6 & 12 & $9 \mathrm{~A}$ \\
\hline Médias & & 9 a & $10 a$ & & $6 \mathrm{~b}$ & $10 a$ & s \\
\hline C.V. \% & & & 30,98 & & & 25,80 & \\
\hline
\end{tabular}

BR-4

\begin{tabular}{lccccccc} 
& $S_{2}$ & $3 \mathrm{Ab}$ & $19 \mathrm{Aa}$ & 11 & $3 \mathrm{Ab}$ & $19 \mathrm{Aa}$ & 11 \\
\hline Médias & & 4 & 15 & & 4 & 13 \\
\hline C.V. \% & & & 21,41 & & & 25,85 \\
\hline & $\mathrm{S}_{1}$ & $5 \mathrm{Aa}$ & $6 \mathrm{Ba}$ & 6 & $4 \mathrm{Aa}$ & $5 \mathrm{Ba}$ & 5
\end{tabular}

IAS.5

\begin{tabular}{lccccccc} 
& $S_{2}$ & $6 \mathrm{Ab}$ & $17 \mathrm{Aa}$ & 12 & $5 \mathrm{Ab}$ & $11 \mathrm{Aa}$ & 8 \\
\hline Médias & 6 & 12 & 5 & 8 & \\
\hline C.V. \% & & 36,28 & & 24,87 \\
\hline
\end{tabular}

* Para cada cultivar e épocas de testes, as médias da mesma coluna seguidas pela mesma letra maiúscula ou da mesma linha seguidas pela mesma letra minúscula não diferiram entre si, ao nível de 5\% de probabilidade, pelo teste de Tukey • 
Provavelmente, isto deveu-se ao fato de que em $\mathrm{S}_{2}$, a fase reprodutiva da cultura ocorreu na época em que não há lavouras de soja instaladas nessas regiões, de modo que a população de percevejos existente pode ter se transferido para os experimentos. Fato semelhante foi relatado por PEREIRA et al. (1979), no Paraná.

Assim, na presente pesquisa, confirmou-se a necessidade de maior atenção à incidência de percevejos na cultura da soja quando a semeadura é realizada tardiamente, visando preservar a qualidade das sementes produzidas.

Quanto às médias de sementes que perderam a viabilidade devido ao ataque de percevejos e foram incluídas nas classes 6 a 8 do teste de tetrazólio (Tabela 25), nota-se que os valores numéricos foram, de um modo geral, baixos. O ataque de percevejos foi maior em Votuporanga, ocorrendo diferenças significativas para os cultivares 'IAC-16', 'BR-4' e 'IAS-5' em $S_{1}$ e $S_{2}$.

\subsubsection{Sementes infectadas por fungos}

$A^{\circ}$ discussão desse item foi conduzida considerando-se patógenos de campo, fungos de armazenamento e finalmente aqueles considerados saprófitas, de forma a enfocar: em primeiro lugar, os efeitos dos locais e épocas de semeadura estudados sobre a incidência de fungos nas sementes de soja após a colheita (E1) e em segundo lugar, os efeitos do armazenamento dessas sementes, até novembro de 1990 (E2), sobre o comportamento desses fungos. 
Tabela 25. Teste de Tetrazólio 6-8 (perda de viabiliade das sementes devido ao ataque de percevejos): valores médios (\%) obtidos após a colheita e durante o mês de novembro para cada cultivar de soja, em função de épocas e locais de semeadura.

\begin{tabular}{|c|c|c|c|c|c|c|c|}
\hline \multirow[t]{2}{*}{ Cultivares } & \multirow{2}{*}{$\begin{array}{l}\text { Épocas de } \\
\text { Semeadura }\end{array}$} & \multicolumn{3}{|c|}{ Após colheita (E1) } & \multicolumn{3}{|c|}{ Novembro de 1990 (E2) } \\
\hline & & Campinas & Votuporanga & Médias & Campinas & Votuporanga & Médias \\
\hline & $s_{1}$ & 1 & 3 & $2 A$ & 1 & 1 & $1 \mathrm{~A}$ \\
\hline \multicolumn{8}{|l|}{ IAC-100 } \\
\hline & $s_{2}$ & 2 & 4 & $3 \mathrm{~A}$ & 1 & 3 & $2 A$ \\
\hline Médias & & $2 a$ & $4 a$ & & $1 a$ & $2 a$ & \\
\hline C.V. \% & & & 47,77 & & & 67,34 & \\
\hline & $s_{1}$ & $2 A b$ & $7 \mathrm{Aa}$ & 5 & 1 & 6 & $4 \mathrm{~A}$ \\
\hline
\end{tabular}

IAC-16

\begin{tabular}{lccccccc} 
& $S_{2}$ & 3 Aa & 4 Aa & 4 & 2 & 5 & $3 A$ \\
\hline Médias & 3 & 6 & & $2 \mathrm{~b}$ & $6 \mathrm{a}$ & \\
\hline C.V. \% & & 3 & 45,11 & & & 17,44 & \\
\hline & & & 5 & $4 \mathrm{~A}$ & 2 & 4 & $3 \mathrm{~A}$
\end{tabular}

IAC-Foscarin-31

\begin{tabular}{llllllll} 
& $S_{2}$ & 3 & 2 & $3 \mathrm{~A}$ & 2 & 3 & $3 \mathrm{~A}$ \\
\hline Médias & & $3 \mathrm{ii}$ & $4 \mathrm{a}$ & & $2 \mathrm{~b}$ & $4 \mathrm{a}$ & \\
\hline C.V. \% & & 49,60 & & & 51,07 & \\
\hline & $S_{1}$ & 2 & 5 & $4 \mathrm{~A}$ & 2 & 3 & $3 \mathrm{~A}$
\end{tabular}

$B R-4$

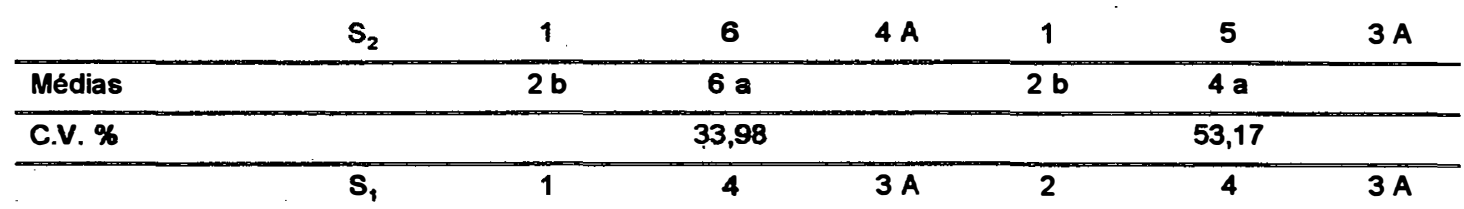

IAS-5

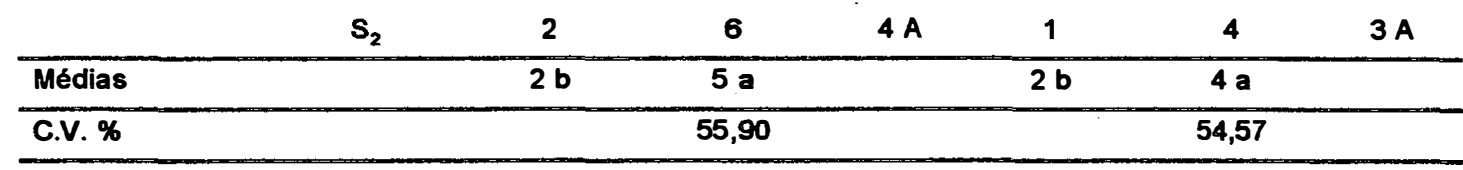

* Para cada cultivar e épocas de testes, as médias da mesma coluna seguidas pela mesma letra maiúscula ou da mesma linha seguidas pela mesma letra minúscula não diferiram entre si, ao nível de 5\% de probabilidade, pelo teste de Tukey • 
Considerando-se $S_{1}$, nota-se que, tanto em Campinas quanto em Votuporanga, as condições do ambiente encontradas nas fases finais do ciclo da cultura da soja caracterizaram-se por temperaturas elevadas e ocorrência de chuvas.

Comparando-se os dois locais, entretanto, constata-se que as condições do ambiente verificadas em Campinas, de modo geral, favoreceram a infecção das sementes pelos principais patógenos causadores de doenças na soja. Examinando-se as Figuras 1 e 2, observa-se maior freqüência e volume de precipitações pluviais coincidindo com o período final de maturação da cultura e colheita das sementes em Campinas; este fato, associado a temperaturas um pouco mais baixas encontradas neste local, provavelmente conduziu a umidades relativas do ar mais elevadas nesta época em Campinas em comparação à Votuporanga. Segundo TANAKA et al. (1984) e JORDAN et al. (1988), tais condições são ideais à intensa atividade de patógenos nas sementes.

Quanto aos patógenos comumente causadores de doenças na soja, de acordo com HENNING (1987), constatou-se na presente pequisa, que Phomopsis sojae (Figura 7) foi o observado com maior freqüência nas sementes de soja após a colheita (E1), concordando com as informações contidaş na literatura (ELLIS et al., 1974; BOLKAN et al., 1976; HEPPERLY \& SINCLAIR, 1981; FRANÇA NETO \& WEST, 1989a e OSORIO \& MCGEE, 1992). 


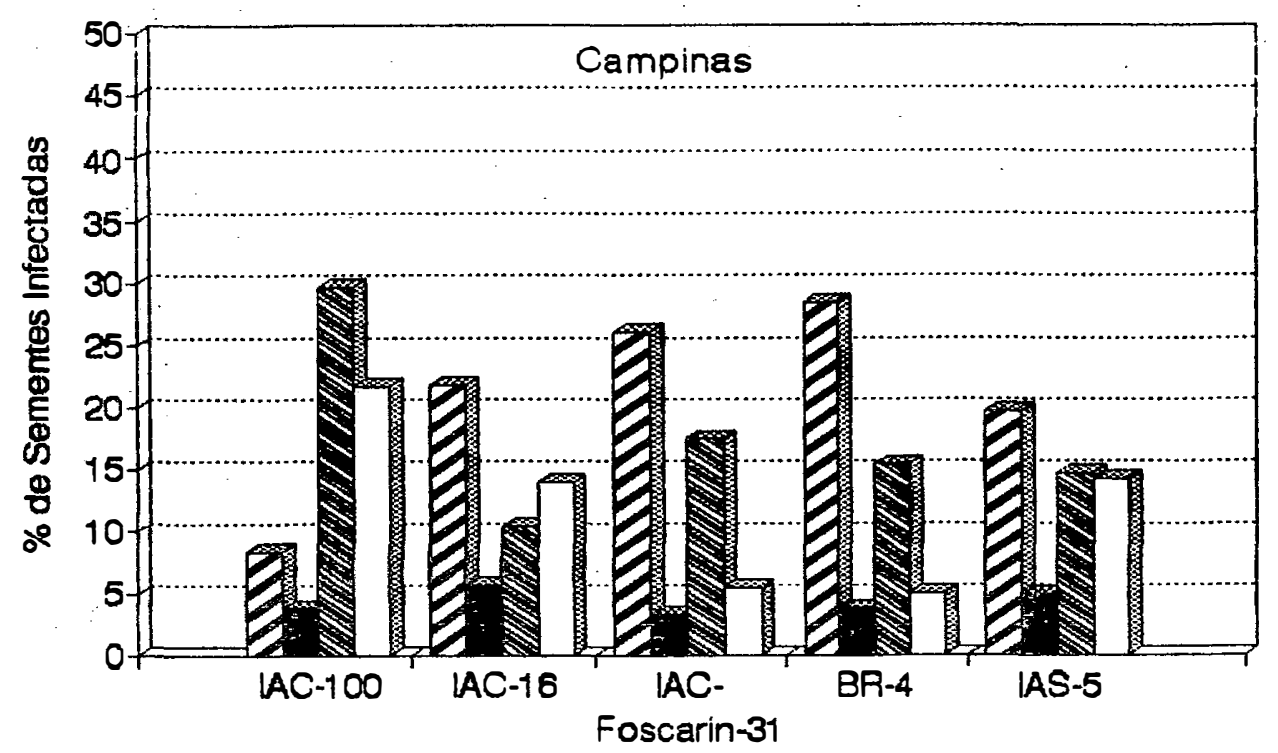

DS1-E1 S1-E2 S2-E1 $\square$ S2-E2

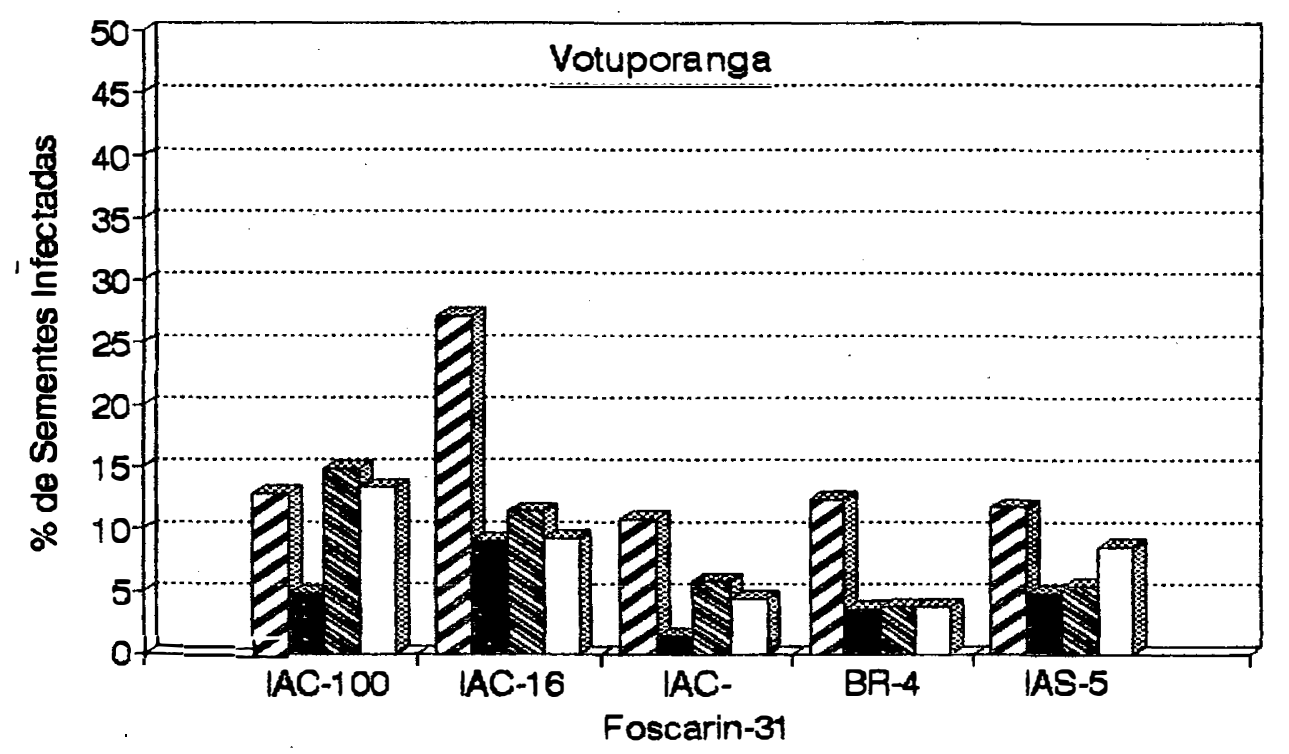

QS1-E1 ES S1E2 S2-E1 $\square$ S2-E2

Figuxa 7. Valores médios $(\gamma)$ de sementes infectadas por sojae, obtidos em função de épocas de semeadura e de épocas de teste, 1990. 
Diversos autores também verificaram 0 aumento da incidência de Phomopsis spp (DHINGRA et al., 1978; SHORTT et al., 1981; SPILKER et al., 1981; WILCOX et al., 1985; RUPE \& FERRIS, 1986 e BALDUCCHI-\& MCGEE, 1987), de Cercospora kikuchii (JORDAN et al., 1988) e de Fusarium spp (DHINGRA, 1978) nas sementes de soja, causada pela ocorrência de chuvas.

Assim, constatou-se no presente trabalho, que em $S_{1}$ foram colhidas maiores porcentagens de sementes infectadas por Phomopsis sojae (Figura 7) em Campinas, para os cultivares 'IAC-Foscarin-31', 'BR-4' e 'IAS-5', sendo que para o 'IAC-100' e o 'IAC-16', as diferenças observadas entre os doiß̉ locais não foram consideráveis.

Embora apresentando incidência bem mais baixa nas sementes em relação a Phomopsis sojae, o fungo Colletotrichum dematium (Figura 8) ocorreu nas sementes de todos os cultivares produzidas em Campinas, enquanto que, em Votuporanga, ocorreu apenas nas sementes do 'IAC-16'.

A incidência de Cercospora kikuchii (Figura 9) também se destacou nas sementes obtidas em Campinas, com exceção apenas do cultivar IAC-100, que apresentou níveis muito baixos de sementes infectadas por esse fungo nos dois locais. 


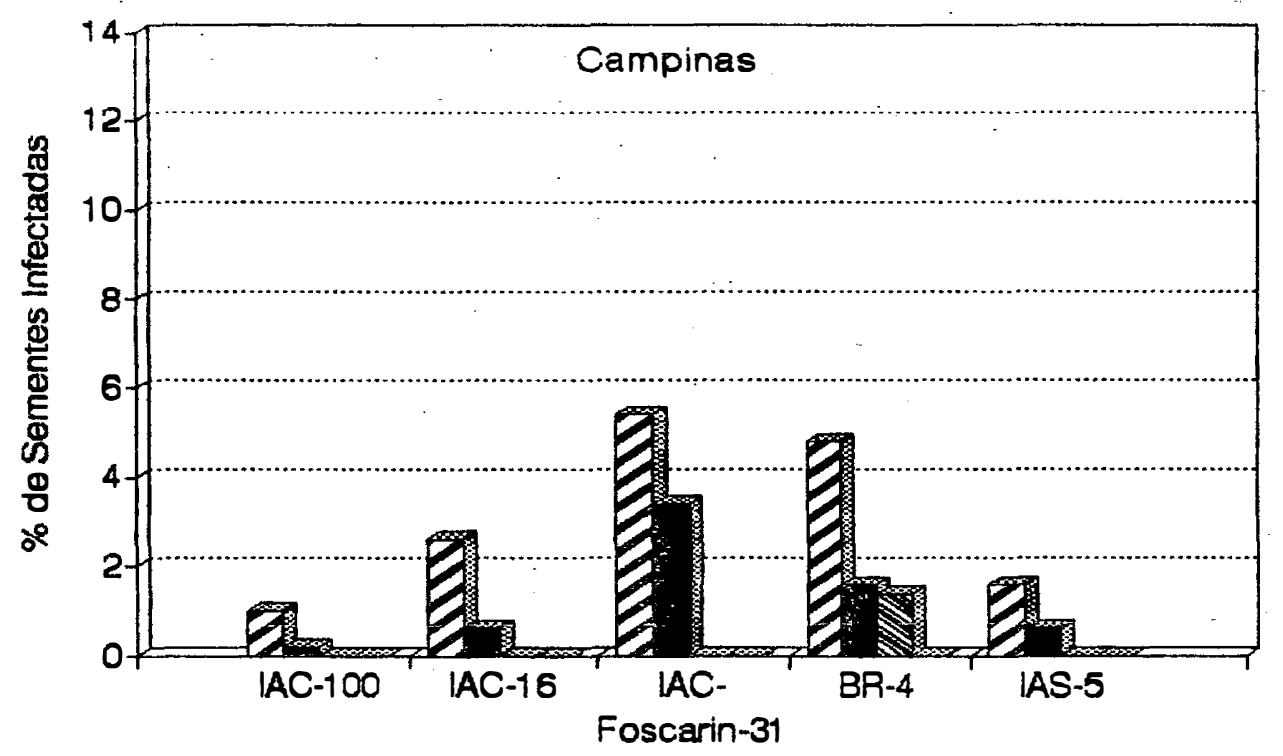

ZS1-E1 S1E2 S2-E1 $\square$ S2E2

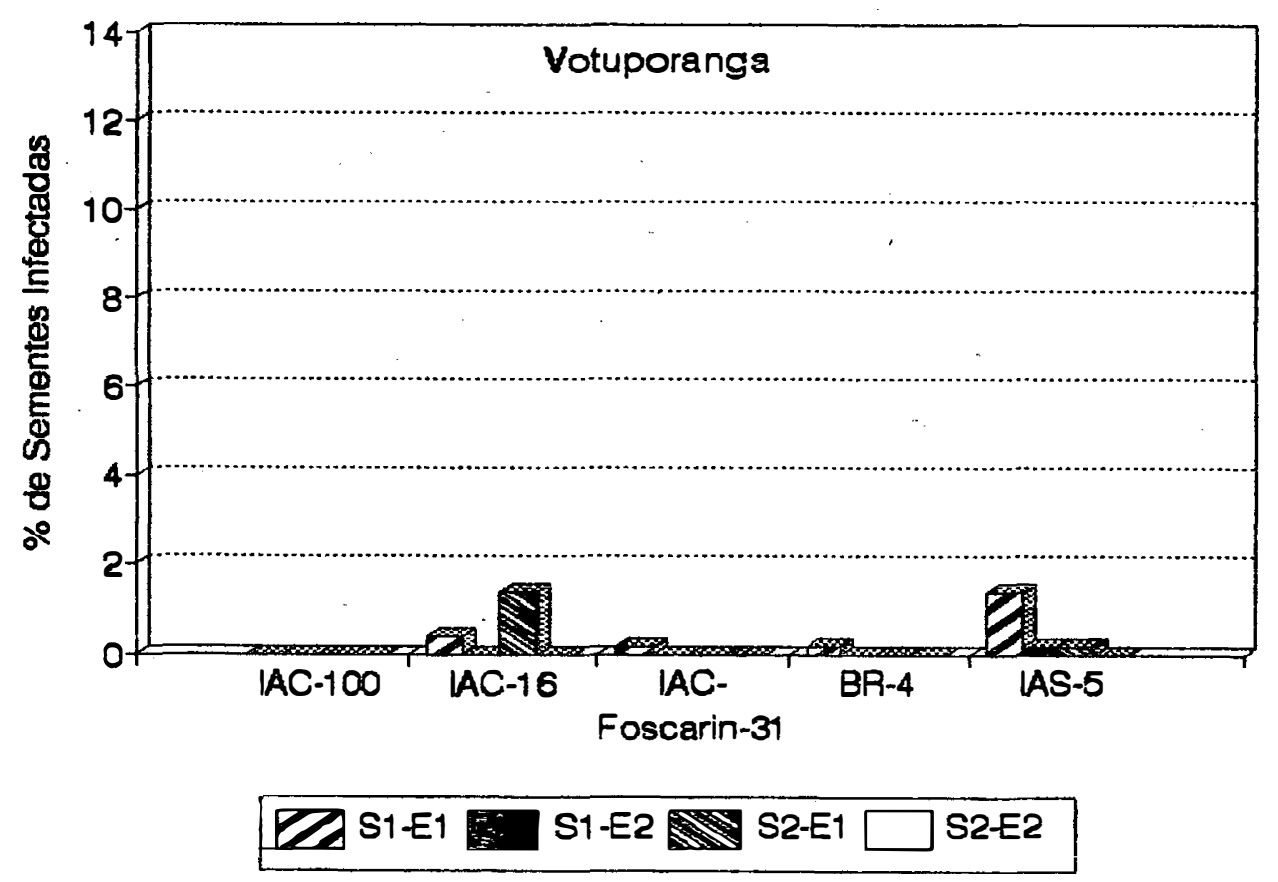

Figura 8. Valores médios $(\%)$ de sementes infectadas por Colletotrichum dematium, obtidos em função de épocas de semeadura e de épocas de teste, 1990. 


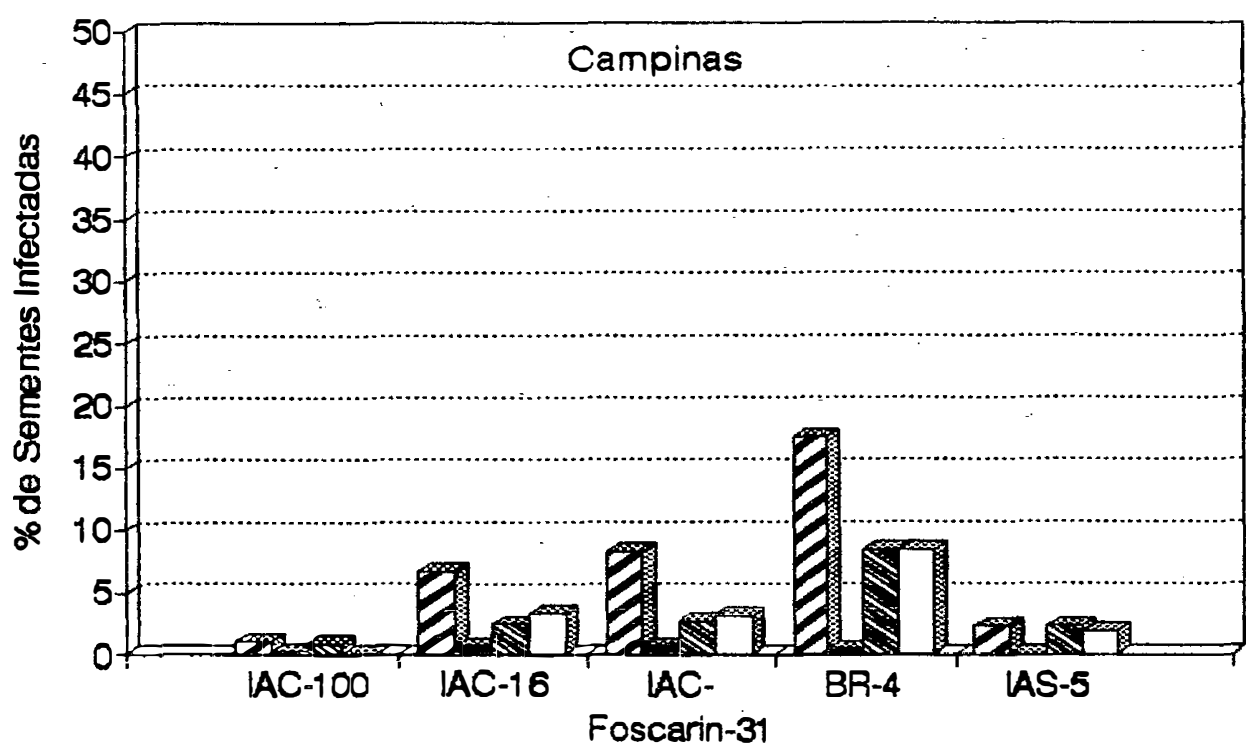

\section{S1E1 S1-E2 S2-E1 $\square$ S2-E2}

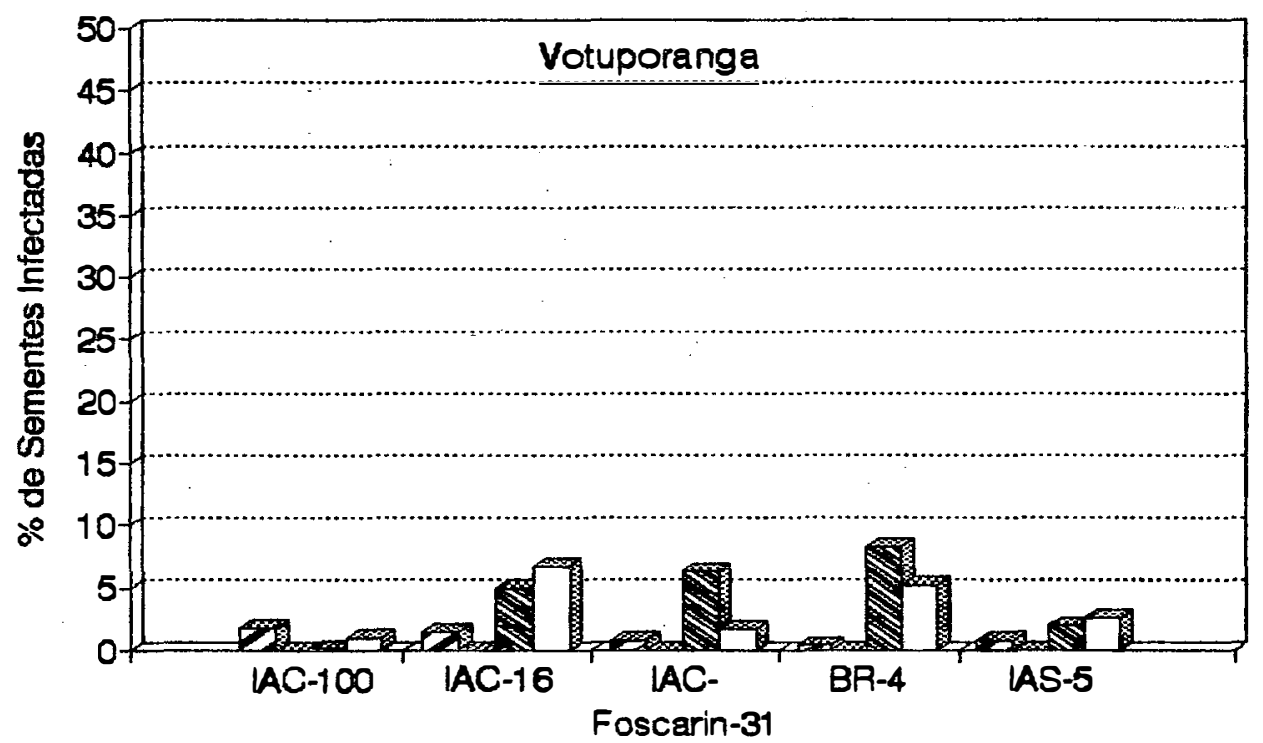

\section{S1-E1 S1-E2 S2E1 $\square$ S2-E2}

Figura 9. Valores médios $(z)$ de sementes infectadas por Cercospora kikuchii, obtidos em função de épocas de semeadura e de épocas de teste, 1990. 
Por outro lado, examinando-se a Figura 10, nota-se que a ocorrência de sementes infectadas por Fusarium spp foi superior em Campinas apenas para o cultivar IAC-Foscarin-31; para O 'IAC-100' não se observaram diferenças relevantes entre os dois locais, e para os demais cultivares ('IAC-16', 'BR-4' e 'IAS-5'), foram produzidas porcentagens maiores de sementes infectadas por esse fungo em Votuporanga.

Porém, vale salientar que, de modo geral, as condições do ambiente observadas em Votuporanga, menos favoráveis ao crescimento de fungos em comparação à Campinas, também prejudicaram a qualidade fisiológica das sementes (Tabelas 14, 15, 16, 17, 18, 19, 20 e 22). Segundo DHINGRA et al. (1978), diversas espécies de Fusarium são comumente observadas em sementes de soja com baixo poder germinativo. Assim, a maior incidência de Fusarium spp nas sementes produzidas em Votuporanga deve ter sido associada à pior qualidade fisiológica das sementes obtidas neste local.

Myrothecium spp, embora patogênicos às sementes de soja, tiveram ocorrência reduzida no presente trabalho. Através da Figura 11, observa-se que não ocorreram diferenças relevantes entre os dois locais quanto à incidência desse fungo nas sementes produzidas em $\mathrm{S}_{1}$; nesta época, apenas o cultivar IAC-100 praticamente não apresentou sementes infectadas por esse fungo em Votuporanga. 


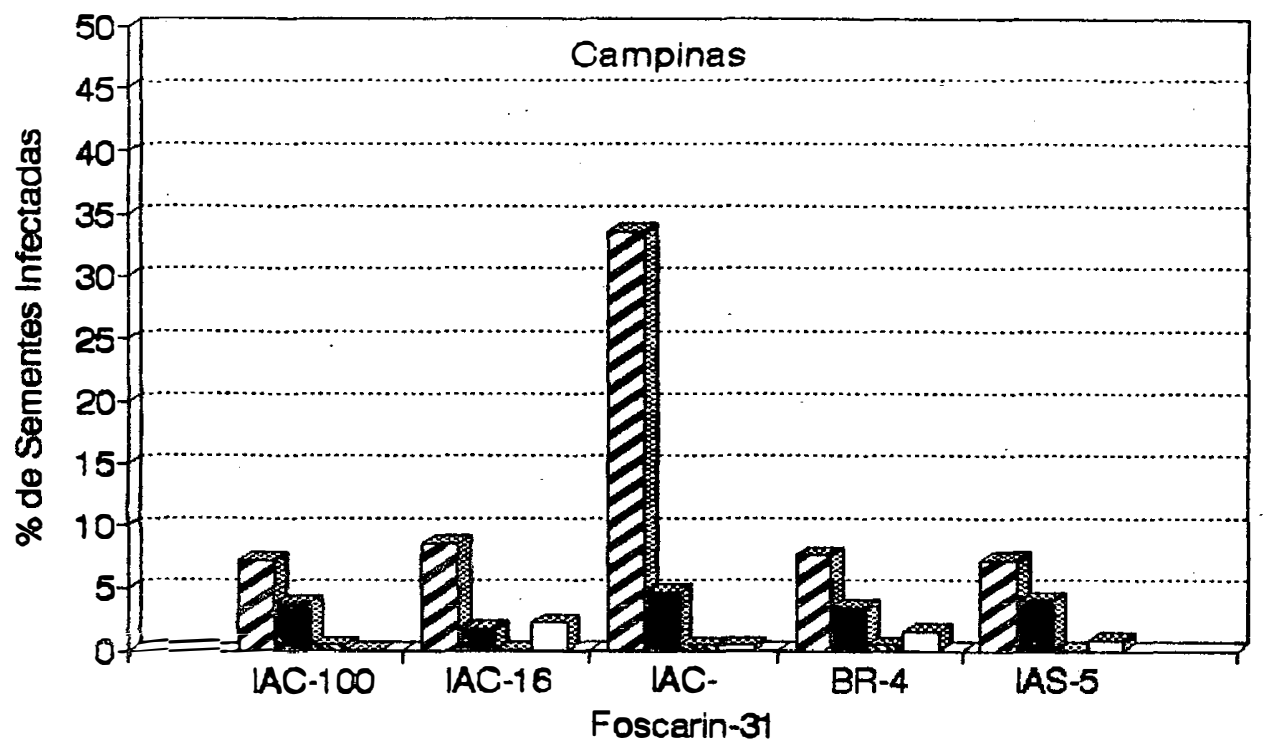

S1E1 S1E2 S2E1 $\square$ S2E2

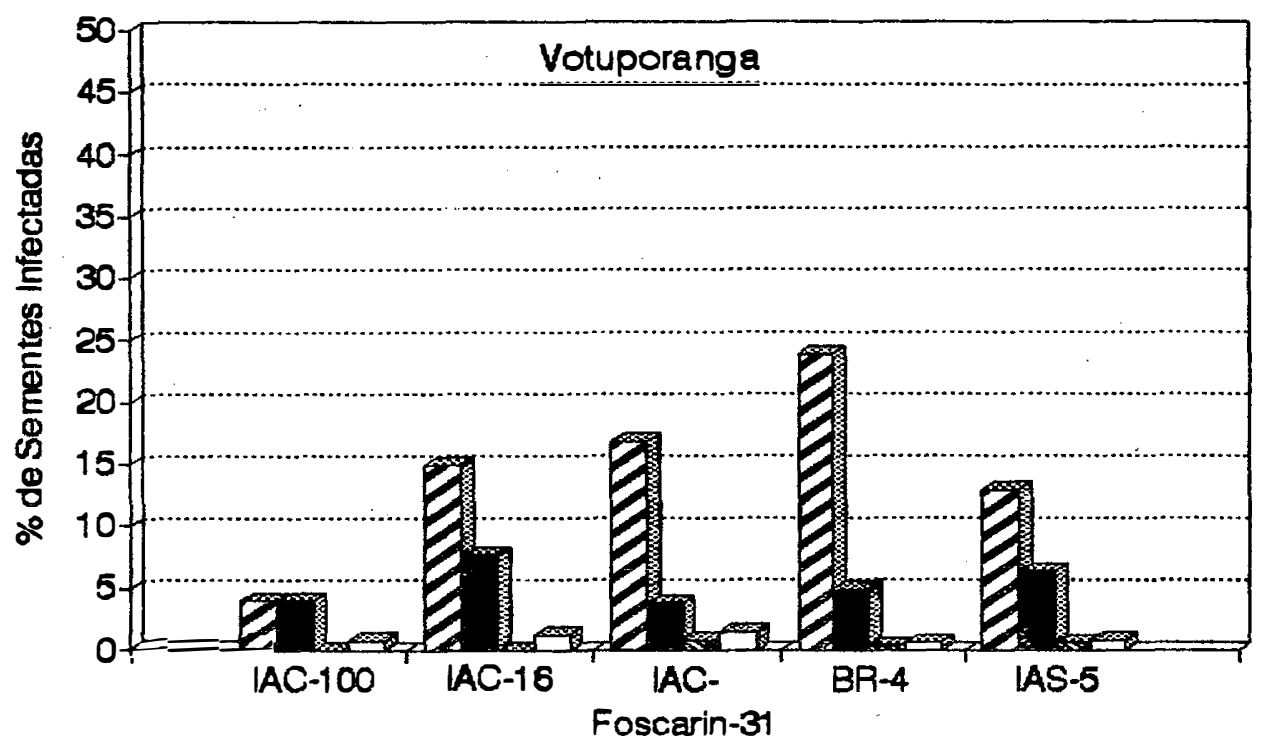

S1-E1 S1-E2 S2-E1 $\square$ S2-E2

Figura 10. Valores médios (z) de sementes infectadas por Fusarium spp, obtidos em função de épocas de semeadura e de épocas de teste, 1990. 


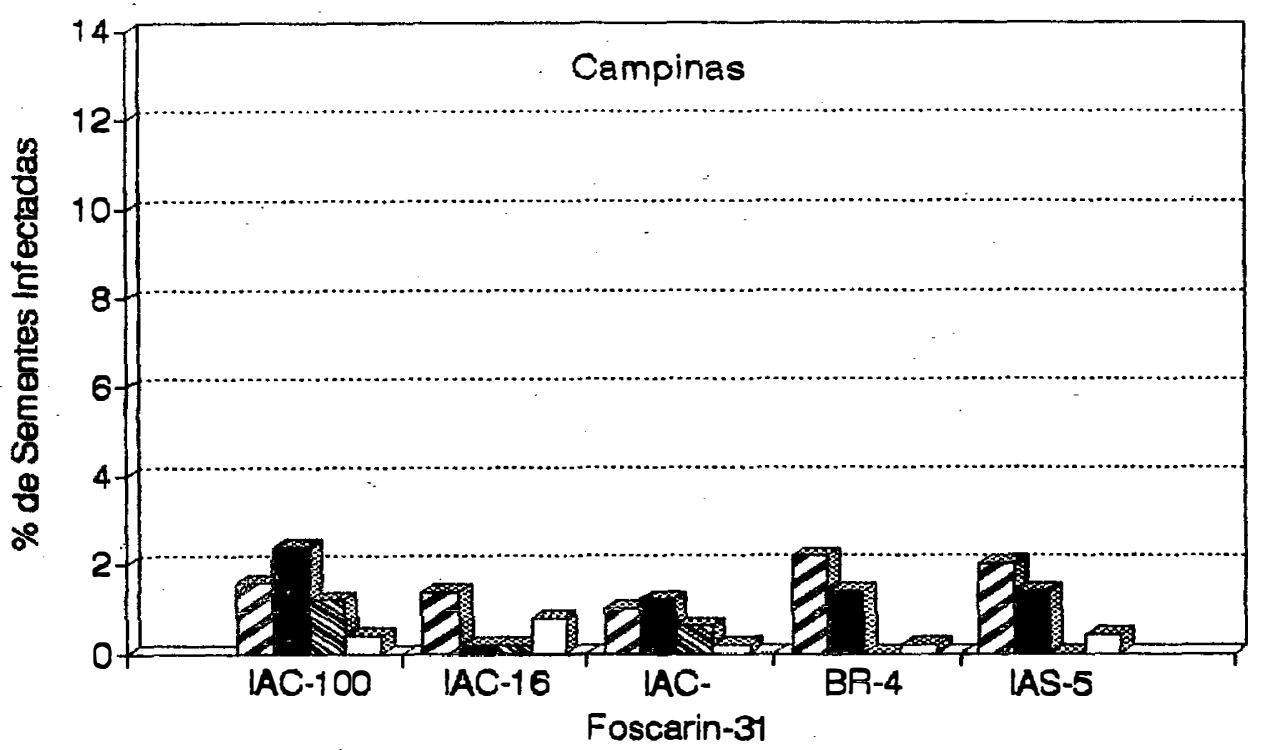

ZS1-E1 S1-E2 S2E1 $\square$ S2E2

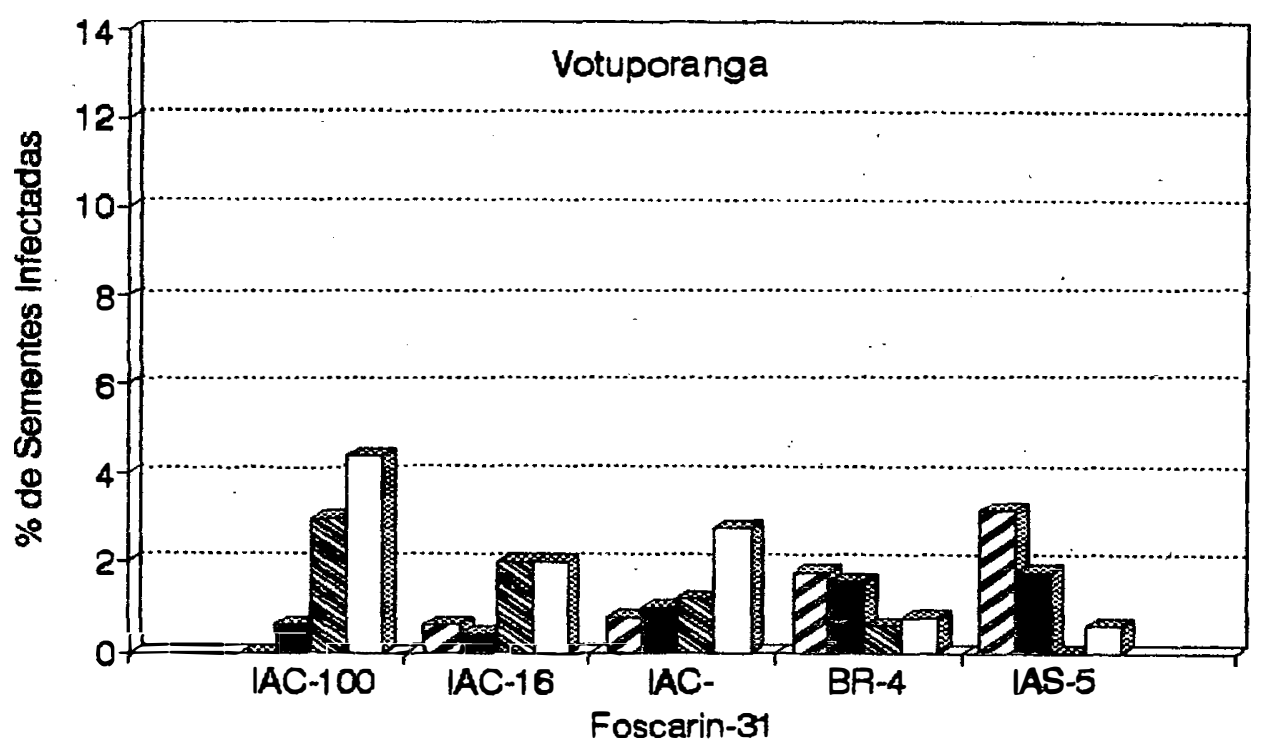

S1E1 S1-E2 S2-E1 $\square$ S2-E2

Figura 11. Valores médios $(z)$ de sementes infectadas por Myrothecium spp, obtidos em função de épocas de semeadura e de épocas de teste, 1990. 
Macrophomina phaseolina foi o patógeno que menos incidiu sobre as sementes produzidas nesta pesquisa (Figura 12), ocorrendo espordicamente apenas em $S_{1}$ e em cultivares diferentes em cada local estudado.

Considerando-se $\mathrm{S}_{2}$, observa-se que as condições do ambiente, que coincidiram com $\circ$ período de maturação das sementes de soja, caracterizaram-se por época seca e de temperaturas visivelmente mais baixas tanto em Campinas (Figura 3) quanto em Votuporanga (Figura 4) em comparação à $S_{1}$. Estas condições desfavoráveis à atividade de fungos permitiram a obtenção de sementes com maior qualidade sanitária em $\mathrm{S}_{2}$ nos dois locais estudados.

Este fato foi demonstrado nitidamente no presente trabalho; examinando-se a Figura 7 observa-se que, com exceção apenas do cultivar IAC-100, as sementes colhidas em $\mathrm{S}_{2}$ apresentaram menor incidência de Phomopsis sojae nos dois locais avaliados, concordando com diversos autores (ELLIS et al., 1974; BOLKAN et al., 1976; HEPPERLY \& SINCLAIR, 1981; FRANÇA NETO \& WEST, 1989a e OSORIO \& MCGEE, 1992).

Entretanto, na ocasião da colheita, observou-se acentuada retenção foliar nas plantas do cultivar IAC-100 em $\mathrm{S}_{2}$ nos dois locais estudados. É provável que esta característica tenha resultado em microclima mais úmido ao redor das plantas, propiciando perda mais lenta de umidade das sementes para o ambiente e favorecendo o desenvolvimento de Phomopsis sojae. Retenção foliar influenciando o teor de água das sementes e levando à maior incidência de patógenos também foi verificada por FRANÇA NETO et al. (1984). 


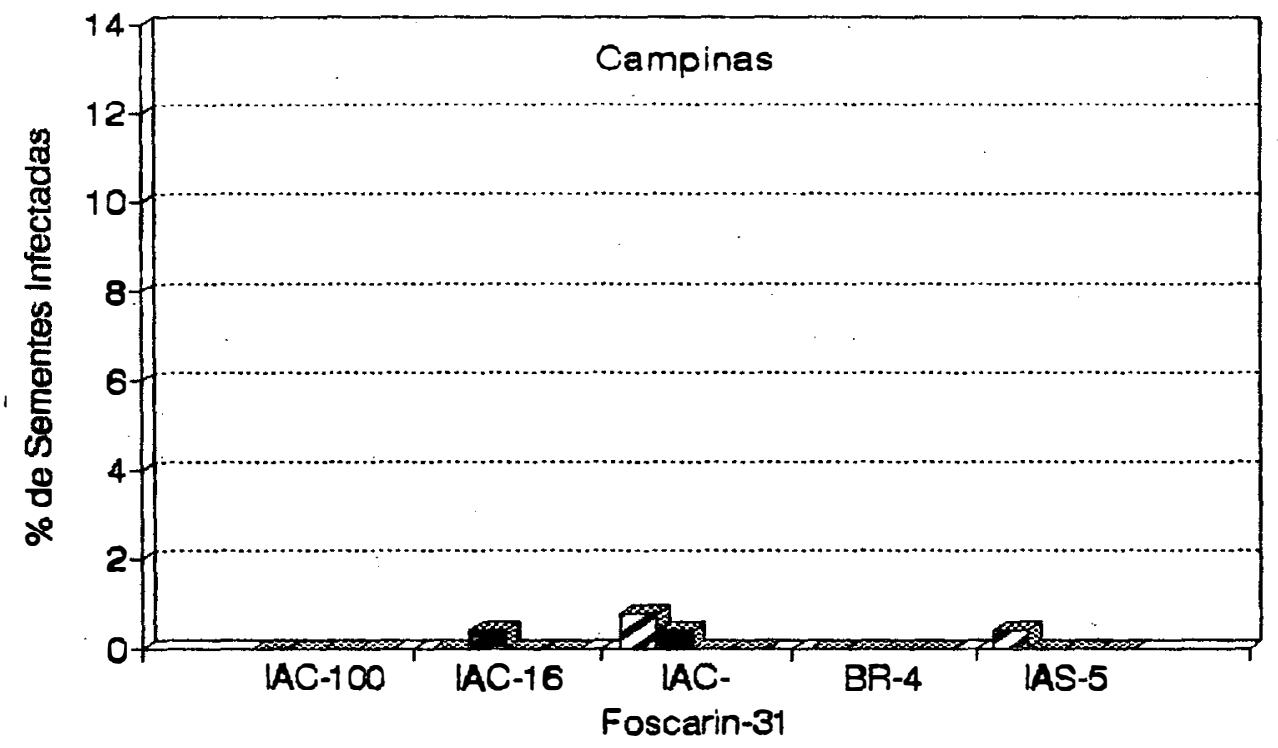

S1-E1 $=$ S1-E2 S2-E1 $\square$ S2-E2

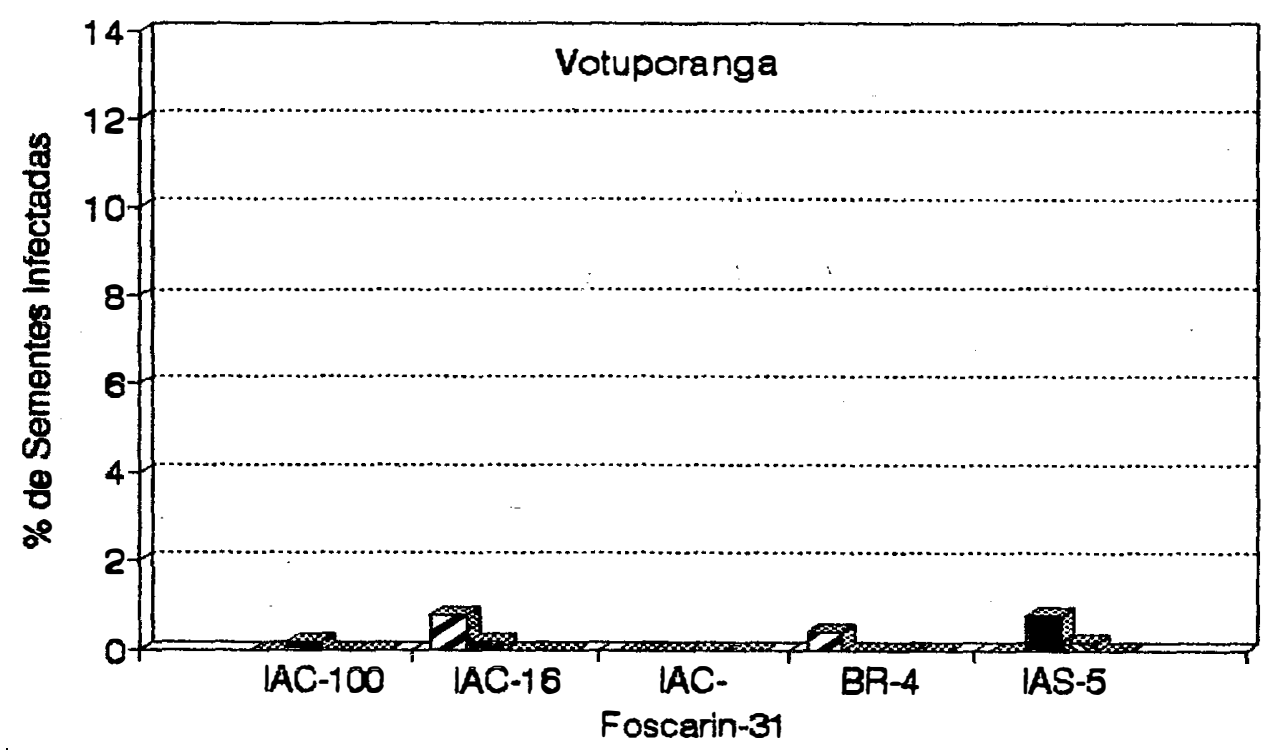

S1-E1 S1-E2 S2-E1 $\square$ S2E2

Figura 12. Valores médios (z) de sementes infectadas por Macrophomina phaseolina, obtidos em função de épocas de semeadura e de épocas de teste, 1990. 
Confirmando esta observação, nas Figuras 2 e 4, nota-se que em Votuporanga, onde todas as outras fases do ciclo da cultura reduziram-se em $\mathrm{S}_{2}$ para o cultivar IAC100, o período entre R7 e R8 foi superior nesta época, provavelmente, em conseqüência da retenção foliar.

Contrariando os resultados obtidos por DHINGRA. et al. (1979b), que não demonstraram diferenças quanto ao nível de ocorrência de Colletotrichum dematium em sementes de cultivares de soja de diversos grupos de maturação e produzidas em duas épocas diferentes, na presente pesquisa observou-se que, em $\mathrm{S}_{2}$ a incidência desse fungo passou a ser esporádica nas sementes produzidas, ocorrendo apenas para os cultivares BR-4 em Campinas e IAC16 em Votuporanga, em níveis inferiores a $2 \%$ (Figura 8).

Da mesma forma, notou-se que Fusarium spp (Figura 10) teve incidência reduzida nas sementes de todos os cultivares produzidas nos dois locais estudados em $\mathrm{S}_{2}$ em comparação à $S_{1}$. Os fungos Myrothecium spp (Figura 11) também ocorreram em menores níveis nas sementes de todos os cultivares obtidas em Campinas e nas sementes dos cultivares 'BR-4' e 'IAS-5' produzidas em Votuporanga, em $\mathrm{S}_{2}$. Ainda, Macrophomina phaseolina (Figura 12) praticamente não foi encontrado nas sementes obtidas nos dois locais nesta época. 
Para o fungo Cercospora kikuchii (Figura 9), constatou-se que os efeitos de época de semeadura não foram tão evidentes quantó para os demais fungos de campo analisados. Em Campinas, a incidência de C. Kikuchii foi inferior em $S_{2}$ em comparação a $S_{1}$, 0 que representa comportamento semelhante ao dos demais patógenos de campo encontrados nessas sementes. Por outro lado, em Votuporanga esta situação inverteu-se, e a incidência deste fungo nas sementes, de modo geral, foi superior em $S_{2}$, ressaltando-se que em $S_{1}$ foi praticamente nula. Na literatura também há controvérsias quanto aos efeitos de épocas de semeadura sobre o comportamento de Cercospora kikuchii (KILPATRICK \& HARTWIG, 1955; NICHOLSON \& SINCLAIR, 1973; JORDAN et al., 1988) •

Atualmente, é conhecido o fato de que Phomopsis sojae perde sua viabilidade rapidamente durante - armazenamento, ocorrendo ao mesmo tempo aumento gradual na porcentagem de germinação em laboratório (HENNING \& FRANÇA NETO, 1980) •

De acordo com WETZEL (1987), os patógenos de campo requerem umidade relativa em torno de 90-95\% para crescerem. Analisando-se a figura 6 , nota-se que durante 0 armazenamento das sementes em Campinas, obtidas nas duas épocas, a umidade relativa média não atingiu estes valores. 
Assim, no presente trabalho observando-se a Figura 7, constata-se que o armazenamento mais longo a que foram submetidas as sementes colhidas em $S_{1}$ levou à redução mais acentuada na incidência de $P$. Sojae nas sementes obtidas nos dois locais em comparação às produzidas em $\mathrm{S}_{2}$. Portanto, quando a avaliação da sanidade das sementes foi realizada em E2, as sementes produzidas em $\mathrm{S}_{2}$ apresentaram maiores índices de sementes infectadas por Phomopsis sojae do que as obtidas em $\mathrm{S}_{1}$, embora estas tivessem apresentado maiores níveis de infecção por este fungo após a colheita. o armazenamento das sementes também reduziu nível de incidência de Colletotrichum dematium nas sementes de soja (Figura 8). Porém, na avaliação conduzida em E2, enquanto as sementes colhidas em Campinas em $\mathrm{S}_{1}$ ainda apresentavam sementes infectadas por esse fungo, as obtidas neste local em $\mathrm{S}_{2}$ mostraram-se totalmente livres dele. As colhidas em Votuporanga nas duas épocas não apresentaram incidência de $C$. dematium nas sementes na avaliação de sanidade efetuada em E2.

o armazenamento de 8 meses a que foram submetidas as sementes de soja produzidas em $S_{1}$ resultou em perda da viabilidade de C. kikuchii (Figura 9) considerando-se os dois locais estudados. No entanto, o armazenamento mais curto (em torno de 4 meses) não foi suficiente para reduzir o nível de incidência desse fungo nas sementes de soja produzidas em $\mathrm{S}_{2}$. Desta forma, à 
semelhança do que se observou para $P$. sojae, em E2 as sementes produzidas em $\mathrm{S}_{2}$ apresentaram níveis maiores de sementes infectadas por $C$. kikuchii em comparação às obtidas em $\mathrm{S}_{1}$.

Por outro lado, Fusarium spp (Figura 10) ocorreram principalmente nas sementes produzidas em $\mathrm{S}_{1}$ e mesmo o armazenamento mais prolongado não foi suficiente para reduzir a ocorrência desses fungos, a níveis tão baixos quanto aos das sementes produzidas em $S_{2}$, na avaliação efetuada em E2.

Ainda, após o armazenamento das sementes (E2), nota-se que Myrothecium spp (Figura 11), embora com baixa incidência nesta pesquisa, não demonstraram nitidamente tendência de perda de viabilidade quando as sementes foram produzidas em: $S_{1}$. Para as sementes produzidas em $\mathrm{S}_{2}$, o armazenamento, de modo geral, até aumentou a incidência desses fungos nas sementes.

Macrophomina phaseolina (Figura 12), que só ocorreu em $S_{1}$ e em níveis reduzidos, não desapareceu após o armazenamento.

Embora, de acordo com HENNING (1987), nem todas as sementes infectadas por C. Kikuchii apresentem manchas de coloração púrpura no tegumento e na presente pesquisa já tenham sido incluídos resultados de infecção das sementes por este fungo, obtidos através do teste do 
papel de filtro, a presença de sementes com tal sintoma deprecia a qualidade de um lote de sementes de soja. Tanto é que nos padrões de sementes básicas e certificadas (SÃO PAULO, 1993) 5\% é considerado o limite máximo aceitável de sementes com coloração púrpura no tegumento. Assim, foi efetuada também a avaliação visual de sementes com mancha púrpura.

Comparando-se os resultados contidos na Tabela 26 aos da Figura 9, nota-se que as diferenças entre locais e épocas de semeadura foram identificadas de modo semelhante pelos dois métodos de avaliação; confirmando o comentário de HENNING (1987), os valores obtidos através do teste de papel de filtro (Figura 9) foram, de modo geral, superiores aos de sementes manchadas (Tabela 26).

Examinando-se a Tabela 26, observa-se que o cultivar IAC-100 destacou-se, apresentando os menores níveis de sementes com mancha púrpura; praticamente não ocorreram diferenças entre as médias obtidas para as épocas de semeadura ou para os locais estudados quanto a este parâmetro.

Por outro lado, os cultivares BR-4, IACFoscarin-31 e IAC-16, nesta ordem, foram os que apresentaram maior ocorrência de sementes coloridas de púrpura quando produzidas em Campinas em $\mathrm{S}_{1}$. Inclusive, as sementes obtidas para os dois primeiros cultivares não teriam sido aprovadas de acordo com os padrões já mencionados. 
Tabela 26. Sementes com mancha púrpura: valores médios (\%) obtidos para cada cultivar de soja em função de épocas e locais de semeadura.

\begin{tabular}{lcccc}
\hline Cultivares & $\begin{array}{c}\text { Épocas de } \\
\text { Semeadura }\end{array}$ & Campinas & Votuporanga & Médias \\
\hline IAC-100 & $S_{1}$ & 0,24 & 0,00 & 0,12 \\
& $S_{2}$ & 0,05 & 0,10 & 0,08 \\
\hline Médias & & 0,15 & 0,05 & \\
\hline & $S_{1}$ & 4,60 & 1,01 & 2,85
\end{tabular}

IAC-16

\begin{tabular}{lcccc} 
& $S_{2}$ & 0,46 & 0,50 & 0,48 \\
\hline Médias & & 2,53 & 0,76 & \\
\hline & $S_{1}$ & 7,24 & 0,38 & 3,81
\end{tabular}

IAC-Foscarin-31

\begin{tabular}{lcccc} 
& $S_{2}$ & 0,30 & 0,50 & 0,40 \\
\hline Médias & 3,77 & 0,44 & \\
\hline & $S_{1}$ & 12,46 & 0,46 & 6,46
\end{tabular}

BR-4

\begin{tabular}{lcccc} 
& $S_{2}$ & 2,44 & 3,30 & 2,87 \\
\hline Médias & & 7,45 & 1,88 & \\
\hline & $s_{1}$ & 0,93 & 1,00 & 0,97
\end{tabular}

IAS-5

$\begin{array}{llll}S_{2} & 0,16 & 0,24 & 0,20\end{array}$

$0,55 \quad 0,62$


Provavelmente, as condições mais úmidas em que foram produzidas as sementes de soja em Campinas em $\mathrm{S}_{1}$ levaram a este resultado. Em $\mathrm{S}_{2}$, o clima mais seco e frio durante as fases finais do ciclo da cultura permitiram a obtenção de sementes com menores níveis de ocorrência de mancha púrpura. Em Votuporanga, o efeito de épocas de semeadura sobre a ocorrência de $C$. kikuchii não foi tão evidenciado, como já foi discutido no ítem anterior.

O teste do papel de filtro não é eficiente para detectar a presença de fungos causadores de Míldio nas sementes, segundo YORINORI (1987). Assim, na presente pesquisa foi incluída apenas a avaliação visual da crosta esbranquiçada formada por oósporos de Peronospora manshurica sobre as sementes de soja e realizada após a colheita (E1).

Através do exame da Tabela 27 nota-se que o cultivar IAC-100 novamente destacou-se, apresentando as menores médias de ocorrência desse fungo sobre as sementes. Observa-se que, enquanto em $\mathrm{S}_{1}$, de modo geral, as maiores porcentagens de sementes infectadas por esse fungo foram obtidas em Votuporanga, em $S_{2}$ as sementes infectadas prevaleceram quando a produção de sementes deuse em Campinas. 
Tabela 27. Sementes com ooporosos de Peronospora manshurica: valores médios (\%) obtidos para cada cultivar de soja, em função de épocas e locais semeadura.

\begin{tabular}{ccccc}
\hline Cultivares & $\begin{array}{c}\text { Épocas de } \\
\text { Semeadura }\end{array}$ & Campinas & Votuporanga & Médias \\
\hline $\mathrm{S}_{1}$ & 0,34 & 0,93 & 0,64
\end{tabular}

IAC-100

\begin{tabular}{lcccc} 
& $S_{2}$ & 3,39 & 0,24 & 1,82 \\
\hline Médias & & 1,87 & 0,59 & \\
\hline & $S_{1}$ & 3,91 & 5,21 & 4,56
\end{tabular}

IAC-16

\begin{tabular}{lllll} 
& $S_{2}$ & 20,67 & 0,27 & 10,47 \\
\hline Médias & & 12,29 & 2,74 & \\
\hline & $S_{1}$ & 0,20 & 3,03 & 1,64
\end{tabular}

IAC-Foscarin-31

\begin{tabular}{lllll} 
& $S_{2}$ & 16,11 & 0,00 & 8,06 \\
\hline Médias & & 8,16 & 1,54 & \\
\hline & $S_{1}$ & 1,01 & 2,30 & 1,66
\end{tabular}

BR-4

\begin{tabular}{lllll} 
& $S_{2}$ & 8,47 & 4,21 & 6,34 \\
\hline Médias & & 4,74 & 3,26 & \\
\hline & $S_{1}$ & 2,08 & 5,87 & 3,98
\end{tabular}

IAS-5

$\begin{array}{llll}S_{2} & 15,42 & 1,01 & 8,22\end{array}$

$8,75 \quad 3,44$


Ainda, os níveis de sementes cobertas por oósporos de $P$. manshurica observados em Campinas em $\mathrm{S}_{2}$, (quando a maturaçào e colheita das sementes ocorreu sob clima mais frio) destacaram-se dos níveis obtidos em Campinas em $S_{1}$ e dos níveis obtidos em Votuporanga nas duas semeaduras. Na literatura há referência de incidência relevante desse fungo, prejudicando a qualidade das sementes de soja em semeadura realizada no mês de janeiro em comparação a outras conduzidas a partir de novembro, em apenas um entre dois anos experimentais (BUENO et al., 1975).

Por outro lado, segundo FERREIRA et al. (1981), a maioria das sementes incrustradas de oósporos dá origem a plantas normais, sadias; poucas não chegam a produzir plântulas e apenas algumas produzem plantas sistemicamente infectadas.

$\mathrm{Na}$ presente pesquisa, os excelentes resultados obtidos quanto à qualidade fisiológica, incluindo a emergência de plântulas em campo das sementes produzidas em Campinas na semeadura tardia $\left(S_{2}\right)$ não foram influenciados pela presença de oósporos de Peronospora manshurica sobre as sementes.

Assim, considerando-se, de modo geral, os patógenos que se desenvolveram nas sementes de soja nas fases finais do ciclo da cultura, nota-se que as condições de clima mais seco e de temperaturas mais amenas verificadas na semeadura tardia, desfavorecendo a atividade desses fungos, possibilitaram a obtenção de sementes de soja mais sadias. 
Embora o armazenamento das sementes obtidas em $S_{1}$, mais prolongado até a época recomendada para plantio (E2) em comparação ao das sementes colhidas em $\mathrm{S}_{2}$, tenha resultado em maior redução no nível de incidência de patógenos importantes como $P$. sojae e $C$. Kikuchii nesta ocasião (E2), as sementes colhidas em $S_{2}$ mostraram-se livres de outros patógenos igualmente prejudiciais à sanidade das sementes, como $C$. dematium, Fusarium spp e $M$. phaseolina.

Normalmente, os fungos de armazenamento não invadem as sementes antes da colheita; entretanto, têm sido encontrados em sementes recém-colhidas em porcentagens baixas, em torno de 1\% (WETZEl, 1987).

$\mathrm{Na}$ presente pesquisa, considerando-se a semeadura efetuada na época convencional $\left(S_{1}\right)$, nota-se que após a colheita (E1), as sementes já apresentavam níveis consideráveis de sementes infectadas por Aspergillus spp (Figura 13) e por Penicillium spp (Figura 15), mas não por A. niger (Figura 14).

Cabe esclarecer, que a partir da colheita até a retirada das amostras para condução da primeira época de avaliação da qualidade fisiológica e sanitária das sementes passaram-se em torno de 30 dias, devido ao tempo gasto com as avaliações de características agronômicas realizadas nas plantas após a colheita, debulha manual das vagens e determinação da produção. Observando-se as Figuras 5 e 6 , constata-se que esse período, situado entre final de março e abril; caracterizou-se por umidade relativa e temperatura relativamente elevadas, favoráveis ao desenvolvimento destes fungos, segundo CHRISTENSEN (1973). 


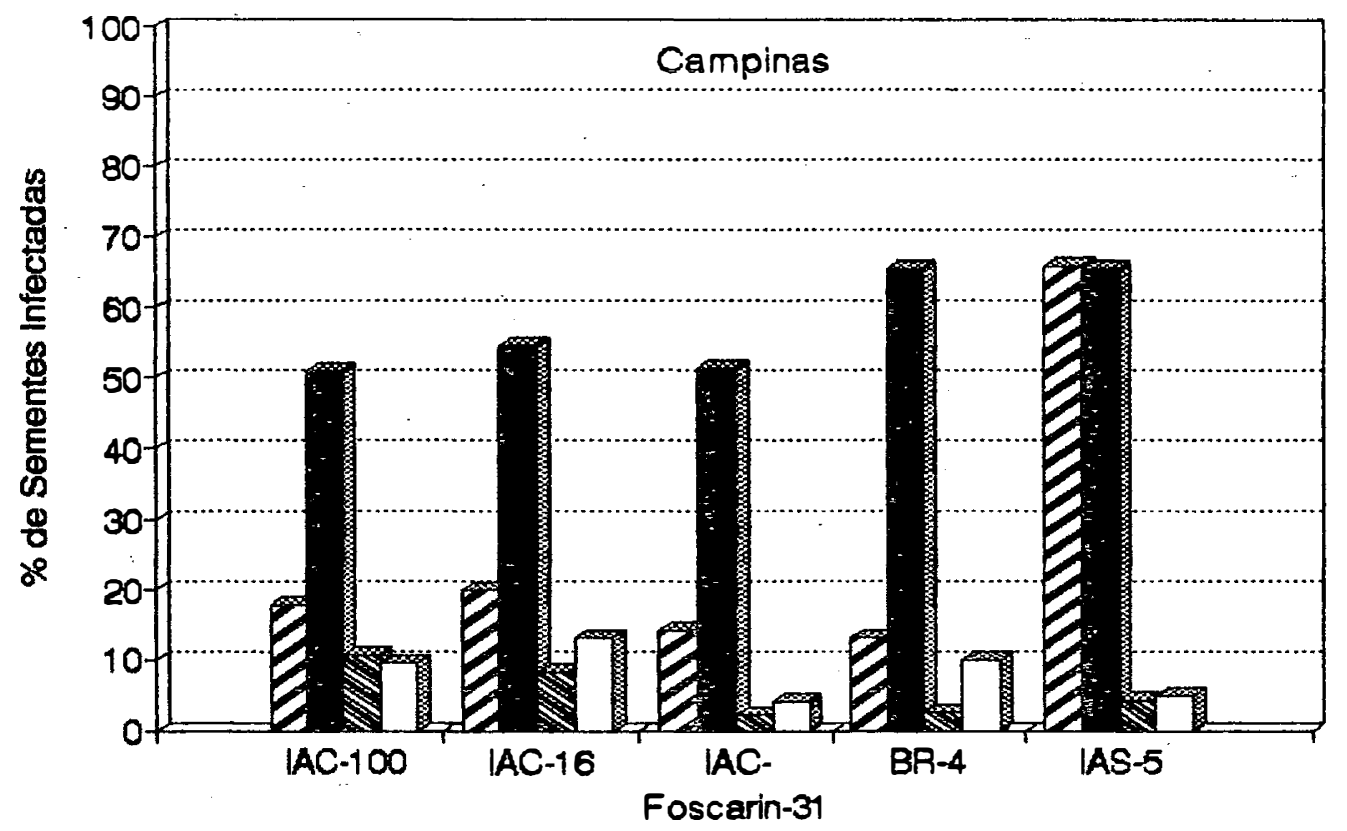

QS1E1 S S1E2 S2E1 $\square$ S2E2

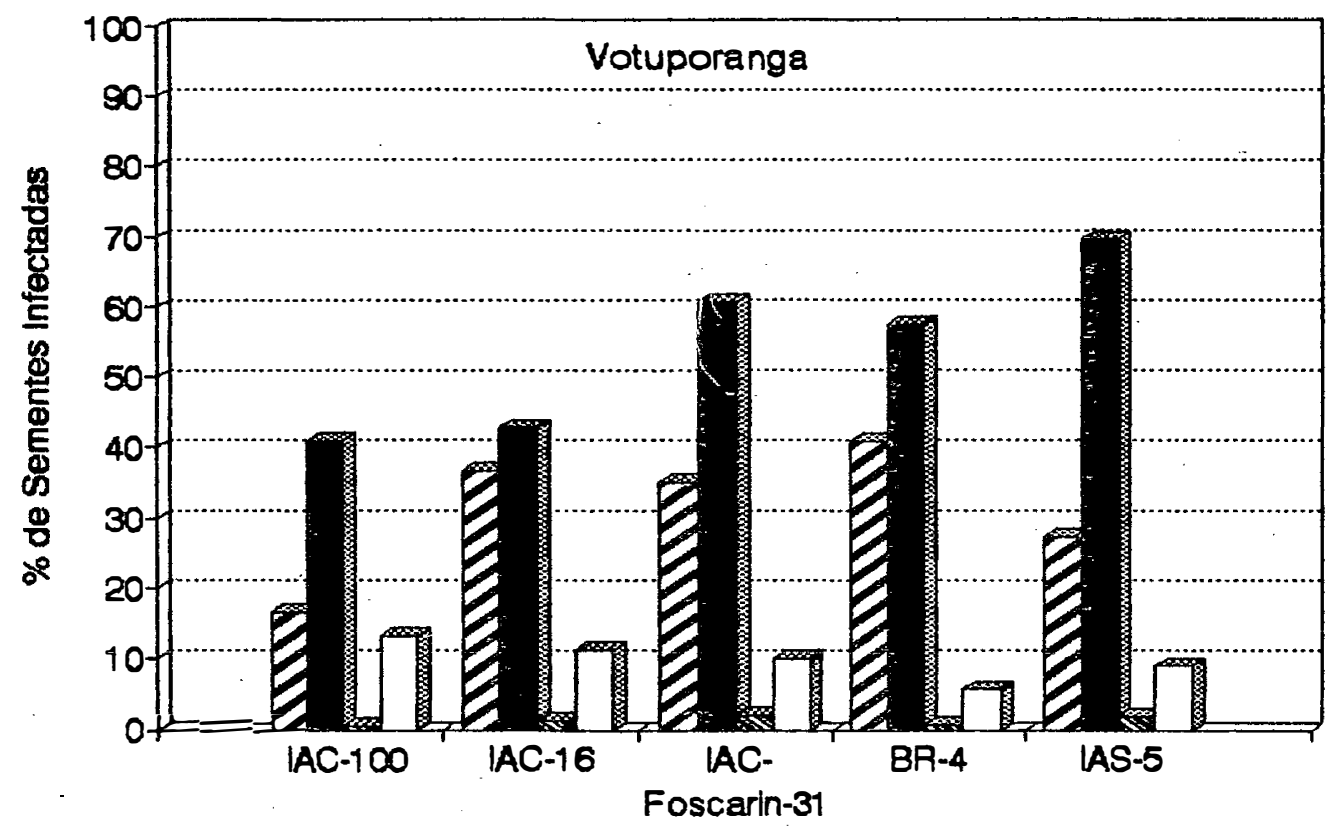

EST1-E1 S S1-E2 S2E1 $\square$ S2-E2

Figura 13. Valores médios (z) de sementes infectadas por Aspergillus spip, obtidos em função de épocas de semeadura e de épocas de teste, 1990. 


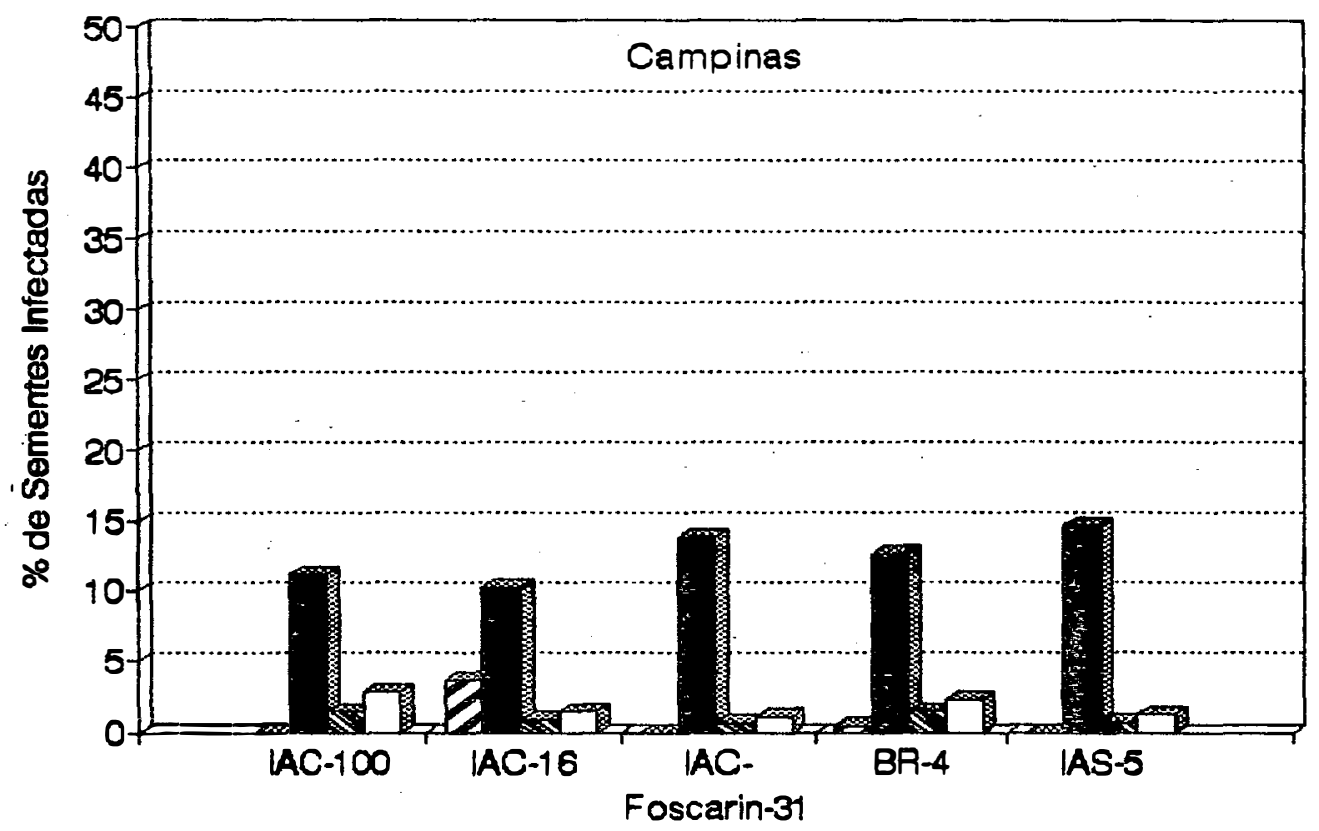

QS1E1 S1E2 S2E1 $\square$ S2E2

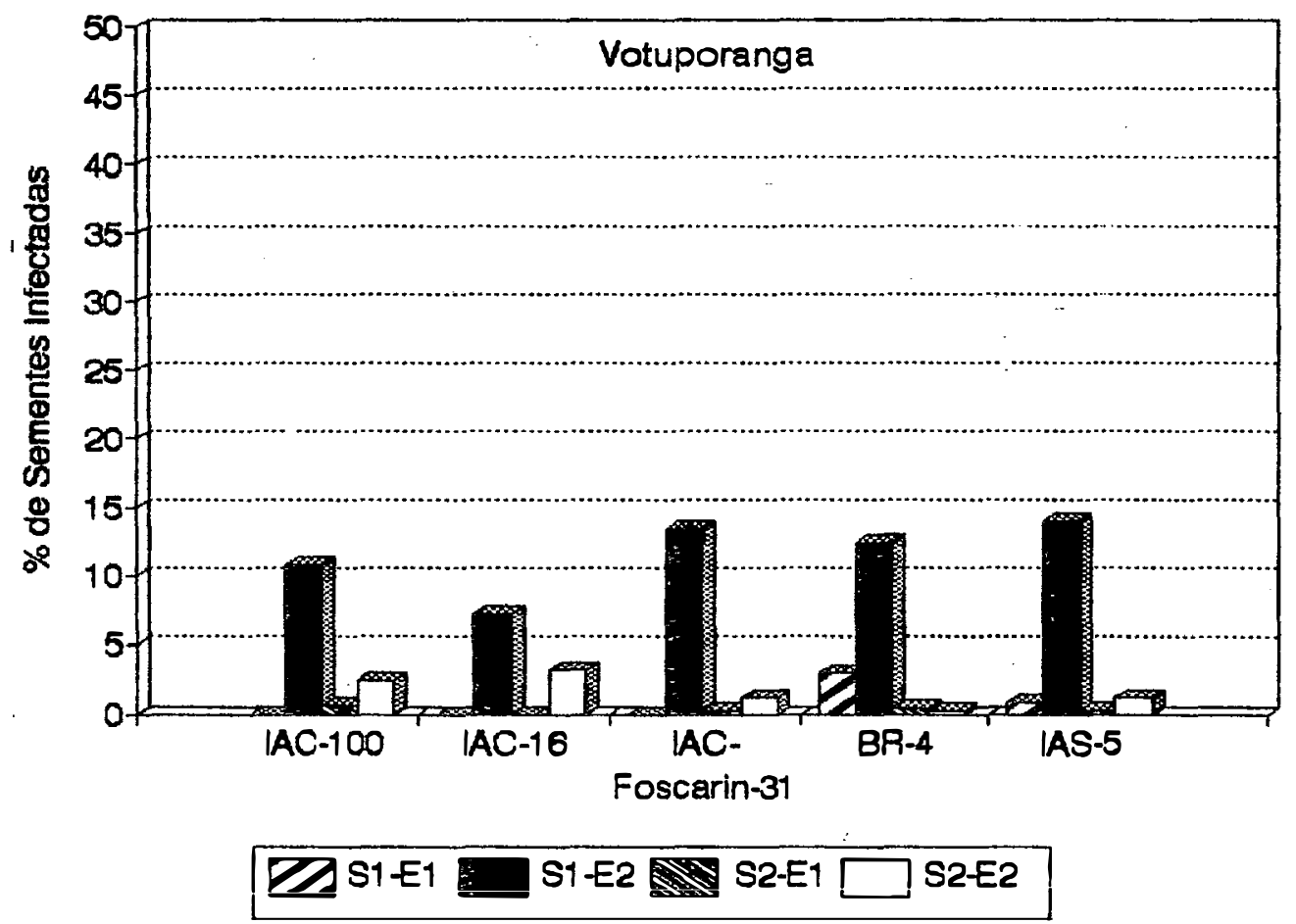

Figura 14. Valores médios $(\%)$ de sementes infectadas por Aspergillus niger, obtidos em função de épocas de semeadura e de épocas de teste, 1990. 


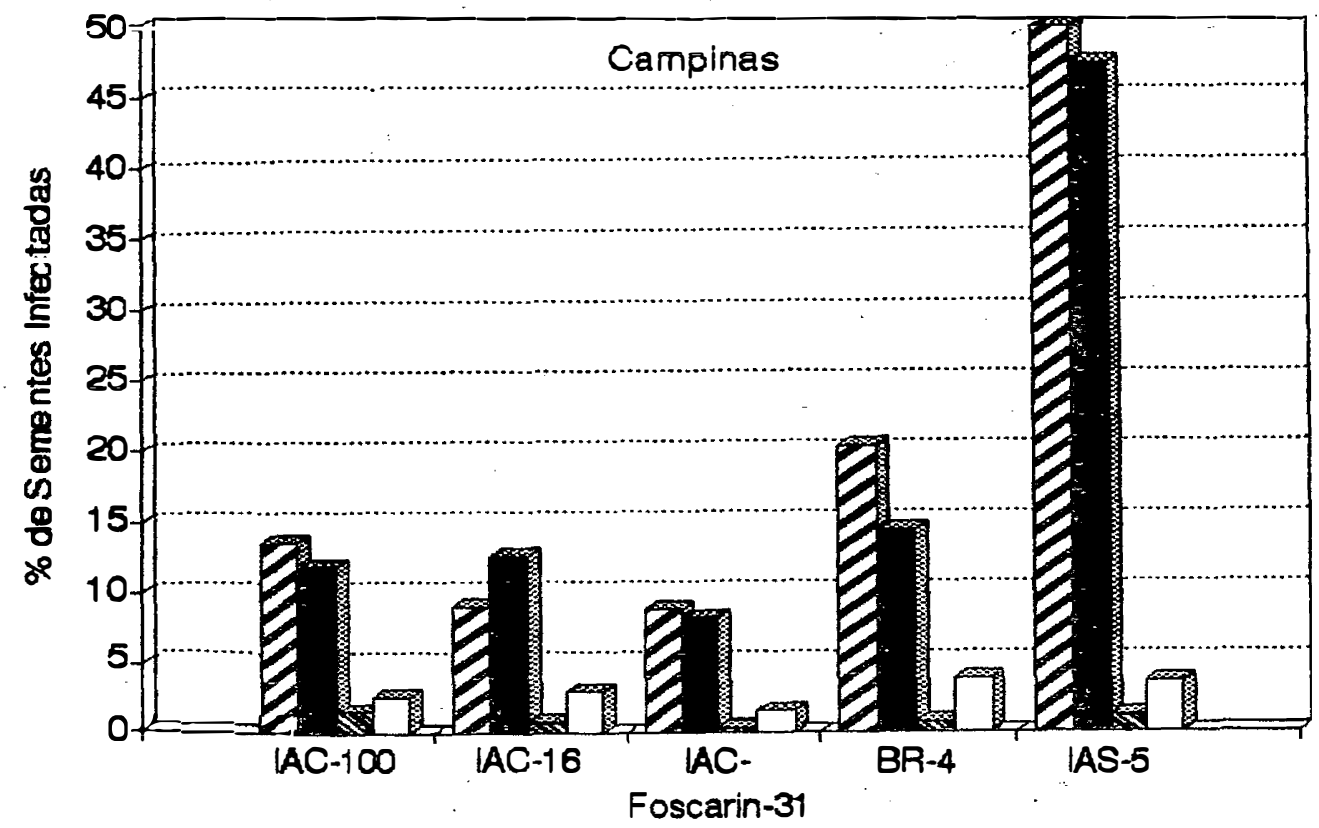

QS1E1 LS1E2 S2E1 $\square$ S2E2

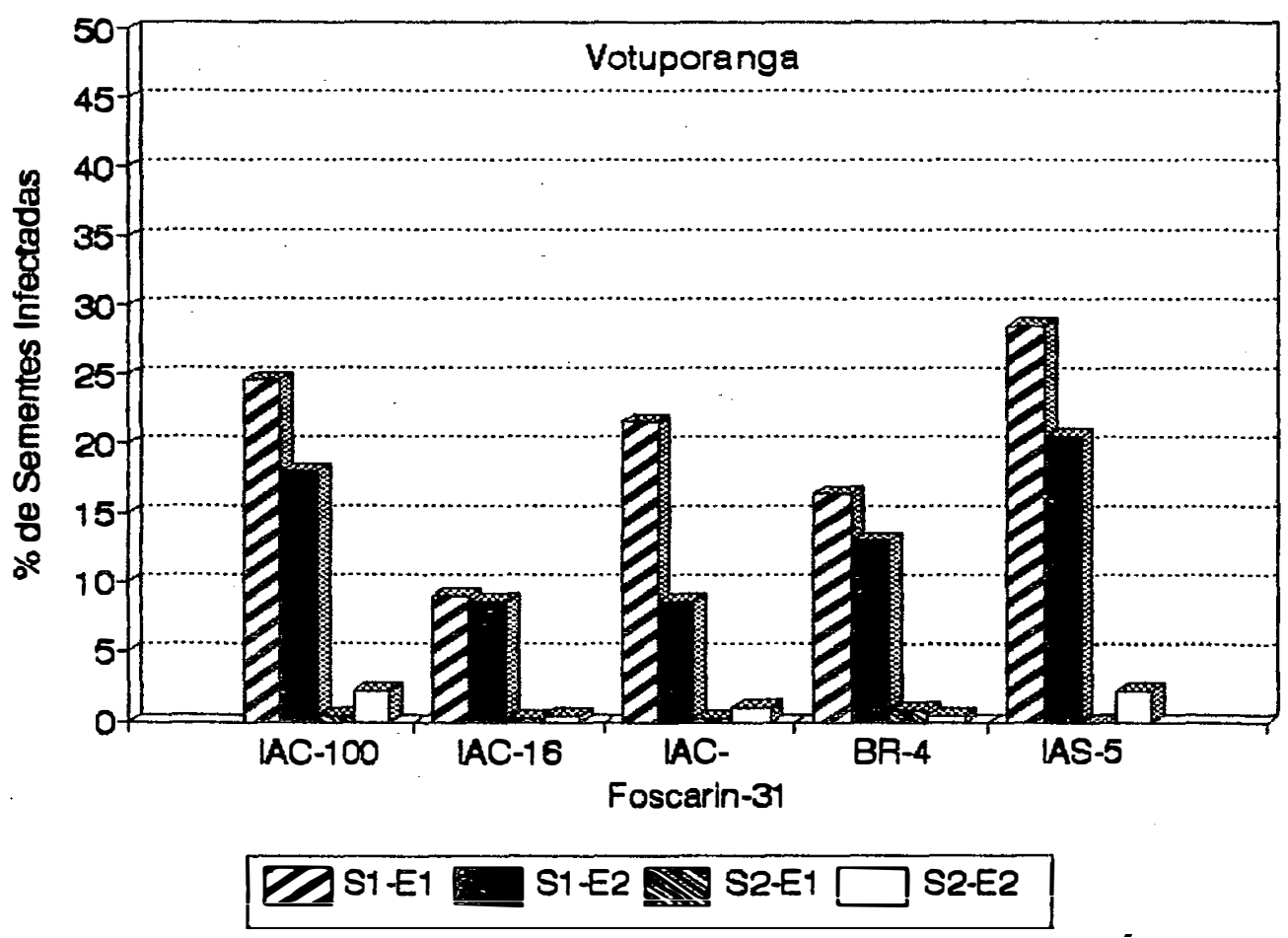

Figura 15. Valores médios $(8)$ de sementes infectadas por Penicillium spp, obtidos en função de épocas de semeadura e de épocas de teste, 1990. 
Ainda, de acordo com WETZEL (1987), estes microrganismos possuem elevado poder de propagação, e, embora presentes no campo em porcentagens baixíssimas, multiplicam-se em poucos dias, desde que encontrem condições de ambiente favoráveis.

Quando as sementes foram produzidas em Campinas em $\mathrm{S}_{1}$, O cultivar IAS-5 destacou-se pela mais elevada incidência de Aspergillus spp (Figura 13) e Penicillium spp (Figura 15) em comparação aos demais cultivares. Em Votuporanga, também foi o cultivar que apresentou maior incidência de Penicillium spp nas sementes.

Em $\mathrm{S}_{2}$, embora as amostras de sementes de soja também tenham sido retiradas para análise um mês após a colheita, observa-se que neste período, compreendido entre a colheita (início de julho) e a condução da primeira época de testes (agosto), as condições de clima foram bem mais secas e de temperaturas amenas (Figuras 5 e 6), desfavorecendo, para CHRISTENSEN (1973), o crescimento de fungos de armazenamento.

De fato, analisando-se as Figuras 13 e 15, respectivamente, constata-se menor incidência dos fungos Aspergillus spp e Penicillium spp nas sementes de todos os cultivares colhidas em $\mathrm{S}_{2}$ nos dois locais estudados em comparação a $S_{1}$, na avaliação efetuada após a colheita (E1) • 
A incidência de Aspergillus niger (Figura 14) foi muito baixa nas sementes de todos os cultivares obtidas em Campinas e Votuporanga em $S_{2}$ na avaliação das sementes efetuada em El.

Analisando-se a Figura 6, verifica-se que durante todo o período de armazenamento das sementes de soja colhidas em $S_{1}$ ou $S_{2}$, a umidade relativa do ar média foi superior a 65\%, considerada por CHRISTENSEN (1973) como - limite mínimo para o desenvolvimento de Aspergillus spp, principais fungos prejudiciais às sementes de soja armazenadas, de acordo com HENNING (1987) •

As temperaturas (Figura 5) também foram superiores à mínima exigida para crescimento destes fungos, situando-se em torno da ótima em dois períodos: durante o. mês de abril e do mês de outubro em diante.

Assim, observando--se as Figuras 13 e 14 confirma-se $O$ acentuado crescimento desses fungos nas sementes colhidas em $S_{1}$ até a época em que seria realizada a semeadura da safra seguinte (E2).

Quanto a Penicilium spp, apesar de as temperaturas (Figura 5) não terem sido limitantes à atividade deste fungo durante o armazenamento, a umidade relativa do ar média raramente chegou a 85\%, valor considerado mínimo para crescimento de Penicillium spp, segundo CRHISTENSEN (1973). Desta forma, observou-se tendência a queda quanto à incidência deste fungo nas sementes de soja obtidas em $\mathrm{S}_{1}$, quando analisadas em E2 em comparação à E1. 
As sementes colhidas em $S_{i}$ permaneceram armazenadas durante período mais curto até a época em que seria realizado o plantio da safra seguinte (E2) em comparação às obtidas em $S_{1}$ (Figuras 5 e 6 ), de forma que os fungos de armazenamento, presentes em níveis mais baixos nas sementes obtidas em $S_{2}$ na ocasião da colheita, tiveram menor período disponível para se desenvolverem nas sementes em comparação às colhidas em $\mathrm{S}_{1}$.

Assim, quando foi efetuada a análise das sementes em E2, comparando-se as duas semeaduras $\left(S_{1}\right.$ e $\left.S_{2}\right)$, para os dois locais estudados, nota-se que as sementes obtidas em $\mathrm{S}_{2}$ apresentaram níveis acentuadamente inferiores de sementes infectadas por fungos de armazenamento (Figuras 13, 14 e 15) em comparação às colhidas em $S_{1}$. Estes fiungos, de acordo com CHRISTENSEN (1973) invadem preferencialmente - embrião das sementes, reduzindo-lhes 0 potencial de germinação.

Outros fungos, embora considerados saprófitas por HENNING (1987) também foram incluídos nesta pesquisa por terem apresentado elevada incidência sobre as sementes, como Rhyzopus spp (Figura 16) e Cladosporium spp (Figura 17), ou por terem ocorrido, preferencialmente, sob condições de clima quente e úmido durante a maturação das sementes, como Alternaria spp (Figura 18) e Phoma spp (Figura 19). 


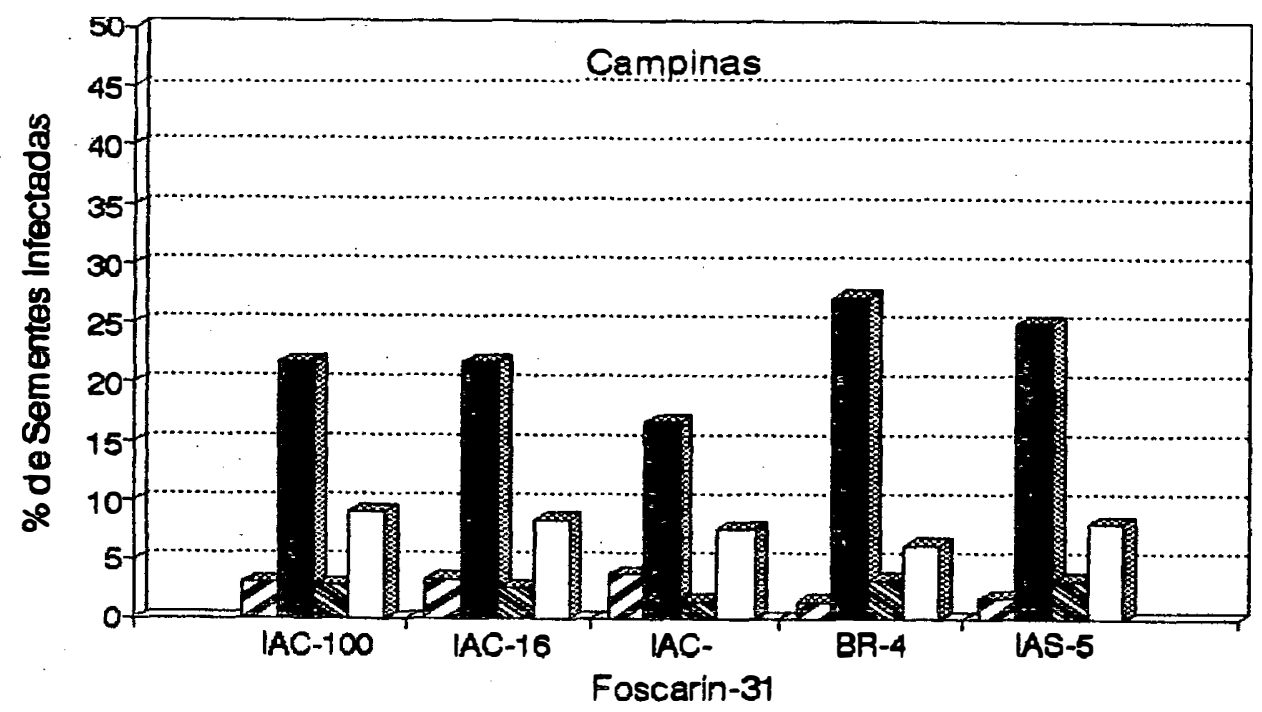

QS1E1 S1E2 S2E1 $\square$ S2E2

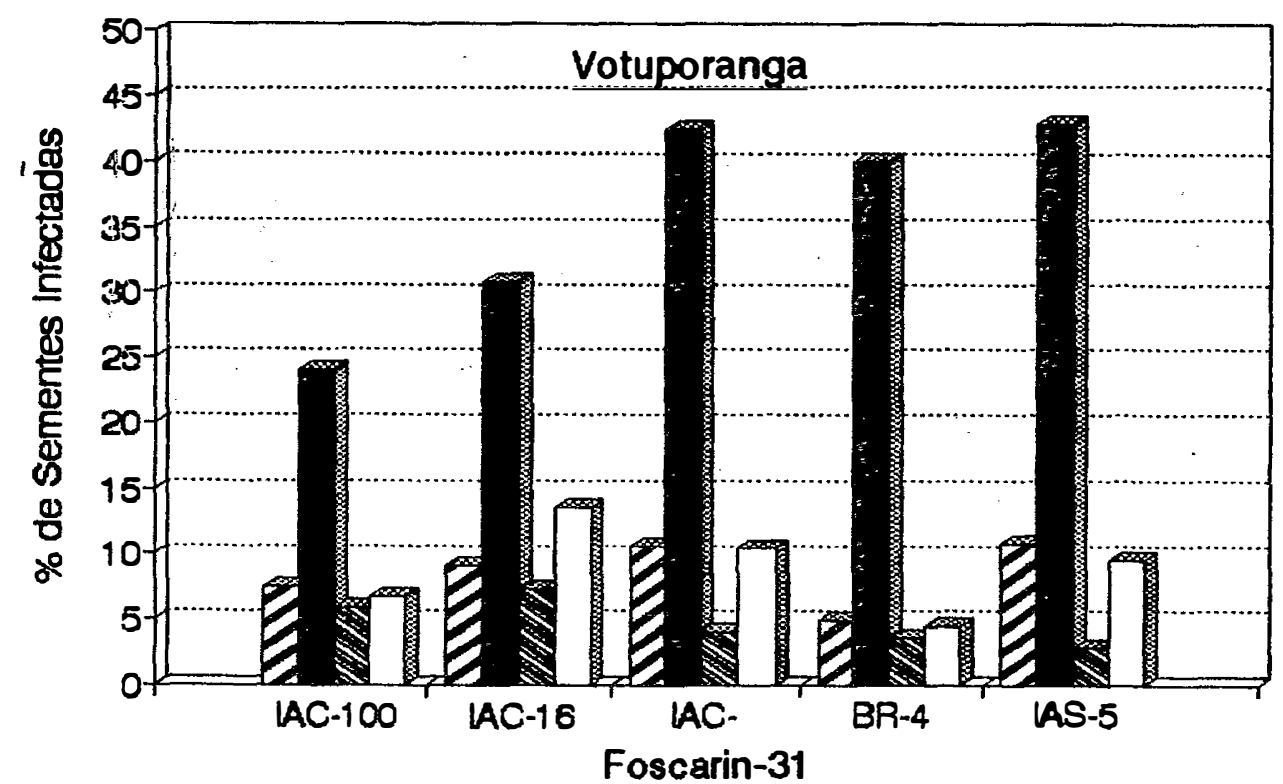

S1-E1 S1-E2 S2-E1 $\square$ S2-E2

Figura 16. Valores médios $(8)$ de sementes infectadas por Rhizopus spp, obtidos en função de épocas de semeadura e de épocas de teste, 1990. 


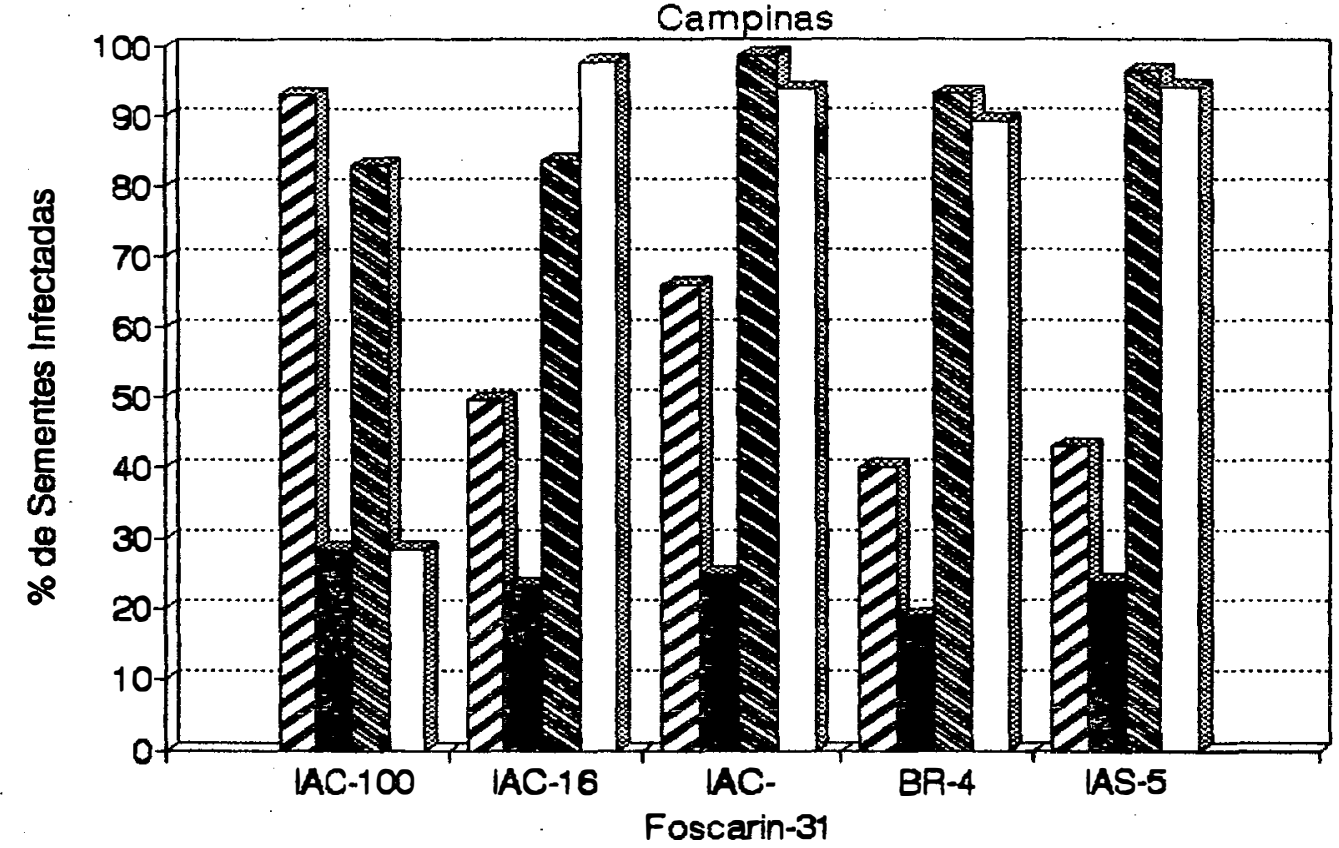

QAS1E1 S S1E2 NS S2E1 $\square$ S2E2

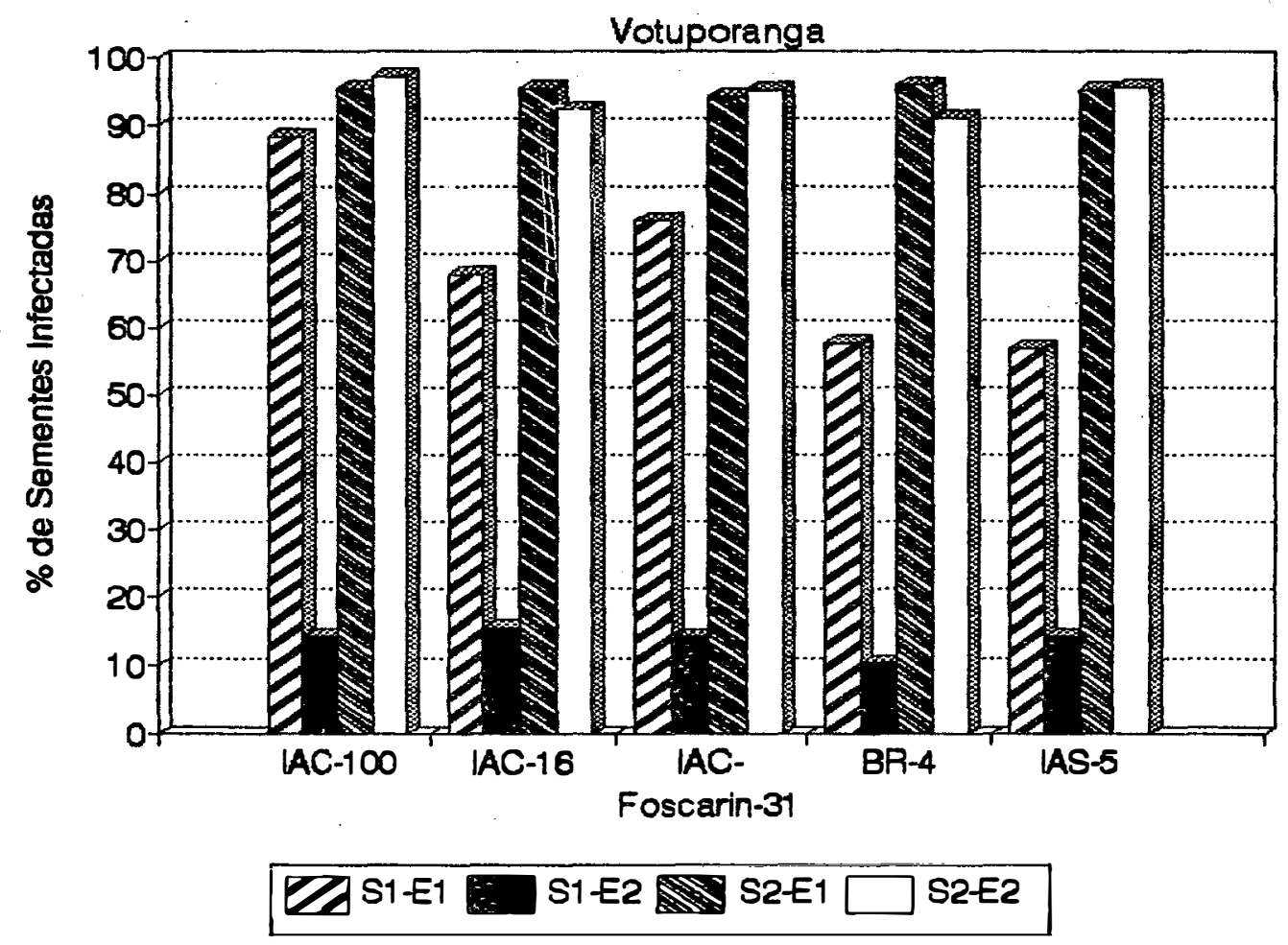

Figura 17. Valores médios (z) de sementes infectadas por Claudosporium spp, obtidos em função de épocas de semeadura e de épocas de teste, 1990. 


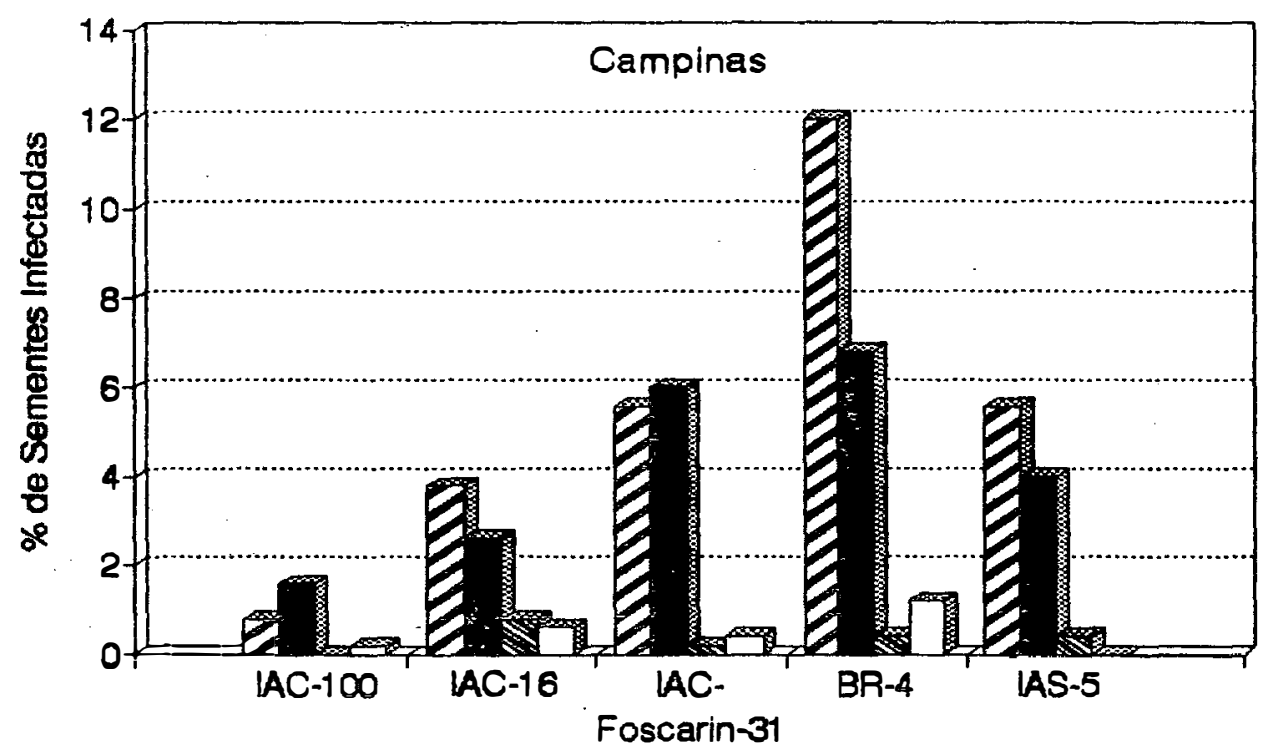

S1E1 S1-E2 S2-E1 $\square$ S2E2

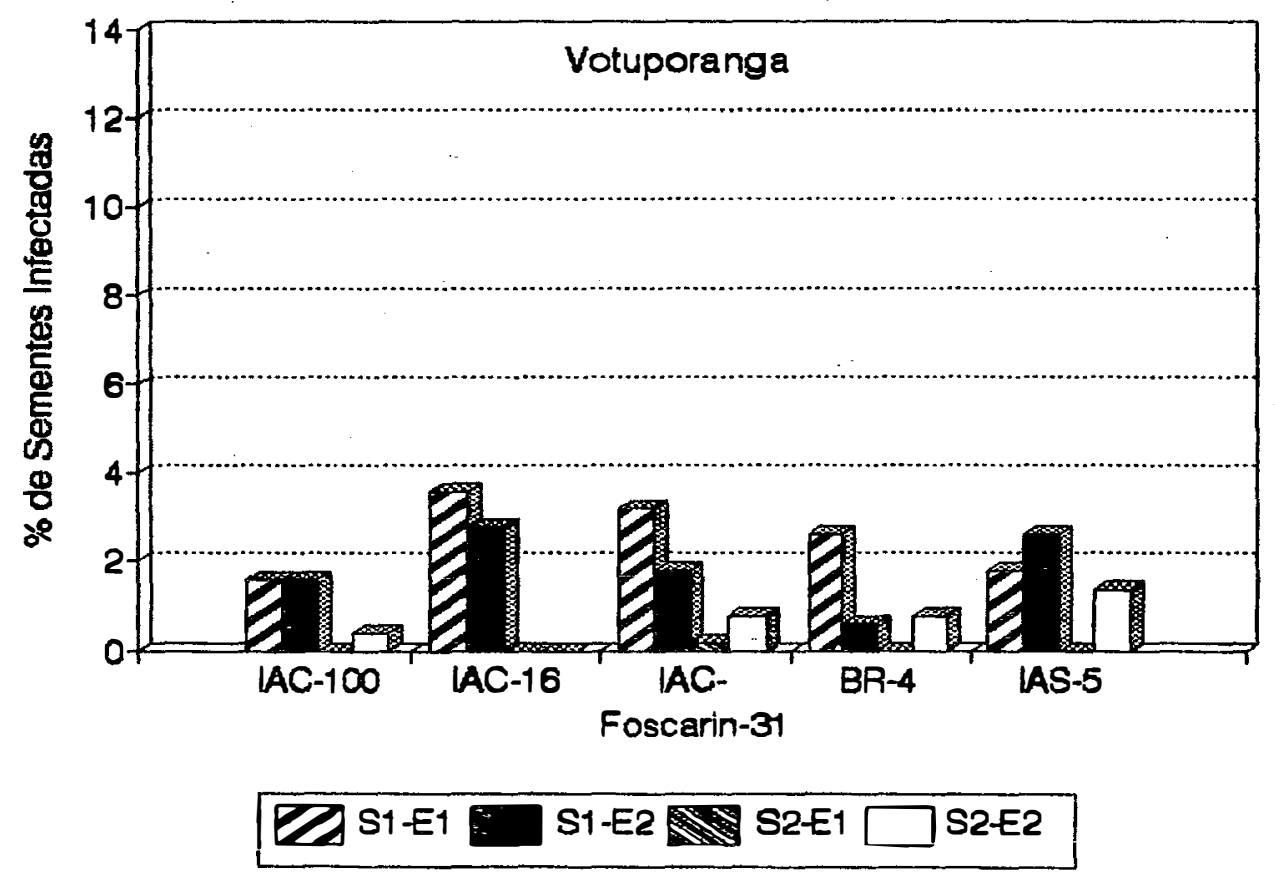

Figura 18. Valores médios $(z)$ de sementes infectadas por Alternaria spp, obtidos em função de épocas de semeaduxa e de épocas de teste, 1990. 


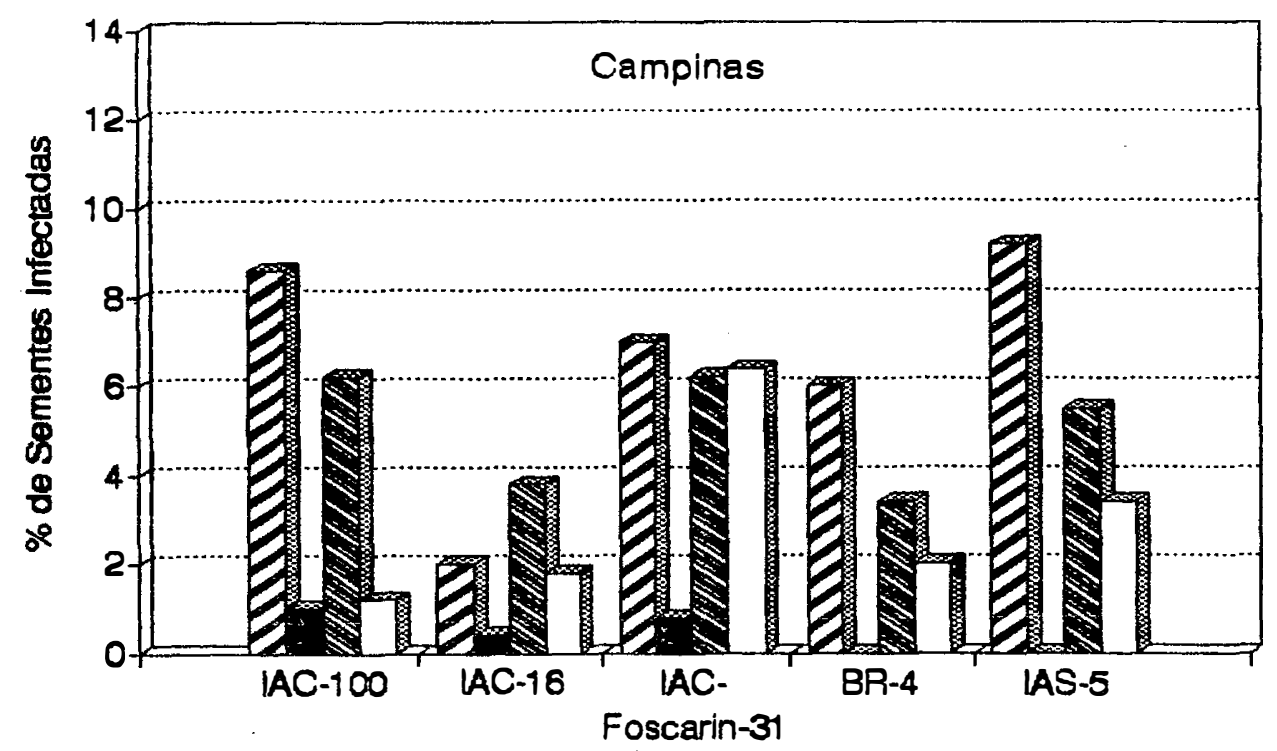

ZS1-E1 $\square$ S1E2 S2-E1 $\square$ S2-E2

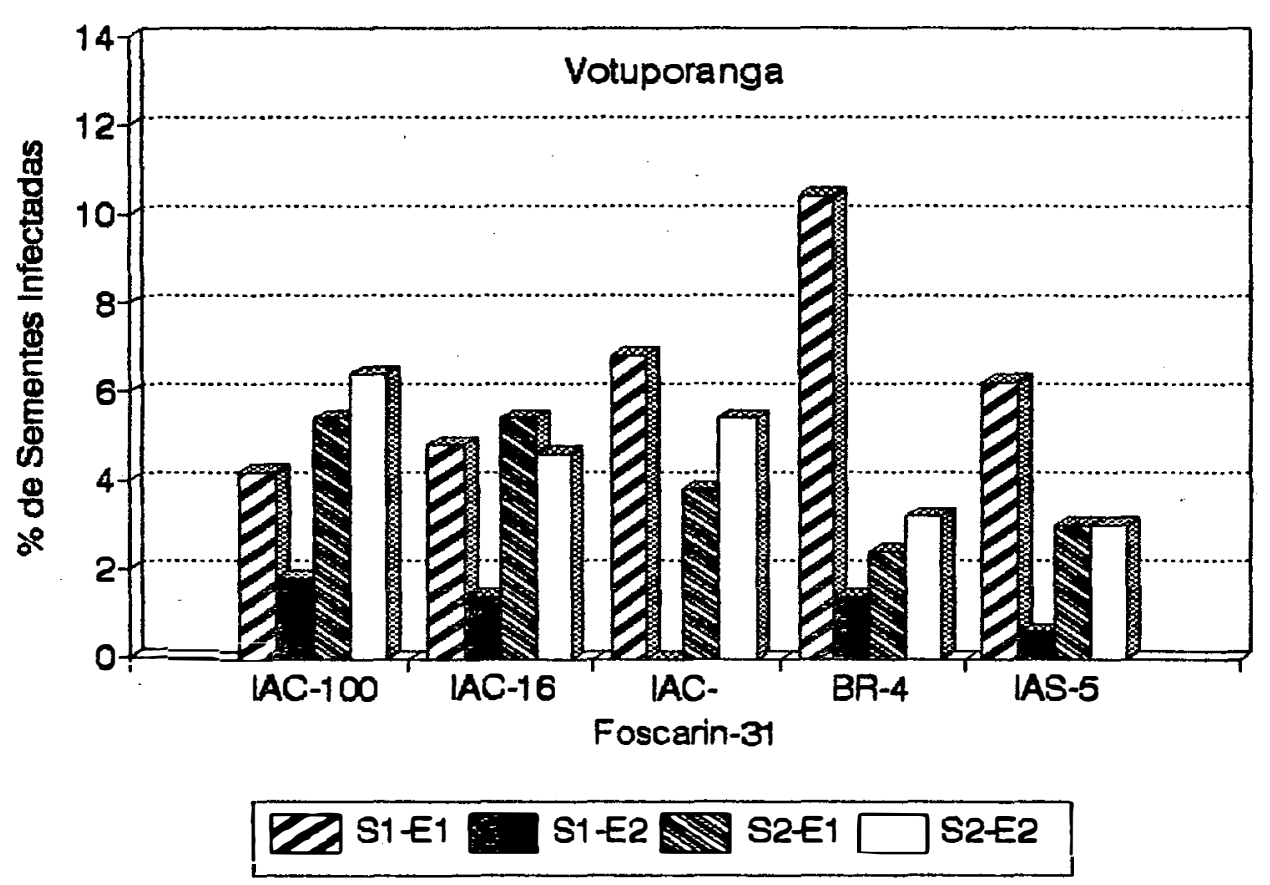

Figura 19. Valores médios (z) de sementes infectadas por Phoma spp, obtidos em função de épocas de semeadura e de épocas de teste, 1990. 
Analisando-se a Figura 16, constata-se que os fungos Rhyzopus spp comportaram-se de modo semelhante aos fungos de armazenamento, principalmente os do gênero Aspergillus (Figura 13 e 14), destacando-se a sua capacidade de crescimento intenso durante o armazenamento das sementes, de forma que, por ocasião do plantio da safra seguinte (E2), as sementes obtidas em $S_{1}$ tanto em Campinas quanto em Votuporanga apresentaram níveis de incidência deste fungo acentuadamente superiores em comparação às produzidas em $\mathrm{S}_{2}$.

Nota-se ainda, comparando-se as sementes obtidas nos dois locais em $S_{1}$, que a incidência desses fungos foram maiores nas sementes colhidas em Votuporanga e também cresceram mais sobre estas sementes durante o armazenamento.

Este fato, da mesma forma que se observou para Fusarium spp, pode estar associado à pior qualidade fisiológica dessas sementes em comparação às obtidas em Campinas. O fungo Cladosporium spp (Figura 17) apresentou elevado nível de incidência sobre as sementes de soja produzidas em $S_{1}$ nos dois locais estudados quando a análise de sanidade foi efetuada após a colheita (E1); do mesmo modo que os outros fungos de campo, sofreu queda durante o armazenamento até (E2). 
Quando as sementes foram produzidas em $\mathrm{S}_{2}$, apresentando, de modo geral, melhor qualidade fisiológica acompanhada por menor incidência de fungos patogênicos, a incidência de Cladosporium spp sobre as sementes foi maior. o menor período de armazenamento destas sementes em comparação aos das sementes produzidas em $S_{1}$ não foi suficiente para reduzir consideravelmente a incidência desses fungos sobre as sementes de soja. Desta forma em E2, as sementes produzidas em $\mathrm{S}_{2}$ apresentaram sementes com níveis de ocorrência de Cladosporium spp acentuadamente superiores aos das obtidas em $\mathrm{S}_{1}$.

Embora tenham sido incluídos como saprófitas por HENNING (1987), os fungos Alternaria spp, de acordo com KUNWAR et al. (1986), têm sido associados às condições úmidas do ambiente. Este fato também foi constatado na presente pesquisa, como mostra a Figura 18.

Mesmo com incidência inferior a de outros fungos de campo, como Phomopsis sojae ou Fusarium spp, foi possível verificar a influência do clima na ocorrência de Alternaria spp. Assim, nota-se que à semelhança de Phomopsis sojae e Colletotrichum dematium, esses fungos ocorreram em $\mathrm{S}_{1}$ com predominância nas sementes obtidas em Campinas, para os cultivares 'IAC-Foscarin-31', 'BR-4' e 'IAS-5', devido ao clima mais úmido observado neste local. Em $\mathrm{S}_{2}$, quando o clima foi seco no período que coincidiu com a maturação das sementes, os níveis de infecção por Alternaria spp foram bem reduzidos nas sementes produzidas em Campinas e praticamente nulos nas colhidas em Votuporanga. 
Por outro lado, o armazenamento, de modo geral, não evidenciou queda significativa da incidência destes fungos nas sementes de soja obtidas em $S_{1}$ ou $S_{2}$; na ocasião do plantio da safra seguinte (E2), as sementes produzidas em $\mathrm{S}_{1}$ continuaram apresentando niveis superiores de Alternaria spp em relação às obtidas em $S_{2}$.

A incidência de Phoma spp nas sementes de soja, praticamente, não superou $10 \%$ (Figura 19) em Campinas e Votuporanga.

À semelhança dos demais fungos de campo, em $\mathrm{S}_{1}$ foram obtidos níveis superiores de sementes contaminadas por esses fungos, em comparação a $S_{2}$, com exceção do cultivar IAC-100 em Votuporanga e 'IAC-16' nos dois locais estudados.

Durante o armazenamento, o comportamento desses fungos também acompanhou o dos principais patógenos de campo observados nestas sementes, de forma que, o período mais prolongado de armazenamento das sementes obtidas em $S_{1}$ resultou em acentuada queda ou até eliminação da incidência de Phoma spp nas sementes de soja. Por outro lado, o período mais curto de armazenamento das sementes obtidas em $\mathrm{S}_{2}$ não alterou consideravelmente a incidência desses fungos sobre as sementes de soja obtidas nesta época. Assim, em E2, as sementes obtidas em $\mathrm{S}_{2}$ apresentaram níveis superiores de sementes contaminadas por Phoma spp em comparação às produzidas em $\mathrm{S}_{1}$. 


\subsubsection{Sementes com mancha café}

Analisando-se a Tabela 28, constata-se que, de modo geral, as porcentagens de sementes com mancha café foram baixas, atendendo aos padrões de sementes básicas e certificadas (SÃO PAULO, S.A.A., 1993). A única exceção foi quanto às sementes do cultivar IAC-16 produzidas em Campinas na semeadura tardia $\left(S_{2}\right)$. Entretanto, durante a avaliação deste parâmetro para este cultivar, observou-se que as manchas eram muito pequenas, restringindo-se a um ligeiro derramamento do hilo, às vezes, de difícil visualização.

Apesar dos valores muito baixos das médias obtidas para este parâmetro, verificou-se tendência de maior ocorrência de sementes com mancha café na semeadura tardia e de modo mais nitido em Campinas do que em Votuporanga, com exceção do cultivar IAC-100 que praticamente não apresentou sementes manchadas em $\mathrm{S}_{2}$.

\subsection{Produção de Sementes Viáveis}

Na Tabela 29 encontram-se os níveis de significância relativos aos valores de F obtidos na análise de variância dos dados referentes à este parâmetro. 
Tabela 28. Sementes com mancha café: valores médios (\%) obtidos para cada cultivar de soja, em função de épocas e locais de semeadura.

\begin{tabular}{ccccc}
\hline Cultivares & $\begin{array}{c}\text { Épocas de } \\
\text { Semeadura }\end{array}$ & Campinas & Votuporanga & Médias \\
\hline$S_{1}$ & 0,14 & 0,00 & 0,07
\end{tabular}

IAC-100

$\begin{array}{ccccc} & S_{2} & 0,02 & 0,00 & 0,01 \\ \text { Médias } & & 0,08 & 0,00 & \\ & S_{1} & 0,02 & 0,02 & 0,02\end{array}$

IAC-16

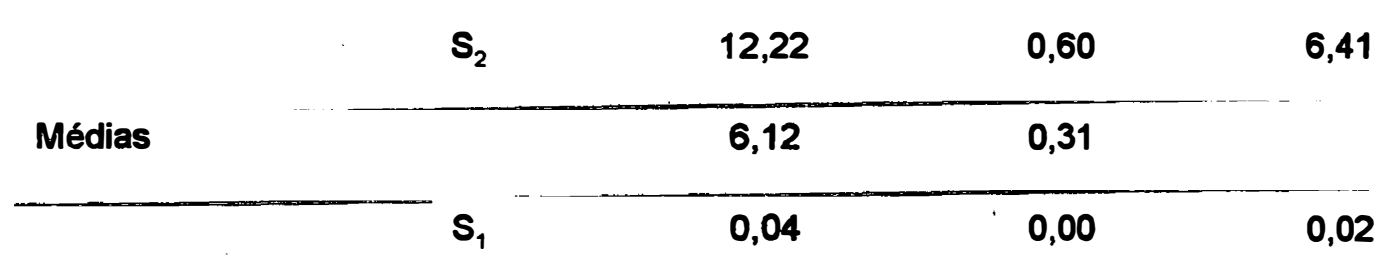

IAC-Foscarin-31

\begin{tabular}{|c|c|c|c|c|}
\hline & $S_{2}$ & 2,48 & 0,06 & 1,27 \\
\hline Médias & & 1,26 & 0,03 & \\
\hline & $S_{1}$ & 0,00 & 0,00 & 0,00 \\
\hline
\end{tabular}

$B R-4$

\begin{tabular}{ccccc} 
& $s_{2}$ & 0,24 & 0,02 & 0,13 \\
\hline Médias & & 0,12 & 0,01 & \\
\hline & $S_{1}$ & 0,02 & 0,00 & 0,01
\end{tabular}

IAS-5

$\begin{array}{llll}S_{2} & 0,60 & 0,04 & 0,32\end{array}$


Tabela 29. Níveis de significância relativos aos valores de F obtidos nas análises de variância dos dados referentes à produção de sementes viáveis.

\begin{tabular}{|c|c|c|c|}
\hline Cultivares & $\begin{array}{l}\text { Causas de } \\
\text { Variaçăo }\end{array}$ & Após colheita (E1) & Novembro de 1990 (E2) \\
\hline & Local (L) & $* *$ & $* *$ \\
\hline \multirow[t]{3}{*}{ IAC-100 } & Semeadura (S) & ** & ** \\
\hline & Interação (LXS) & ns & ns \\
\hline & Local (L) & ** & ** \\
\hline \multirow[t]{3}{*}{ IAC-16 } & Semeadura (S) & $\star$ & ns \\
\hline & Interação (LXS) & ns & ns \\
\hline & Local (L) & ns & * \\
\hline \multirow[t]{3}{*}{ IAC-Foscarin-31 } & Semeadura (S) & $* \star$ & $* *$ \\
\hline & Interação (LXS) & ns & * \\
\hline & Local (L) & * & * \\
\hline \multirow[t]{3}{*}{$B R-4$} & Semeadura (S) & * & ns \\
\hline & Interação (LXS) & * & * \\
\hline & Local (L) & ** & ** \\
\hline \multirow[t]{2}{*}{ IAS-5 } & Semeadura (S) & * & ns \\
\hline & interação (LxS) & $=$ & ns \\
\hline
\end{tabular}

ns não significativo

* significativo ao nível de 5\% de probabilidade ** significativo ao nível de $1 \%$ de probabilidade 
Observando-se a Tabela 30, verifica-se que após a colheita $\left(E_{1}\right)$, a produção de sementes viáveis foi superior em Campinas em comparação à Votuporanga na época de semeadura convencional $\left(S_{1}\right)$ para os cultivares 'IAC100', 'IAC-16' e 'IAS-5'. Os cultivares 'IAC-Foscarin-31' e 'BR-4' não apresentaram diferenças significativas quanto às sementes viáveis produzidas nos dois locais estudados nesta época.

Porém, após o armazenamento durante 8 meses (E2), nota-se que a quantidade de sementes viáveis obtidas em Campinas em $S_{1}$, passou a superar à colhida em Votuporanga para todos os cultivares, com exceção do IAC Foscarin-31.

Considerando-se $S_{2}$, a produção de sementes viáveis , com exceção para o IAC-Foscarin-31, foi superior em Campinas em relação à Votuporanga nas duas avaliações realizadas (E1 e E2) devido exclusivamente à maior produção obtida naquele local.

É interessante observar, que a quantidade de sementes viáveis produzidas nos dois locais em $S_{2}$ aumentou ligeiramente para todos os cultivares após o armazenamento (E2). Isto também pode ser considerado um reflexo da excelente qualidade fisiológica das sementes obtidas nessa época, caracterizada por menores níveis de deterioração causada por temperatura e umidade elevadas, associados à menor incidência de fungos de campo e de armazenamento, de um modo geral, em comparação às sementes colhidas em $\mathrm{S}_{1}$. 
Tabela 30. Produção de sementes viáveis: valores médios (Kg/ha) obtidos para cada cultivar de soja, em função de épocas e locais de semeadura.

\begin{tabular}{|c|c|c|c|c|c|c|c|}
\hline \multirow[t]{2}{*}{ Cultivares } & \multirow{2}{*}{$\begin{array}{l}\text { Epocas de } \\
\text { Semeadura }\end{array}$} & \multicolumn{3}{|c|}{ Após colheita (E1) } & \multicolumn{3}{|c|}{ Novembro de 1990 (E2) } \\
\hline & & Campinas & Votuporanga & Médias & Campinas & Votuporanga & Médias \\
\hline & s1 & 2835,8 & 1817,6 & 2326,7 A & 2685,9 & 1423,7 & $2054,8 \mathrm{~A}$ \\
\hline \multicolumn{8}{|l|}{ IAC-100 } \\
\hline & $\mathbf{s 2}$ & 1909,1 & 957,2 & $1433,2 \mathrm{~B}$ & 2005,6 & 961,4 & $1483,5 \mathrm{~B}$ \\
\hline Médias & & 2372,5 a & $1387,4 \mathrm{~b}$ & & 2345,8 a & $1.192,6 \mathrm{~b}$ & \\
\hline C.V. \% & & & 22,18 & & & 21,12 & \\
\hline & s1 & 2241,2 & 1678,7 & $1960,0 \mathrm{~A}$ & 2343,2 & 1198,8 & $1771,0 \mathrm{~A}$ \\
\hline \multicolumn{8}{|l|}{ IAC-16 } \\
\hline & s2 & 1810,5 & 1028,9 & $1419,7 \mathrm{~B}$ & 1816,9 & 1034,5 & $1425,7 \mathrm{~A}$ \\
\hline Médias & & 2025,9 a & $1353,8 \mathrm{~b}$ & & 2080,1 a & $1116,7 \mathrm{~b}$ & \\
\hline C.V. \% & & & 28,95 & & & 29,98 & \\
\hline \multirow{2}{*}{$\begin{array}{l}\text { IAC- } \\
\text { Foscarin-31 }\end{array}$} & s1 & 2174,0 & 1958,2 & $2065,1 A$ & $2123,9 \mathrm{Aa}$ & $1736,2 \mathrm{Aa}$ & 1930,1 \\
\hline & $\mathbf{S 2}$ & 1583,9 & 1166,3 & $1375,1 B$ & $1617,0 \mathrm{Aa}$ & $1210,2 \mathrm{Ba}$ & 1413,6 \\
\hline Médias: & & 1879,0 a & 1561,3 a & & 1870,5 & 1473,2 & \\
\hline C.V. \% & & & 25,18 & & & 22,59 & \\
\hline & s1 & $2246,4 \mathrm{Aa}$ & $2272,3 \mathrm{Aa}$ & 2259,4 & 2244,7 & 1789,4 & $2.017,1 \mathrm{~A}$ \\
\hline \multicolumn{8}{|l|}{$B R-4$} \\
\hline & S2 & $2259,5 \mathrm{Aa}$ & $1557,6 \mathrm{Bb}$ & 1908,6 & 2282,6 & 1590,7 & $1.936,7 \mathrm{~A}$ \\
\hline Médias & & 2253,00 & 1915,0 & & 2263,7 a & $1690,1 \mathrm{~b}$ & \\
\hline C.V. \% & & & 15,32 & & & 12,48 & \\
\hline & s1 & $2531,2 \mathrm{Aa}$ & $1659,0 \mathrm{Ab}$ & 2010,1 & 2140,4 & 1192,3 & $1.666,4 \mathrm{~A}$ \\
\hline \multicolumn{8}{|l|}{ IAS-5 } \\
\hline & s2 & $1.876,2 \mathrm{Ba}$ & $1319,3 \mathrm{Ab}$ & 1597,8 & 1905,1 & 1335,0 & $1.620,1 \mathrm{~A}$ \\
\hline Médias & & 2118,7 & 1489,2 & & 2022,8 a & $1263,7 \mathrm{~b}$ & \\
\hline C.V. \% & & & 17,32 & & & 23,33 & \\
\hline
\end{tabular}

* Para cada cultivar, as médias da mesma coluna seguidas pela mesma letra maiúscula ou da mesma linha seguidas pela mesma letra minúscula não diferiram entre si, ao nível de 5\% de probabilidade, pelo testes de Tukey. 
Comparando-se as épocas de semeadura efetuadas em Campinas na avaliação realizada após a colheita (E1), constatou-se que a produção de sementes viáveis foi superior na época convencional $\left(S_{1}\right)$. o cultivar BR-4 foi o único que não apresentou diferença significativa entre as quantidades de sementes viáveis produzidas nas duas semeaduras.

Na avaliação conduzida após o armazenamento (E2), os maiores valores de germinação verificados para as sementes produzidas em $\mathrm{S}_{2}$ compensaram as maiores produtividades observadas em $S_{1}$, de forma que, diferenças entre as quantidades de sementes viáveis obtidas em $S_{1}$ e $S_{2}$ após a colheita (E1) tornaram-se não significativas, com exceção apenas do cultivar IAC-100.

Comparando-se as semeaduras realizadas em Votuporanga, verificâ-se que a produção de sementes viáveis foi superior para quase todos os cultivares em $S_{1}$, quando a avaliação da qualidade das sementes foi conduzida após a colheita (E1); embora o potencial de germinação das sementes tenha sido, de modo geral, significativamente superior na semeadura tardia $\left(S_{2}\right)$, apenas o cultivar IAS-5 conseguiu compensar as produções significativamente superiores obtidas em $\mathrm{S}_{1}$.

Quando a avaliação da qualidade das sementes foi conduzida após o armazenamento (E2), a queda acentuada do potencial de germinação das sementes de todos os cultivares obtidas em $S_{1}$ resultou na redução das diferenças 
entre as quantidades de sementes viáveis produzidas em $\mathrm{S}_{1}$ e $\mathrm{S}_{2}$, de forma que, as médias obtidas para os cultivares 'IAC-16', 'BR-4' e 'IAS-5' não foram significativamente diferentes.

\subsection{Considerações Finais}

Considerando-se os resultados obtidos na presente pesquisa de um modo geral e comparando-se as duas regiões estudadas, constatou-se que as condições de clima e solo em que foram instalados os experimentos em Campinas foram mais favoráveis à produção de sementes viáveis, em relação às observadas em Votuporanga.

Quando a semeadura foi conduzida na época convencional $\left(S_{1}\right)$, as condições do ambiente em Campinas propiciaram a obtenção de maiores quantidades de sementes apresentando melhor qualidade fisiológica em comparação ao ambiente encontrado em Votuporanga, embora neste local, o desenvolvimento de patógenos nas sementes tenha sido desfavorecido em comparação à Campinas.

Na semeadura tardia, efetuada em março/abril $\left(\mathrm{S}_{2}\right)$, as condições do ambiente verificadas em Campinas proporcionaram maior duração do período vegetativo para os cultivares precoces de soja estudados, resultando em maior desenvolvimento das plantas e, conseqüentemente, em maior produção de sementes viáveis em comparação à Votuporanga, embora as condições de clima seco e de baixas temperaturas, 
observadas nesta época, tenham favorecido a obtenção de sementes de boa qualidade fisiológica e sanitária nas duas regiões.

$$
\text { Comparando-se épocas de semeadura, }
$$

constatou-se que a produção de sementes viáveis dos cultivares estudados, de modo geral, foi significativamente superior em $\mathrm{S}_{1}$, nas duas localidades estudadas, quando a avaliação da qualidade fisiológica das sementes foi conduzida após a colheita (E1).

Na ocasião da semeadura da safra seguinte (E2), as diferenças entre as qualidades de sementes viáveis obtidas nas duas épocas $\left(S_{1}\right.$ e $\left.S_{2}\right)$ reduziram-se, tornando-se não significativas estatisticamente na maioria das situações.

Assim, considera-se' que houve vantagem quanto à produção de sementes na época tardia $\left(S_{2}\right)$, principalmente, para os cultivares 'IAC-Foscarin-31', 'BR4' e IAS-5 em Campinas e para todos os cultivares em Votuporanga.

Em Campinas, as sementes dos cultivares ' IAC-Foscarin-31' e 'BR-4' não teriam sido aprovadas pelos padrões de sementes básicas e certificadas (SÃO PAULO, 1993), por apresentarem níveis de sementes com mancha púrpura superiores a 5\%. As sementes do cultivar IAS-5, quando avaliadas após o armazenamento (E2), também não teriam sido aceitas, por apresentarem média de germinação inferior a $85 \%$ 
Em Votuporanga, na avaliação efetuada em E1, apenas as sementes dos cultivares 'IAC-Foscarin-31' e 'BR4' teriam sido aprovadas de acordo com os mesmos padrões. As sementes dos cultivares 'IAC-100', 'IAC-16' e 'IAS-5' não atingiram a germinação mínima de $85 \%$. Na avaliação realizada em $\mathrm{E} 2$, as sementes de todos os cultivares teriam sido recusadas pelo mesmo motivo.

Por outro lado, as sementes de todos os cultivares produzidas em Campinas ou Votuporanga na semeadura tardia $\left(S_{2}\right)$ atenderam aos padrões de sementes básicas e certificadas vigentes em 1993 no Estado de São Paulo. Ainda, sementes colhidas em $S_{1}$ passaram por dois períodos de temperatura e umidade relativa do ar elevadas até a época da semeadura seguinte (E2): no início do período de armazenamento (março-abril) e no final (setembro a novembro). As sementes obtidas em $\mathrm{S}_{2}$ foram armaz!nadas. após a colheita em condições de temperatura e unnidade relativa do ar mais favoráveis à conservação das sementes; apenas durante a fase final do armazenamento (setembro a novembro), foram submetidas à temperaturas e umidade relativas do ar em elevação.

Assim, o periodo mais curto compreendido entre a colheita e a semeadura da safra seguinte, quando se empregou a semeadura tardia, representou maior garantia de manutenção da qualidade fisiológica, além de ter reduzido as chances do desenvolvimento prejudicial de fungos de armazenamento nas sementes, principalmente, os do gênero Aspergillus, até a data do plantio. 
Pelo exposto, verifica-se que, apesar de a semeadura tardia $\left(S_{2}\right)$ ter reduzido consideravelmente a produtividade dos cultivares de soja nas duas regiões estudadas, os resultados obtidos nesta pesquisa revelaram que o cultivo da soja na. entre-safra com semeadura em março/abril e irrigação suplementar permitiu a obtenção de um somatório maior dos atributos que caracterizam uma semente de boa qualidade.

Este procedimento mostrou-se uma boa opção, principalmente, para regiões como a de Votuporanga, onde a semeadura na época convencional pode inviabilizar a produção de sementes dos cultivares precoces de soja.

Ainda; alternativas como aumento da densidade de plantas, redução do espaçamento entre linhas e adubações nitrogenadas, visando inçrementar 0 desenvol.vimento das plantas e, conseqüentemente, a produção de sementes quando a semeadura é realizada tardiamente, em março/abril, merecem ser avaliadas. 


\section{CONCLUSÕES}

A análise dos dados e a interpretação dos resultados obtidos na presente pesquisa permitiram as seguintes conclusões:

5.1. $O$ retardamento da semeadura de cultivares precoces de soja para o final do verão/início do outono, associado à condução da cultura sob irrigação suplementar, constitui-se alternativa viável para a produção de semente:s de melhor qualidade;

5.2. a redução da produtividade da cultura, resultante de retardamento da época de semeadura, é compensada pela maior possibilidade de obtenção de sementes de cultivares precoces de soja de melhor qualidade fisiológica e sanitária;

5.3. a adoção de retardamento da semeadura, na produção de sementes de cultivares precoces de soja, deve ser baseada na análise tanto da produção total como na de sementes viáveis, considerando-se a época de avaliação da qualidade das sementes; 
5.4. as diferenças de qualidade das sementes são determinadas pelos efeitos de temperatura, umidade relativa do ar e patógenos predominantes em cada época e local, no período que coincide com a maturação e colheita das sementes. 


\section{REF́ERÊNCIAS BIBLIOGRÁFICAS}

ABEL, G.H. Response of soybeans to dates of planting in the Imperial Valley of California. Agronomy Journal, 53 (2) : 95-98, 1961 .

ABNEY, T.S. \& PLOPER, L.D. Growth regulators effects on soybean seed maturation and seedborne fungi. Plant Disease, 5(6):585-589, 1991.

ANDREWS, C.H. Preharvest environment: weathering. In: SINCLAIR, J.B. \& JACKOBS, J.A. ed. Soybean seed quality and stand establishment. INTSOY n.22, 1982, 19-25. ATHAYDE, M.L.F.; RODRIGUES, R.; ARF.O. Comportamento de cultivares de soja em semeadura tardia na região de Jaboticabal (SP). In: SEMINÁRIO NACIONAL DE PESQUISA DE SOJA, 3., Campinas, 1984. Anais. Londrina, EMBRAPACNPSo, 1984. p.441-448.

ATHOW, K.L. \& LAVIOLETTE, F.A. Pod protection effects on soybean seed germination and infection with Diaporthe phaseolorum var. sojae and other microrganisms. Phytopathology, 63(8):1021-1023, 1973.

BAKER, K.F. Seed Pathology. In: KOZLOWSKI, T.T., ed. Seed Biology. New York, Academic Press, 1972. p.317-416. 
BALDUCCHI, A.J. \& MCGEE, D.C. Environmental factors influencing infection of soybean seed by Phomopsis and Diaporthe species during seed maturation. Plant Disease, $71(3): 209-212,1987$.

BARNI, N.A.; BERGAMASCHI, H.; GOMES, J.E.S. Época de semeadura e cultivares de soja para o Rio Grande do Sul. IPAGRO Informa, 21:67-70, 1978.

BERGAMASCHI, H.; BERLATO, M.A.; WESTPHALEM, S.L. Épocas de semeadura de soja no Rio Grande do Sul: avaliação e interpretação dos ensaios ecológicos de soja. IPAGRO Informa, 18:7-14, 1977.

BERLATO, M.A. \& BERGAMASChI, H. Consumo de água da soja. I. Evapotranspiração estacional em ótimas condições de disponibilidade de água no solo.' In: SEMINÁRIO NACIONAL DE PES@UISA DA SOJA, 1., Londrina, 1978. Anais. Londrina, EMBRAPA, 1978.

BOARD, J.E. Yield components related to seed yield in determinate soybean. Crop Science, 27:1296-1297, 1987. BOARD, J.E. \& HALL, W. Premature flowering in soybean yield reductions at nonoptimal planting dates as influenced by temperature and photoperiod. Agronomy Journal, 76:700704,1984 .

BOARD, J.E. \& SETTIMI, R. Photoperiod effect before and after flowering on branch development in determinate soybean. Agronomy Journal, 78:995-1002, 1986. 
BOLKAN, H.A.; SILVA, A.R. de; CUPERTINO, F.P. Fungi associated with soybean and bean seeds and their control in Central Brazil. Plant Disease Reporter, 60(6):545$548,1976$.

BRASIL, Ministério da Agricultura. Regras para análise de sementes. Brasília, Departamento Nacional de Produção Vegetal, 1976. 182p.

BUENO, L.C.S.; SEDIYAMA, C.S.; VIEIRA, C. Efeitos do espaçamento, densidade e época de plantio sobre duas variedades de soja. Experientiae, 20(10):263-287, 1975. CARRARO, I.M.; BEGO, A.; ROCHA, A. Efeito do retardamento da colheita sobre a qualidade de sementes de soja em Palotina, PR. Revista Brasileira de Sementes, $7(3)$ :123132, 1985.

CARTER, O.G. Detailed yield analysis of the effect of different planting dates on seven soybean varieties. Iowa State Journal of Research, 48(4):291-310, 1974. CARTTER, J.L. \& HARTWIG, E.E. The management of soybeans. Advances in Agronomy, 14:359-412, 1962.

CAVINESS, C.E. Environmental effects on soybean seed quality. In: SOYBEAN SEED RESEARCH CONFERENCE, 8., Chicago, 1978. Proceedings. American Seed Trade Association, 1978. p. 79-85. 
CHRISTENSEN, C.M. Loss of viability in storage: microflora. Seed Science \& Technology, 1:547-562, 1973. COSTA, A.V.; MONTEIRO, P.M.F.O.; JARDIM, P.M. Épocas de plantio e seus efeitos sobre algumas características agronômicas da soja, no Cerrado de Goiânia. In: SEMINÁRIO NACIONAL DE PESQUISA DA SOJA, 1., Londrina, 1979. Anais. Londrina, EMBRAPA-CNPSo, 1979. p. 131-138. COSTA, A.V.; MONTEIRO, P.M.F.O.; ROLIM, R.B.; MORAES, E.A.; VILELA, L. A altitude na qualidade de semente de soja produzida no Estado de Goiás e Distrito Federal. In: SEMINÁRIO NACIONAL DE PESQUISA DE SOJA, 3., Campinas, 1984. Anais. Londrina, EMBRAPA-CNPSo, 1984. p. 944-951. COSTA, A.V.; ROLIM, R.B.; MONTEIRO, P.M.F. de; NUNES JÚNIOR, J.; ZANINI JÚNIOR, A. Indicação de regiões climáticas favoráveis à produção de sementes de soja no Estado de Goiás. Circular Técnica. EMGOPA, Goiânia, n. 14, 1988. 25p.

COSTA, A.V.; SEDIYAMA, T.; SILVA, R.F. da; SEDIYAMA, C.S.; FONTES, L.A.N.; GOMES, J.L.L.; ROLIM, R.B.; MONTEIRO, P.M.F. de O. Alguns fatores que afetam a qualidade fisiológica da semente de soja. Documentos. EMGOPA, Goiânia, n.2, 1987a. 48p.

COSTA, N.P. da; FRANÇA NETO, J. de B.; PEREIRA, L.A.G.; HENNING, A.A. Avaliação da qualidade da semente de soja produzida no Estado do Paraná. Comunicado técnico. EMBRAPA-CNPSO, LONDRINA, n.36, 1986. 13p. 
COSTA, N.P. da; FRANÇA NETO, J. DE B.; PEREIRA, L.A.G.; HENNING, A.A. Avaliação da qualidade da semente de soja produzida no Estado do Paraná. Pesquisa Agropecuária Brasileira, $22(11 / 12): 1157-1165,1987 b$.

DASSOU, S. \& KUENEMAN, E.A. Screening methodology for resistance to field weathering of soybean seed. Crop Science, 24:774-779, 1984 .

DHINGRA, O.D. Internally seed borne Fusarium semitectum and Phomopsis sp. affecting dry and snap bean seed quality. Plant Disease Reporter, 62:509-512, 1978.

DHINGRA, O.D.; GARCIA, A.; SEDIYAMA, T. Effect of planting time on seed infection by Phomopsis sojae in ten soybean cultivars. Fitopatologia Brasileira, 4:435-440, 1979a. DHINGRA, O.D.; SEDIYAMA, C.; CARRARO, I.M.; REIS, M.S . Behavior of four soybean cultivars to seed infecting fungi in delayed harvest. Fitopatologia Brasileira, $3: 277-282,1978$.

DHINGRA, O.D.; SEDIYAMA, T; SEDIYAMA, T. Effect of planting and harvest time on seed infection of soybean by Phomopsis sojae and Fusarium semitectum. Fitopatologia Brasileira, 4:467-472, $1979 b$.

DIMMOCK, F. \& WARREN, F.S. The influence of time of planting on the yield and composition of soybean seed. Canadian Journal of Agricultural Science, 33 (5):550-558, 1953. 
DOSS, B.D.; PEARSON, R.W.; ROGERS, H.T. Effect of soil water stress at various growth stages on soybean yield. Agronomy Journal, 66(2):297-299, 1974.

ELLIS, M.A.; MACHADO, C.C.; PRASARTSEE, C.; SINCLAIR, J.B. Ocurrence of Diaporthe phaseolorum var. sojae (Phomopsis $\mathrm{sp)}$ in various soybean seedlots. Plant Disease Reporter, $58(2): 173-176,1974$.

FALIVENE, S.M.P.; MIRANDA, M.A.C. de; ALMEIDA, L.D. de. Temperatura e ocorrência de necrose dos cotilédones em soja. Revista Brasileira de Sementes, 2(1):43-51, 1980. FEASTER, C.V. Influence of planting date on yield and other characteristics of soybeans grown in Southeast Missouri. Agronomy Journal, $41(2)$ :57-67, 1949.

FEHR, W.R. \& CAVINESS, C.E. Stage of soybean development. Ames, Iowa State University, 1977. 11p.

FERREIRA, L.P.; JJEFMAN, P.S.; ALMEIDA, A.M.R. Descrição e controle das principais moléstias. In: MIYASAKA, S. \& MEDINA, J.C., ed. A Soja no Brasil, 1981. p. 603-627. FRANÇA NETO, J.B.; COSTA, N.P.; HENNING, A.A.; ALMEIDA, A.M.R.; BARRETO, J.N. Efeito da aplicação de fungicidas foliares sobre a maturação fisiológica de sementes de soja. In: SEMINÁRIO NACIONAL DE SOJA, 3., Campinas, 1984. Anais. Londrina, EMBRAPA-CNPSo, 1984. p. 10341055 .

FRANÇA NETO, J. de B.; PEREIRA, L.A.G.; COSTA, N.P. da; KRZYZANOWSKI, F.C.; HENNING, A.A. Metodologia do teste de tetrazólio em sementes de soja. Documentos. EMBRAPACNPSo, Londrina, n. 32, 1988. 60p. 
FRANÇA NETO, J.B. \& WEST, S.H. Problems in evaluating viability of soybean seed infected with Phomopsis spp Journal of Seed Tecnology, 13(2):122-135, 1989a.

FRANÇA NETO, J.B. \& WEST, S.H. Effects of Colletrotichum truncatum and Cercospora kikuchii on viability and quality of soybean seed. Journal of Seed Technology, $13(2): 136-144,1989 b$.

FULCO, W.S.; LEHMAN, P.S.; CRESPO, A.T. Época de colheita da soja (Glycine max (L.) Merrill) como fator de qualidade de semente. Fitopatologia Brasileira, 4:25-40, 1979 .

GAZZONI, D.; OLIVEIRA, E.B. de; CORSO, I.C.; FERREIRA, B.S.C.; BOAS, G.L.V.; MOSCARDI, F.; PANIZZI, A.R. Manejo de pragas da soja. Circular Técnica. EMBRAPA-CNPSo, Londrina, n. 5, 1981. 44p.

GOULART, A.C.P.; MACHADO, J.C.; VIEIRA, M.G.G.C.; PITTIS, J.E. Desenvolvimento inicial da soja (Glycine max) a partir de sementes portadoras de Phomopsis sp. em casa de vegetação. Fitopatologia Brasileira, 15(1):99-101, 1990 .

GRAVES, C.R.; OVERTON, J.R.; MORGHAN, H. SOybean variety. Date of planting study from 1974-76. Bulletin. The University of Tennessee Agricul tural Experiment Station, Knoxville, n. 582, 1978. 51p.

GREEN, D.E.; PINNELL, E.L.; CAVANAH, L.E.; WILLIAMS, L.F. Effect of planting date and maturity date on soybean seed quality. Agronomy Journal, 57(1):165-168, 1965. 
HANWAY, J.J. \& THOMPSON, H.E. HOW a soybean plant develops. Special Reporter. Ames, Iowa State University, n. 53, 1971. 17p.

HARRINGTON, J.F. Seed storage and longevity. In: KOZLOWSKI, T.T., ed. Seed Biology, Germination Control, Metabolism and Patholology. New York, Academic Press, 1972. V.3, p. 145-245.

HARTWIG, E.E. Factors affecting time of planting soybeans in the Southern States. Circular. United States Department of Agriculture, Washington, D.C., n. 943, 1954. 13p.

HENNING, A.A. Testes de sanidade de sementes de soja. In: SOAVE, J. \& WETZEL, M.M.V. da S., ed. Patologia de Sementes. Campinas, Fundação Cargill, 1987. p. 441-454. HENNING, A.A. \& ERANÇA NETO, J. de B. Problemas na avaliação da germinação de sementes de soja con alta incidência de Phomopsis sp. Revista Brasileira de Sementes, 2(3):9-22, 1980.

HEPPERLY, P.R. \& SINCLAIR, J.B. Associations of plant synptoms and pod position with Phomopsis sojae seed infection and damage in soybean. Crop Science, $20(3): 379-381,1980$.

HEPPERLY, P.R. \& SINCLAIR, J.B. Relationships among Cercospora kikuchii, other seed mycoflora, and germination of soybeans in Puerto Rico and Illinois. Plant Disease, 65:130-132, 1981.

HILL, H.J. \& WEST, S.H. Fungal penetration of soybean seed through pores. Crop Science, 22(3):602-605, 1982. 
HOOGENBOOM, G.; PETERSON, C.M.; HUCK, M.G. Shoot growth rate of soybean as affected by drought stress. Agronomy Journal. 79:598-607. 1987.

HOWELL, R.W.; COLLINS, F.J.; SEDGWICK,V.E. Respiration of soybean seeds as related to weathering losses during ripening. Agronomy Journal, 51 (11):677-679, 1959.

JARDINE, D.J. The Iowa soybean pod test for predicting Phomopsis seed decay in Kansas. Plant Disease, $75(5): 523-525,1991$.

JOHNSON, R. Crop Management. In: WILCOX, J.R. ed. SOYBEANS: improvement, production and uses. 2ed. Madison, American Society of Agronomy, Inc., Crop Science Society of America, Inc., Soil Science Society of America, 1987, p. 355-390.

JORDAN, E.G.; MANANDHAR, J.B.; THAPLIYAL, P.N.; SINCLAIR, J.B. Soybean seed quality of 16 cultivars and four maturity groups in Illinois. Plant Disease, 72(1):64$67,1988$.

KEIGLEY, P.J. \& MULLEN, R.E. Changes in soybean seed quality from high temperature during seed fill and maturation. Crop Science, 26:1212-1216, 1986.

KILPATRICK, R.A. Fungi associated with the flowers, pods, and seeds of soybeans. Phytopathology, 47:131-135, 1957 .

KILPATRICK, R.A. \& HARTWIG, E.E. Effect of planting date on incidence of fungus infection of Ogden soybean seeds grown at Walnut Hill, Florida. Plant Disease Reporter, $39(2): 174-176,1955$. 
KULICK, M.M. \& YAKLICH, R.W. Soybean seed coat structures: relationship to weathering resistance and infection by the fungus Phomopsis phaseoli. Crop Science, 31:108-113, 1991.

KUNWAR, I.K.; MANANDHAR, J.B.; SINCLAIR, J.B. Histopathology of soybean seeds infected with Alternaria alternata. Phytopathology, 76(5):543-546, 1986.

LAZZARI, A. \& MERONUCK, R.A. Dry matter losses caused by storage fungi on soybean seeds. Phytopathology, $78(12): 1553,1988$.

LOEFFLER, T.M.; TeKRONY, D.M.; EGLI, D.B. The bulk conductivity test as an indicator of soybean seed quality. Journal of Seed Technology, 12(1):37-53, 1988. MAJOR, D.J.; JOHNSON, D.R.; TANNER, J.W.; ANDERSON, I.C. Effects of daylength and temperature on soybean development. Crop Science, 15(1):174-179, 1975.

MARCANO, A.R. \& SINCLAIR, J.B. Fruiting structures of Colletrotichum dematium var. truncata and Phomopsis sojae formed in soybean seeds. Plant Disease Reporter, $62(10): 873-876,1978$.

MARCOS FILHO, J. Qualidade fisiológica e maturação de sementes de soja (Glycine max (L.) Merrill). Piracicaba, 1979. 180p. (Doutorado-Escola Superior de Agricultura "Luiz de Queiroz"/USP).

MARCOS FILHO, J. Produção de sementes de soja. Campinas, Fundação Cargill, 1986. 86p. 
MARCOS FILHO, J.; CARVALHO, R.V. de; CÍCERO, S.M.; DEMÉTRIO, C.G.B. Qualidade fisiológica e comportamento de sementes de soja (Glycine max (L.) Merrill) no armazenamento e no campo. Anais da Escola Superior de Agricultura Luiz de Queiroz, XLII:195-249, 1985.

MARCOS FILHO, J. \& NOVEMBER, A.D.L.C. Características agronômicas e fenologia da soja (Glycine max (L.) Merrill) sob influência da época de semeadura. Piracicaba, 1990. 58p. (não publicado) .

MARCOS FILHO, J. \& VINHA, J.L. Teor de umidade da semente, condições de armazenamento e comportamento da soja (Glycine $\max ($ L.) Merrill) no teste de envelhecimento

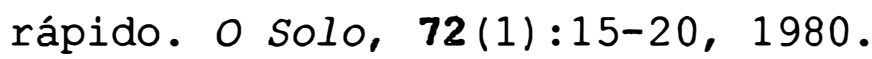

MASCARENHAS, H.A.A. \& MIYASAKA, S. Instruções para a cultura da soja. Boletim Técnico. IÁC, CAMPINAS, N. 22, 1968. 48p.

MATSON, A.L. Some factors affecting yield response of soybeans to irrigation. Agronomy Journal, $56(6)$ :552-555, 1964 .

MILANEZ, D.; FONSECA, W.F.; PACOVA, B.E.V. Pesquisa e experimentação com soja (Glycine max (L.) Merrill) no Estado do Espírito Santo. II. Estudo de época de plantio. Revista Ceres, $25(137): 36-41,1978$.

MIRANDA, M.A.C. de; MIYASAKA, S.; MASCARENHAS, H.A.A. Melhoramento da soja no Estado de São Paulo. In: A Soja no Brasil Central. 2. ed. Campinas, Fundação Cargill, 1982, p.77-105. 
MONDRAGON, R.L. \& POTTS, H.C. Field deterioration of soybean as affected by environment. Proceedings of the Association of Official Seed Analysts, 64:63-71, 1974. MOORE , R.P. Tetrazolium as a universally acceptable quality test of viable seed. Proceedings of the International Seed Testing Association, 27:795-805, 1962 .

MOORE, R.P. Mechanisms of water damage in mature soybean seed. Proceedings of the Association of Official seed Analysts, 61:112-118, 1971 .

MOTA, F.S. da. Condições climáticas e produção de soja no Sul do Brasil. In: VERNETTI, F.J. ed. Soja: Planta, clima, pragas e moléstias invasoras. Campinas, Fundação Cargill, 1983. p. 93-124.

NAKAGAWA, J.; MACHADO, J.R.; ROSOLEM, C.A. Efeito da densidade de plantas e da época de semeadura na produção e qualidade de sementes de soja. Revista Brasileira de Sementes, 8 (3):99-112, 1986.

NAKAGAWA, J.; ROSOLEM, C.A.; MACHADO, J.R. Épocas de semeadura da soja. 1. Efeitos na produção de grãos e nos componentes da produção. Pesquisa Agropecuária Brasileira, 18(11):1187-1198, 1983.

NAKAGAWA, J.; ROSOLEM, C.A.; MACHADO, J.R. Efeito da época de semeadura na qualidade de sementes de três cultivares de soja, em Botucatu-SP. Revista Brasileira de Sementes, $6(1): 25-38,1984 a$. 
NAKAGAWA, J.; ROSOLEM, C.A.; MACHADO, J.R. Desempenho de sementes de soja originárias de culturas estabelecidas em diferentes épocas. Revista Brasileira de Sementes, $6(3): 61-76,1984 b$.

NANGJU, D. Seed characters and germination in soybean. Experimental Agriculture, 15(4):385-392, 1979.

NICHOLSON, J.F. \& SINCLAIR, J.B. Effect of planting date, storage conditions and seedborne fungi on soybean seed quality. Plant Disease Reporter, 57(9):775, 1973.

NOGUEIRA, S.S.S.; MIRANDA, M.A.C.; HAAG, H.P.; NAGAI, V.

Efeito da época de semeadura na duração dos períodos vegetativo e reprodutivo e nas produções dos cultivares de soja UFV-1 e IAC-7. In: SEMINÁRIO NACIONAL DE PESQUISA DE SOJA, 3., CAMPINAS, 1984. Anais. Londrina, EMBRAPA-..ClYPSO, 1984 . p. 33-44.

OSLER, R.D. \& CARTTER, J.L. Effect of planting date on chemical composition and growth characteristics of soybeans. Agronomy Journal, 46(6):267-270, 1954.

OSORIO, J.A. \& MCGEE, D.C. Effects of freeze damage on soybean seed mycoflora and germination. Plant Disease, $76(9): 879-882,1992$.

PANIZZI, A.R.; FERREIRA, B.S.C.; NEUMAIER, N.; QUEIROZ, E.F. de. Efeitos da época de semeadura e do espaçamento entre fileiras na população de artrópodos associados à soja, 1., Londrina, Anais. Londrina, EMBRAPA-CNPSo, 1978. p.113-131. 
PAOLINELLI, G.P.; TANAKA, M.A.S.; ARANTES, N.E. Germinação e vigor de sementes de soja produzidas nas safras 1980/81 e 1981/82 em Minas Gerais. In: SEMINÁRIO NACIONAL DE PESQUISA DE SOJA, 3., Campinas, 1984 Anais. Londrina, EMBRAPA-CNPSo, 1984a. 975-983.

PAOLINELLI, G. de P.; TANAKA, M.A. de S.; REZENDE, A.M. de. Influência da época de semeadura sobre a qualidade fisiológica e sanitária de sementes de soja. Revista Brasileira de Sementes, 6 (1):39-50, 1984b.

PATHAN, M.A.; SINCLAIR, J.B.; MCCLARY, R.D. Effects of Cercospora kikuchii on soybean seed germination and quality. Plant Disease, 73(9):720-723, 1989.

PAYNE, R.C.; MORRIS, L.F.; KOSZYKOWSKI, T.J. de; NOBEL, P.M.; FAUL, K. The effect. of planting date on the expression of some scybean growth characteristics. The NewsLetter of the AOSA, $\mathbf{5 2}(2): 36-40,1978$.

PEREIRA, L.A.G.; COSTA, N.P. da; QUEIROZ, E.F. de; NEUMAIER, N.; TORRES, E. Efeito da época de semeadura sobre a qualidade de sementes de soja. Revista Brasileira de Sementes, 1(3):77-89, 1979.

PETTERSON, J.L. \& STRELECKI, R.F. The effect of Diaporthe phaseolorum on soybean germination and growth in New Jersey, Plant Disease Reporter, 49(3):228-229, 1965. PLOPER, L.D.; ABNEY, T.S.; ROY, K.W. Influence of soybean genotype on rate of seed maturation and its impact on seedborne fungi. Plant Disease, 76(3):287-292, 1992. 
QUEIROZ, E.F. de; NEUMAIER, N.; TORRES, E.; PEREIRA, L.A.G.; BIANCHETTI, A.; TERAZAWA, F., PALHANO, J.B.; YAMASHITA, J. Recomendações técnicas para a colheita mecânica. In: MIYASAKA, S. \& MEDINA, J.C. ed. A Soja no Brasil, Campinas, ITAL, 1981. p. 701-710.

RASSINI, J.B. \& LIN, S.S. Efeito de períodos de estiagens artificiais durante estádios de desenvolvimento da planta no rendimento e qualidade da semente de soja (Glycine max (L.) Merrill). Agronomia Sulriograndense, $17(2): 225-237,1981$.

ROSS, J.P. Effect of overhead irrigation and Benomyl sprays on late-season foliar diseases, seed-infection and yields of soybean. Plant Disease Reporter, 59(10):809813, 1975.

RUPE, J.C. \& FERRISS, R.S. Effects of pod moisture on soybean seed infection by Phomopsis sp. Phytopathology, $76(3): 273-277,1986$.

RUSSIN, J.S.; ORR, D.B.; LAYTON, M.B.; BOETHEL, D.J. Incidence of microorganisms in soybean seeds damaged by stink bug feeding. Phytopathology, 78(3):306-310, 1988. SANCHEZ, A.L. \& YUYAMA, K. Época de plantio na cultura de soja (Glycine max (L.) Merrill), cultivares 'Santa Rosa' e 'Viçoja' em Jaboticabal, S.P. Científica, 7(2):225234,1979 . 
SÃo PAULO, Secretaria da Agricultura e Abastecimento. Características dos cultivares multiplicados pelo Departamento de Sementes, Mudas e Matrizes da Coordenadoria de Assistência Técnica Integral. Campinas, 1990. $47 \mathrm{p}$.

SÃO PAULO, Secretaria da Agricultura e Abastecimento. Padrões de sementes produzidas pelo Departamento de Sementes, Mudas e Matrizes da Coordenadoria de Assitência Técnica Integral. Campinas, 1993. 12p. SAS Statistical Analysis Sistem, 1993. 192p. SCHUH, $\boldsymbol{\omega}$. Effect of pod development stage, temperature, and pod wetness duration on the incidence of purple seed stain of soybeans. Phytopathology, 82:446-451, 1992. SHANMUGASUNDARAM, S. \& TSOU, S.C.S. Photoperiod and critical duration for flower induction in soybean. Crop Science, 18(4):598-601, 1978 .

SHORTT, B.J.; GRYBAUSKAS, A.P.; TENNE, F.D.; SINCLAIR, J.B. Epidemiology of Phomopsis seed decay of soybean in Illinois. Plant Disease, $65(1): 62-64,1981$.

SILVA, C.M. da; MESQUITA, A.N. de; PEREIRA, L.A.G. Efeito da época de colheita na qualidade da semente de soja. Revista Brasileira de Sementes, 1(2):41-48, 1979. SINCLAIR, J.B., ed., Compendium of soybean diseases. 2. ed. St. Paul, The American Phytopathological Society, 1982. $104 \mathrm{p}$.

SINCLAIR, J.B. Latent infection of soybean plants and seed by fungi. Plant Disease, $75(3): 220-224,1991$. 
SINGH, T. \& SINCLAIR, J.B. Histopathology of Cercospora sojina in soybeans. Phytopathology, 75:185-189, 1985. SIONIT, N. \& KRAMER, P.J. Effect of water stress during different stages of growth of soybean. Agronomy Journal, $69(2): 274-277,1977$.

SPILKER, D.A.; SCHMITTHENER, A.F.; ELLETT, C.W. Effects of humidity, temperature, fertility, and cultivar on the reduction of soybean seed quality by Phomopsis sp. Phytopathology, 71(10):1027-1029, 1981.

TACHIBANA, H.; METZER, R.B.; GRABE, D.F. Cotyledon necrosis in soybean. Plant Disease Reporter, 52(6):459-462. 1968 . TANAKA, M.A.S.; PAOLINELLI, G.P.; ARANTES, N.E. Qualidade sanitária de sementes de soja produzidas no Estado de Minas Gerais. In: SEMINÁRIO NACIONAL DE PESQUISA DE SOJA, 3., Campinas, 1984. Anais. Londrina, EMBRAPACNPSo, 1984. p.984-992.

TAO, K.J. An evaluation of alternative methods of accelerated aging seed vigor test for soybeans. Journal of Seed Technology, 3(2):30-40, 1979.

TeKRONY, D.M.; EGLI, D.B.; BALLES, J.; TOMES, L.; STUCKEY, R.E. Effect of date of harvest maturity on soybean seed quality and Phomopsis sp seed infection. Crop Science, $24(1): 189-193,1984$.

TeKRONY, D.M.; EGLI, D.B.; PHILLIPS, A.D. Effect of field weathering on the viability and vigor of soybean seed. Agronomy Journal, $72(5): 1980$. 
TEKRONY, D.M.; EGLI, D.B.; STUCKEY, R.E.; BALLES, J.B. Relationship between weather and soybean seed infection by Phomopsis sp. Phytopathology, 73(6):914-918, 1983. THOMISON, P.R.; JEFFERS, D.L.; SCHMITTHENNER， A.F. Phomopsis seed infection and nutrient accumulation in pods of soybean with reduced fruit loads. Agronomy Journal, 80:55-59, 1988.

TORRIE, J.H. \& BRIGGS, G.M. Effect of planting date on yield and other characteristics of soybeans. Agronomy Journal, $47(5): 210-212,1955$.

TRAGNAGO, J.L. \& BONETTI, L.P. Diferentes épocas de semeadura no rendimento e outras características de alguns cultivares de soja no Rio Grande do Sul. In: SEMINÁRIO NACIONAL DE PESQUISA DE SOJA, 3.; Campinas, 1984. Anais. Londrina, EMB:RAPA-CNPSo, 1984. p.57-69. VAN RAIJ, B.; SILVA, N.M. da; BATAGLIA, O.C.; QUAGGIO, J.A.; HIROCE, R.; CANTARELLA, H.; BELLINAZI JUNIOR, R.; DECHEN, A.R.; TRANI, P.E. Recomendações de adubação e calagem para o Estado de São Paulo. Boletim Técnico. IAC, Campinas, n.100, 1985. 107p.

VAUGHAN, D.A.; BERNARD, R.L.; SINCLAIR, J.B. Soybean seed quality in relation to days between development stages. Agronomy Journal, 81 (2) :215-219, 1989.

VAUGHAN, D.A. BERNARD, R.L.; SINCLAIR, J.B.; KUNWAR, I.K. Seed physiology, production, technology. Soybean seed coat development. Crop Science, 27:759-765, 1987. 
VERNETTI, F. de J. Genética da soja: Caracteres qualitativos. In: VERNETTI, F.J., ed. Soja: Genética e melhoramento. Campinas, Fundação Cargill, 1983. p.93124.

WALLEN, V.R. \& CUDDY, T.F. Relation of seed-borne Diaporthe phaseolorum to the germination of soybeans. Proceedings of the Association of Official Seed Analysts, $50(1): 137-$ $140,1960$.

WANG, S.R. \& WANG, G.M. Resistência à seca. In: EMBRAPA. Resultados de Pesquisa de Soja 1977/78, 1978. p. 66-74. WESTGATE, M.E. \& GRANT, T. Effect of water deficits on seed development in soybean. Plant Physiology, 91:975-979, 1989.

WESTGATE, M.E.; SCHUSSLER, J.R.; REICOSKY, D.C.; BREINNER, M.L. Effect of water deficits on seed development in soybean. II. Conservation of seed growth rate. Plant Physiology, 91:980-985, 1989.

WETZEL, M.M.V.S. Fungos de armazenamento. In: SOAVE, J. \& WETZEL, M.M.V. da., ed. Patologia de Sementes. Campinas, Fundação Cargill, 1987. p. 260-275.

WHIGHAM, D.K. \& MINOR, H.C. Agronomic characteristics and environmental stress. In: NORMAN, A.G., ed. The Soybeans. Physiology, Agronomy and Utilization. New York, Academic Press, 1967. p.78-105. 
WILCOX, J.R.; ABNEY, T.S.; FRANKENBERGER, E.M. Relationships between seedborne fungi and altered photoperiod. Phytopathology, 75(7):797-800, 1985. YORINORI, J.T. Fatores que afetam os resultados dos testes de sanidade envolvendo incubação. In: SOAVE, J. \& WETZEL, M.M.V. da S., ed. Patologia de Sementes. Campinas, Fundação Cargill, 1987. p. 299-312. 